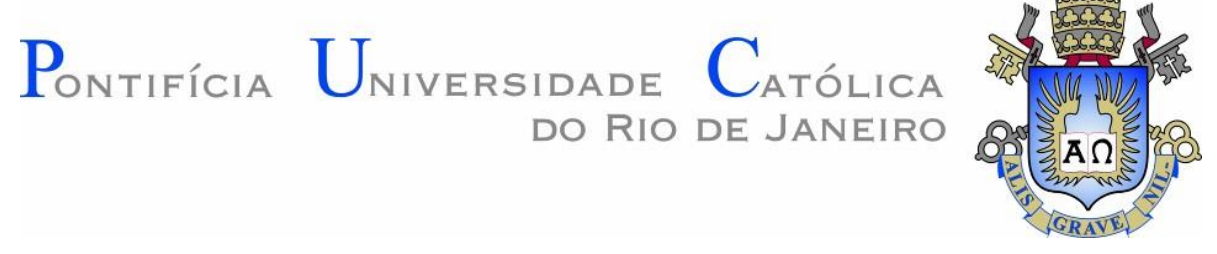

Luísa Gomes de Almeida Vilardi

Gestores escolares e sistemas de administração e avaliação em Minas Gerais: uma proposta de modelo de análise do uso de dados

Tese apresentada como requisito parcial para obtenção do grau de Doutora em Educação pelo Programa de Pós-graduação em Educação, do Departamento de Educação da PUC-Rio.

Orientadora: $\operatorname{Prof}^{\mathrm{a}}{ }^{\mathrm{D}}{ }^{\mathrm{a}} \mathrm{a}$ Cynthia Paes de Carvalho

Rio de Janeiro, fevereiro de 2021. 
Gestores escolares e sistemas de administração e avaliação em Minas Gerais: uma proposta de modelo de análise do uso de dados

Tese apresentada como requisito parcial para obtenção do grau de Doutor pelo Programa de Pós-graduação em Educação do Departamento de Educação do Centro de Teologia e Ciências Humanas da PUC-Rio. Aprovada pela Comissão Examinadora abaixo assinada.

\author{
Prof?. Cynthia Paes de Carvalho \\ Orientadora \\ PUC-Rio \\ Profa . Ana Cristina Prado de Oliveira \\ UNIRIO \\ Prof ${ }^{a}$. Mariane Campelo Koslinski \\ UFRJ \\ Profa. Alicia Maria Catalano de Bonamino \\ PUC-Rio
}

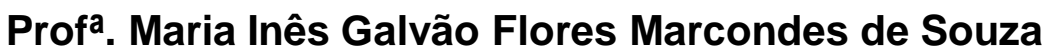

PUC-Rio

Prof ${ }^{a}$. Silvina Julia Fernández

UFRJ

Rio de Janeiro, 26 de fevereiro de 2021. 
Todos os direitos reservados. A reprodução, total ou parcial, do trabalho é proibida sem autorização da universidade, da autora e da orientadora.

\section{Luísa Gomes de Almeida Vilardi}

Possui mestrado em Educação em Ciências e Saúde pela UFRJ, graduou-se em licenciatura em Pedagogia (Faculdade Estácio de Sá) e em Ciências Biológicas (Universidade Federal de Juiz de Fora). Atua profissionalmente, desde 2013, no Mestrado Profissional em Gestão e Avaliação da Educação Pública (PPGP/CAEd/UFJF). Tem interesse em pesquisas sobre gestão escolar, uso de dados educacionais, políticas públicas e liderança do diretor.

Ficha Catalográfica

Vilardi, Luísa Gomes de Almeida

Gestores escolares e sistemas de administração e avaliação em Minas Gerais : uma proposta de modelo de análise do uso de dados / Luísa Gomes de Almeida Vilardi ; orientadora: Cynthia Paes de Carvalho. -2021.

149 f. : il. color. ; $30 \mathrm{~cm}$

Tese (doutorado)-Pontifícia Universidade Católica do Rio de Janeiro, Departamento de Educação, 2021.

Inclui bibliografia

1. Educação - Teses. 2. Uso de dados educacionais. 3. Contexto organizacional. 4. Liderança do diretor. 5. Clima escolar. 6. Confiança nos dados. I. Carvalho, Cynthia Paes de. II. Pontifícia Universidade Católica do Rio de Janeiro. Departamento de Educação. III. Título. 
Dedico esta pesquisa à todos os gestores de escolas públicas que cotidianamente precisam gerenciar inúmeros dados educacionais com o objetivo de ofertar uma educação de qualidade e com equidade. 


\section{Agradecimentos}

Esta tese é fruto de inúmeras discussões e vivências que permearam anos de prática profissional e estudos. Por conta disso, é necessário agradecer as pessoas que fizeram parte desta trajetória.

À minha família, ao Leo e a Sofia por compreenderem as minhas ausências e terem me dado o suporte necessário para que eu pudesse viajar toda semana para o PUCRio para cursar o Doutorado.

À minha orientadora, prof ${ }^{\mathrm{a}} \operatorname{Dr}^{\mathrm{a}}$. Cynthia Paes de Carvalho por, dentre tantos aprendizados, ter me ensinado a importância do diálogo entre a pesquisa acadêmica e o que acontece nas escolas e, principalmente, por ter me ensinado a ser pesquisadora, através do exemplo de construção de uma prática profissional pautada na generosidade e na construção de parcerias e de redes de pesquisa.

Às professoras Dr ${ }^{\mathrm{a}}$. Alícia Bonamino, Dr ${ }^{\mathrm{a}}$. Ana Cristina Prado de Oliveira, Dr ${ }^{\mathrm{a}}$. Maria Inês de Souza, Dra. Mariane Koslinsky, a Dra . Naira Muylaerte e a Dra Silvina Fernandes pelas fundamentais contribuições reflexivas para esta pesquisa.

Ao Centro de Políticas Públicas e Avaliação da Educação da Universidade Federal de Juiz de Fora (CAEd/UFJF) pela liberação semanal para que eu pudesse cursar o Doutorado na PUC-Rio.

Aos meus alunos do PPGP (CAEd/UFJF) que, turma após turma, me ensinam o quão diversa é a educação brasileira e a importância da oferta de uma escola pública, de qualidade e com equidade.

À Secretaria Estadual de Educação de Minas Gerais e a Superintendência Regional de Ensino de Juiz de Fora por terem autorizado esta pesquisa na rede e às escolas por terem me acolhido e permitido que eu experienciasse o cotidiano da vida escolar.

Aos companheiros do GESQ por todas as discussões realizadas. 
À minha da Turma de Doutorado 17.1 pelos encontros anuais maravilhosos, pela nossa união e por termos sempre apoiado uns aos outros. Somos a antítese de muitas turmas da pós-graduação.

O presente trabalho foi realizado com apoio da Coordenação de Aperfeiçoamento de Pessoal de Nível Superior - Brasil (CAPES) - Código de Financiamento 001. 


\section{Resumo}

Vilardi, Luísa Gomes de Almeida; Paes de Carvalho, Cynthia. Gestores escolares e sistemas de administração e avaliação em Minas Gerais: uma proposta de modelo de análise do uso de dados. Rio de Janeiro, 2021. 156p. Tese de Doutorado - Departamento de Educação da Pontifícia Universidade Católica do Rio de Janeiro.

A presente tese intitulada Gestores escolares e sistemas de administração e avaliação em Minas Gerais: uma proposta de modelo de análise do uso de dados buscou compreender as diferentes articulações entre os fatores organizacionais e os atores educacionais perante o processo de uso pedagógico dos dados na gestão das escolas. Para tanto, inicialmente, realizamos uma revisão bibliográfica na qual mapeamos sete fatores que influenciam no processo de uso pedagógico dos dados, a saber: o contexto organizacional, os sistemas de gestão, o suporte e acesso à tecnologia, a formação para uso dos dados educacionais, a racionalidade do diretor, o clima escolar e a liderança do diretor. Diante disso, em cada um dos capítulos desta tese discutimos teoricamente cada um desses fatores conjugados com os dados empíricos dos estudos de caso realizados em duas escolas estaduais de Minas Gerais sob a jurisdição da Superintendência Regional de Ensino de Juiz de Fora (MG). Após os processos de análise desenvolvidos durante a pesquisa e a partir da experiência da pesquisadora nas escolas, apresentamos no capítulo final da tese um novo fator a ser agregado como um potencial influenciador no uso de dados para fins pedagógicos na escola: a confiança nos dados. Isso porque o fato de os gestores educacionais confiarem ou não nos dados provenientes dos sistemas de administração e avaliação faz com que os dados educacionais sejam ou não utilizados pedagogicamente na escola. Como resultado final desta tese apresentamos uma proposta de modelo de análise do uso de dados.

\section{Palavras-chave}

Uso de dados educacionais. Contexto organizacional. Liderança do diretor. Clima escolar. Confiança nos dados. 


\section{Abstract}

Vilardi, Luísa Gomes de Almeida; Paes de Carvalho, Cynthia. Gestores escolares e sistemas de administração e avaliação em Minas Gerais: uma proposta de modelo de análise do uso de dados. Rio de Janeiro, 2021. 156p. Tese de Doutorado - Departamento de Educação da Pontifícia Universidade Católica do Rio de Janeiro.

The present thesis entitled School managers and administration and evaluation systems in Minas Gerais: a proposal for a model of analysis of data use sought to understand the different articulations between organizational factors and educational actors before the process of pedagogical data use in the management of data. schools. To this end, initially, we performed a bibliographic review in which we mapped seven factors that influence the process of pedagogical use of data, namely: the organizational context, management systems, support and access to technology, training for the use of educational data, the director's rationality, the school climate and the director's leadership. Therefore, in each of the chapters of this thesis we theoretically discuss each of these factors combined with the empirical data of the case studies carried out in two state schools in Minas Gerais under the jurisdiction of the Regional Teaching Superintendence of Juiz de Fora (MG). After the analysis processes developed during the research and from the experience of the researcher in schools, we present in the final chapter of the thesis a new factor to be added as a potential influencer in the use of data for pedagogical purposes in the school: trust in the data. This is because the fact that the educational managers trust or not the data of the administration and evaluation systems makes the educational data to be used pedagogically in the school. As a final result of this thesis, we present a proposal for a model of analysis of the use of data.

\section{Keywords}

Data use. Organizational context. Principal leadership. School climate. Confidence in data. 


\section{Sumário}

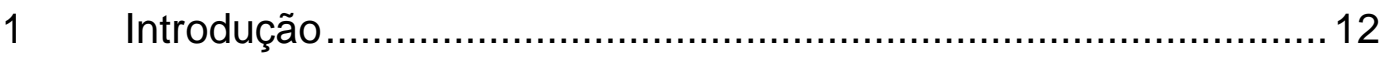

2 A produção de conhecimento sobre uso de dados e gestão escolar. 18

2.1 O que dizem as pesquisas sobre gestão escolar e uso de dados .18

3 O contexto organizacional para uso pedagógico dos dados educacionais em Minas Gerais ......................................................25

3.1 A Secretaria Estadual de Educação de Minas Gerais e os processos organizacionais para uso de dados ............................................... 33

3.2 A escolha das escolas e a pesquisa de campo .......................... 47

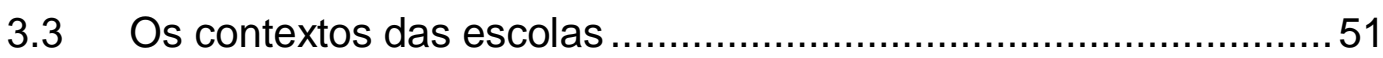

3.4 As escolas e os processos organizacionais para uso de dados ....68

3.4.1 O Dia do Currículo: orientações institucionais ................................69

3.4.2 A execução do Dia do Currículo ................................................ 71

3.4.3 A formação para o uso dos dados .............................................. 76

4 Racionalidade burocrática e Gestão Escolar .................................34

4.1 Racionalidade, burocracia e o gestor escolar .............................. 80

4.2 O lugar do gestor escolar na burocracia ...................................... 86

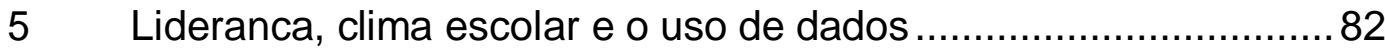

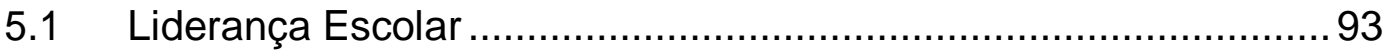

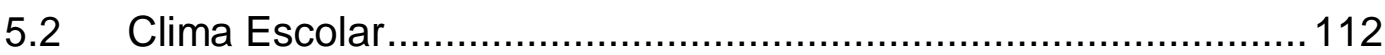

6 Confiança nos dados e o uso de dados ......................................97

6.1 Modernidade e Confiança......................................................120

6.2 Confiança e uso dos dados ...................................................126

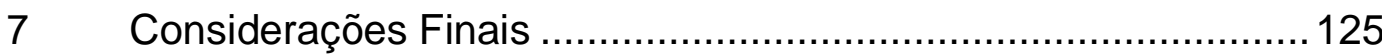

8 Referências bibliográficas ....................................................136

Apêncice A - Roteiro de entrevista para equipe gestora ..............143 
SumáP̂Pêndice B - Fotos da escola Travessia.................................... 144

Apêndice C - Fotos da escola Jardim Botânico ..........................147 


\section{Lista de abreviaturas e siglas}

ANPAE Associação Nacional de Política e Administração da Educação

ANPEd Associação Nacional de Pós-Graduação e Pesquisa em Educação

ATBs Assistentes Técnicos de Educação Básica

ASBs Auxiliares de Serviços da Educação Básica

BNCC Base Nacional Curricular Comum

DED Diário Escolar Digital

DAFI Diretoria Administrativa e Financeira

DIRE Diretoria Educacional

DIPE Diretoria de Pessoal

DIVAE Divisão de Atendimento Escolar

DIVEP Divisão Pedagógica

GESQ Grupo de Pesquisa em Gestão e Qualidade da Educação

ICG Índice de Complexidade de Gestão

Inse Indicador de Nível Socioeconômico

NTE Núcleo Tecnológico Educacional

PAAE Programa de Avaliação da Aprendizagem Escolar

PROALFA Programa de Avaliação da Alfabetização

PROEB Programa de Avaliação da Educação Básica

PPP Projetos Políticos Pedagógicos

Simave Sistema de Avaliação da Educação Pública

Simade Sistema Mineiro de Administração Escolar

SEE Secretaria Estadual de Educação

Sedine Serviço de Documentação e Informação Educacional

SRE Superintendência Regional de Ensino

ZEIS Zonas de Especial Interesse Social 


\section{Lista de Figuras}

Figura 1 - Modelo conceitual sobre o uso de dados na escola................27

Figura 2 - Ciclo de Uso de dados .............................................. 28

Figura 3 - Dimensões relacionadas ao contexto organizacional da escola para o uso de dados.

Figura 4 - Fatores que influenciam no processo do uso pedagógico dos dados educacionais na escola

Figura 5 - Fatores que influenciam no processo de uso pedagógico dos dados educacionais na escola ............................................................ 25

Figura 6 - Superintendências Regionais de Ensino de Minas Gerais ...... 34

Figura 7 - Organograma de uma SRE porte II .................................... 35

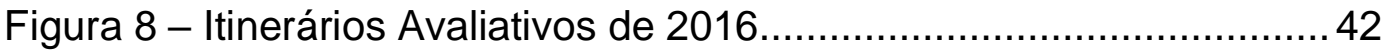

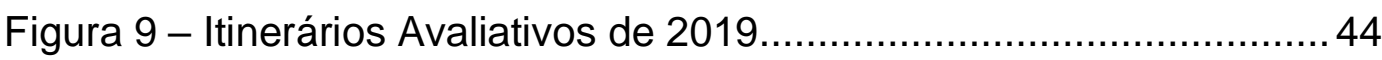

Figura 10 - Circuito de Gestão do Programa Jovem de Futuro .............. 46

Figura 11 - Mapa com as Regiões de Juiz de Fora .............................52

Figura 12 - Distorção idade-série escola Travessia/9ªno - 2007-2018 .65

Figura 13 - Distorção idade-série escola Jardim Botânico/9ano - 20072018 66

Figura 14 - Fatores que influenciam no processo de uso pedagógico dos dados educacionais.

Figura 16 - Fatores que influenciam no processo do uso pedagógico dos dados educacionais na escola 82

Figura 17 - Modelo de quatro caminhos ........................................99

Figura 18 - Modelo de análise do uso de dados educacionais ...............97 


\section{Lista de Gráficos}

Gráfico 1 - Série histórica do Ideb/9a ano - Brasil, Minas Gerais, Escolas Travessia e Jardim Botânico

Gráfico 2 - Indicador de Rendimento (taxa de aprovação)/9ªno das escolas 64

Gráfico 3 - Média de proficiência das escolas na Prova Brasil em Língua Portuguesa/9ano.

Gráfico 4 - Média de proficiência das escolas na Prova Brasil em Matemática/9ano

Gráfico 5 - Média desempenho PROEB/SIMAVE - 9ano - Língua

Portuguesa 67

Gráfico 6 - Média desempenho PROEB - 9a ano - Matemática 67 


\section{Lista de Tabelas}

Tabela 1 - Dados compilados das 14 escolas ........................................ 49

Tabela 2 - Domínios e práticas da liderança transformacional ..................94

Tabela 3 - Recursos e habilidades de liderança ....................................98 
A tarefa não é tanto ver aquilo que ninguém viu, mas pensar o que ninguém ainda pensou sobre aquilo que todo mundo vê.

Arthur Schopenhauer. 


\section{Introdução}

$\mathrm{Na}$ presente pesquisa iremos olhar para a escola pelo viés da sociologia das organizações o que significa assumi-la enquanto objeto de análise e uma instância de reprodução e de produção de práticas. De acordo com Lima (2003) a reprodução opera no plano organizacional da escola e estaria relacionada às orientações normativas (legislações) a que elas estão submetidas. Por outro lado, a escola é o lugar onde cotidianamente práticas sociais são produzidas nas interações entre os sujeitos e que, por isso, são múltiplas e próprias de cada contexto.

A instituição escolar que ora estamos analisando situa-se no contexto da modernidade ${ }^{1}$ (Giddens, 1991) e está submetida a mecanismos burocráticos cuja responsabilidade gerencial, que engloba aspectos administrativos, de pessoal, pedagógicos e financeiros, recaem sobre o diretor escolar. Sendo assim, nosso foco analítico dentro da instituição escolar está nas ações do diretor como burocrata do estado.

Pensar a atuação burocrática do diretor escolar significa pensar na constituição do campo da administração escolar no Brasil. De acordo com Souza (2006), Antônio Carneiro Leão, em 1939, foi um dos primeiros pesquisadores a discutir a administração escolar no Brasil e, segundo a teoria deste, o diretor escolar era um defensor da política educacional e um representante oficial do Estado com um forte legado administrativo. Mais tarde, em 1952, José Querino Ribeiro constrói as bases para uma teoria da administração escolar pautada nos princípios e métodos da administração científica. Critica, dessa forma, o modelo tradicional de organização escolar na medida em que o referido autor apresenta um ensaio teórico no qual sugere formas de organização e administração da escola. Ribeiro reconhece que os princípios e métodos da administração cientifica são aplicáveis na escola, uma vez que ela apresenta aspectos comuns a outras

\footnotetext{
${ }^{1}$ De acordo com Dias (2005, p.87) "Giddens não segue a orientação de alguns autores que nomeiam a sociedade contemporânea como pós-moderna ou pós-industrial. Em vez disso, prefere a terminologia modernidade alta ou tardia, para indicar que os princípios dinâmicos da modernidade ainda se encontram presentes na realidade atual.".
} 
organizações (Sousa, 2006). Atrelado a isso, o autor destaca que a escola, assim como o Estado, sofreu alterações em sua função social e, na mesma medida em que a oferta estatal dos serviços educacionais se tornou crescente, cresceu também a demanda de uma escola para todos, em toda parte e de todos os tipos (Sousa, 2006). Contudo, Sousa (2206) afirma que o problema desta teoria é a falta de empiria sobre a prática da gestão escolar, nas palavras do autor, "o problema está na proposição de um modelo de organização e gestão das escolas, ao que parece, pouco (ou nada!) embasado na prática real da gestão escolar." (Sousa, 2006, p.38). Já em 1976 Lourenço Filho agrega um novo elemento à teoria da administração escolar brasileira, qual seja: o papel das pessoas na organização escolar. Segundo este autor era necessário considerar os impactos que as relações interpessoais tinham na organização escolar (Sousa, 2006). Essas teorias iniciais sobre a administração escolar contribuíram para a construção do campo da gestão escolar no Brasil cujas bases teóricas se sustentavam na teoria da administração científica com uma grande valorização da face técnica dos processos e instrumentos da gestão escolar e que compreendiam os diretores escolares como chefes da instituição escolar e figuras centrais da sua gestão.

De acordo com Sousa (2006) Anísio Teixeira, nos anos 60, inaugura um novo tipo de pensamento sobre a administração escolar, pois para ele a razão do trabalho do administrador escolar era, antes de tudo, pedagógica. Nesse sentido, a administração da escola precisava dar conta de profissionais cujas tarefas se complexificaram em função de uma organização escolar que se transformou em relação ao tamanho, a amplitude e a heterogeneidade. Sendo assim, a administração escolar era "uma ferramenta a serviço do desenvolvimento pedagógico da escola e não possui uma razão própria alheia ao trabalho docente e à função educativa da instituição." (Sousa, 2006, p. 48). Na virada dos anos 70 para os anos 80 , Sousa (2006) apresenta o pensamento de Bruno Sanders como um dos últimos autores da teoria clássica da administração escolar. Diferentemente de seus antecessores, Sanders compreende o campo da educação como um terreno híbrido que conta com a contribuição de diferentes áreas e afirma que a administração escolar é um ato pedagógico e político. 
Essas duas últimas teorias sobre a administração escolar refletem o contexto político social do Brasil que vivia um período de ditadura militar (1964-1985) e, por isso, reforçam o caráter político e pedagógico da, agora chamada, gestão escolar em substituição à nomenclatura administração escolar (Sousa, 2006).

Após o período da ditadura militar, o Brasil passou por um processo de abertura política no qual segmentos da sociedade civil lutavam por direitos sociais no contexto de redemocratização da sociedade brasileira. Concomitante a isso, a partir da década de 1990, um novo modelo de gestão pública é introduzido no Brasil como resultado das ideias neoliberais que circulavam no mundo. A Nova Gestão Pública propunha a descentralização do Estado sob a justificativa de atender às necessidades dos cidadãos. A reforma gerencial criou novas instituições legais e organizacionais para profissionalizar e modernizar a burocracia estatal e, para gerenciar tais instituições era essencial dar autonomia aos administradores públicos, valorizando sua capacidade de tomar decisões (Bresser-Pereira, 2000).

No campo da educação, as reinvindicações eram, sobretudo, por uma escola pública e de qualidade e, para tanto, se tornou necessária uma remodelação nas formas de organização dos sistemas escolares e das escolas de forma a atender tais necessidades. Uma das mudanças realizadas foi a atribuição de maior autonomia aos sistemas e às escolas (Machado \& Falsarella, 2020). Tal reforma gerencial reverberou no âmbito da gestão escolar na medida em que as novas teorias, sobretudo aquelas apresentadas por Miguel Arroyo e Vitor Paro, definiram a gestão da escola como um ato político (Sousa, 2006).

Um dos impactos da Nova Gestão Pública na educação foi a autonomia gerencial concedida às unidades escolares que abriu espaço para o empoderamento da gestão escolar sob a justificativa de que a descentralização das decisões gerenciais e financeiras das escolas representava uma aproximação da escola com seus usuários. A lógica embutida neste pensamento era que a unidade escolar tinha mais consciência de seus problemas do que a burocracia regional e, com isso, buscava-se fortalecer a cultura da escola; viabilizar a liderança do gestor, 
favorecer processos de decisão mais colaborativos; aproximar a escola dos pais e liberar a escola dos controles excessivamente burocráticos (Prado, 2012) e, assim, construir as bases para a efetivação da gestão democrática. Ademais, esta perspectiva gerencial requisitava uma transformação das competências do gestor escolar que precisaria desenvolver habilidades empreendedoras, de liderança e de responsividade às demandas da educacionais advindas da comunidade escolar e das políticas públicas.

No entanto, este processo de descentralização gerencial da educação, diferentemente do preconizado, sobrecarregou os gestores escolares com processos burocráticos e financeiros uma vez que eles passaram a ser os responsáveis legais por todos esses processos e, por não poderem se furtar de realizar essa função administrativa, acabaram por negligenciar o lado pedagógico.

A ênfase no alcance de resultados com base na estruturação de sistemas de avaliação da aprendizagem das escolas foi uma outra consequência da reforma gerencial. Contudo, para que esses sistemas fossem viáveis, o Estado tinha que definir um currículo padronizado que, posteriormente, pudesse ser avaliado em termos de qualidade do serviço ofertado e aprendizagem dos alunos. É nessa conjuntura do final dos anos 80 e década de 1990 que surgem os sistemas de avaliações externas padronizados. Como nosso foco de pesquisa recai sobre a rede estadual de educação de Minas Gerais daremos especial atenção aos acontecimentos da reforma gerencial neste estado.

A reforma gerencial em Minas Gerais, conhecida como Choque de Gestão, aconteceu entre os anos de 2004 a 2010 e tinha como objetivo implementar uma administração voltada para resultados. Para que isso fosse possível, no campo da educação, foi necessária uma padronização dos conteúdos curriculares, da aplicação das avaliações educacionais e a estruturação de um sistema de metas. O marco inicial desta reforma empreendida pelo governo mineiro foi relativo à institucionalização de um currículo básico comum em 2004 que reverberou em mudanças na matriz curricular do Sistema de Avaliação da Educação Pública (Simave). Esse sistema, que existia desde 1992, tinha como objetivo realizar diagnósticos 
sobre a aprendizagem dos estudantes em língua portuguesa e matemática e compor um acervo de dados e informações sobre as escolas que constituíssem base para o desenho de um plano de melhoria do ensino ofertado (Antunes, 2015).

Com a consolidação de um sistema de avaliação que produzia um diagnóstico da qualidade da educação ofertada na rede estadual de educação de Minas Gerais, iniciou-se o investimento na construção de um sistema padronizado de gestão de processos administrativos e educacionais. O Sistema Mineiro de Administração Escolar (Simade) surge em 2008 e tem como objetivo auxiliar a organização dos dados educacionais - cadastro, matrícula, enturmação, lançamento de notas e frequência, resultado final (aprovação, reprovação, dependência, evasão, abandono) -, além de possibilitar o monitoramento do desempenho, aprendizagem e frequência discente. Trata-se de um software implementado em todas as escolas nas quais diretores e secretários escolares são responsáveis por inserir e atualizar os dados cotidianamente, vez que esses são usados como insumos para decisões da escola, da Secretaria Estadual de Educação de Minas Gerais (SEE/MG) e migrados anualmente para o Censo Escolar.

Lima (2019) buscou compreender, através de uma pesquisa quantitativa, os usos dos dados do Simade pelos gestores escolares e um dos resultados encontrados foi que os diretores têm um nível de conhecimento inferior ao dos secretários e Assistentes Técnicos de Educação Básica (ATBs) para utilizar o SIMADE. Como justificativa para isso, Lima (2019) aponta que, contrariamente ao prescrito na Resolução 1.180 de 28 de agosto de 2008 que atribui ao diretor essa demanda, a responsabilidade em relação ao sistema nas escolas é dos secretários e ATBs. Diante disso, a autora conclui que é de total responsabilidade da secretaria a alimentação do sistema e a direção assume uma postura de supervisão do processo. Outro resultado desta pesquisa diz respeito à autoeficácia do diretor para uso do Simade que, quanto maior, mais este sujeito valorizava as tarefas pedagógicas como as atividades voltadas para a promoção da aprendizagem, a preocupação com o rendimento e o desempenho discentes. 
Neste estudo, diferentemente da pesquisa de Lima (2019), mas de maneira complementar, propomos uma pesquisa qualitativa, por meio de estudos de caso, na tentativa de compreender como se dão, no cotidiano da gestão escolar, os processos e ações de uso dos sistemas de gestão e avaliação mineiros. Sendo assim, buscaremos compreender nas entrelinhas do uso dos sistemas, de que forma os diferentes fatores organizacionais e atores educacionais influenciam o uso pedagógico dos dados na gestão das escolas.

O cenário até aqui desenhado retratou o contexto de desenvolvimento do campo da administração/gestão escolar e da reforma gerencial e suas consequências para a rede pública educacional de Minas Gerais. Agora as escolas não só detinham gerência sobre os processos administrativos e burocráticos como também tinham à sua disposição uma gama de dados educacionais. Uma premissa que também é correlata a esse foco na gestão das escolas são as pesquisas sobre eficácia escolar que realçam o papel dos gestores enquanto lideranças para promover um melhor desempenho dos alunos e os dados disponibilizados são ferramentas para que estas lideranças/diretores gerenciem sua unidade educativa de forma eficaz.

Todavia, conforme levantamento bibliográfico realizado para este estudo, o uso de dados pelos gestores escolares ainda é um desafio presente em diversos contextos educacionais brasileiros e internacionais e, por conta disso, é foco de interesse desta pesquisa. Portanto, elencamos como questão de pesquisa: Como articular os diferentes fatores organizacionais e atores educacionais para compreender o uso pedagógico dos dados na gestão das escolas?

Para responder a essa questão elencamos os seguintes objetivos específicos:

i. Compreender quais fatores organizacionais da rede de ensino e da escola influenciam o uso pedagógico dos dados;

ii. Analisar a influência da liderança do diretor e do clima escolar no processo do uso pedagógico dos dados;

iii. Entender em que medida a percepção da confiabilidade/fidedignidade dos dados disponíveis reflete no uso 
pedagógico dos dados pela gestão da escola e qual a racionalidade que subjaz o uso dos dados educacionais.

O texto que ora apresentamos possui, além desta introdução, 6 capítulos. No capítulo inicial apresentamos a revisão de literatura sobre gestão escolar e o uso pedagógico de dados e, como produto deste processo, mapeamos sete fatores que influenciam no processo do uso pedagógico dos dados na escola. A partir disso, resolvemos refletir teoricamente sobre cada um dos fatores e, por conta disso, em cada um dos capítulos seguintes discutimos um conjunto de fatores ou um fator separadamente.

No terceiro capítulo nos dedicamos a analisar quatro fatores: o contexto organizacional, os sistemas de gestão e o suporte e acesso à tecnologia, bem como a formação ofertada pela rede para fazer uso dos dados. Para tanto, descrevemos e analisamos os contextos organizacionais da SEE/MG, da SRE de Juiz de Fora e das escolas que fizeram parte desta pesquisa.

No quarto capítulo trouxemos para a arena de discussão, o quinto fator, qual seja, a racionalidade do diretor como interveniente no processo de uso dos dados e, para tanto, pautamos nossas análises no referencial de Weber (Vandenbergh, 2012). A partir do desenho da lógica operacional do burocrata na modernidade conceituamos o gestor escolar enquanto burocrata híbrido que ora se comporta como um burocrata de nível de rua, ora como burocrata de médio escalão. No quinto capítulo tratamos sobre os dois últimos fatores mapeados que influenciam no processo de uso de dados na escola, a saber: a liderança do diretor e o clima escolar.

O capítulo final da tese, à guisa de considerações finais, apresenta uma nova hipótese explicativa para a compreensão dos processos do uso pedagógico dos dados na gestão da escola: a confiança nos dados. A construção teórica deste fator se dá a partir do referencial de Giddens (1991) e dos mecanismos de funcionamento da modernidade. 


\section{2 \\ A produção de conhecimento sobre uso de dados e gestão escolar}

Neste capítulo apresentaremos a revisão de literatura empreendida na presente pesquisa com o intuito de conhecer os estudos nacionais e internacionais publicados acerca da temática sobre gestão escolar e uso de dados no período de 2010 a 2019. Para tanto, elegemos como periódicos a serem pesquisados aqueles cujo Qualis Capes na área de Educação no quadriênio 2013-2016 foi A1 e A2. Também foram escolhidos os anais da Associação Nacional de Pós-Graduação e Pesquisa em Educação (ANPEd) e Associação Nacional de Política e Administração da Educação (ANPAE) por sua relevância no campo de pesquisa na área de Educação. O levantamento realizado nos eventos da ANPEd e da ANPAE foi feito a partir da consulta online aos Anais publicados no período de 2010 a 2019. Nos Anais da ANPEd a busca se deu nos grupos de trabalho de Sociologia da Educação (GT14) e de Estado e Política Educacional (GT05), uma vez que compreendemos serem esses os GTs cuja discussão poderia atrair trabalhos afins a nossa temática de pesquisa. Já nos anais da ANPAE a busca foi realizada dentro das categorias de apresentação: comunicação oral, relatos e pôsteres.

Por fim, mapeamos as publicações da revista Educational Administration Quaterly, que embora não faça parte do Qualis Capes, publica estudos que dialogam com o tema desta tese. Nos locais mencionados buscamos pelos trabalhos cujos títulos tinham as palavraschaves: uso de dados, gestão escolar, indicadores educacionais, avaliação externa. Nos periódicos em outros idiomas traduzimos as palavras-chave nas respectivas línguas estrangeiras.

\section{1}

\section{O que dizem as pesquisas sobre gestão escolar e uso de dados}

A relação entre o papel da gestão escolar e o uso dos dados tem sido foco de pesquisas recentes no campo da educação em âmbito nacional e internacional, mas apesar do interesse crescente, sobretudo a 
partir da crescente disseminação de sistemas de avaliação e disponibilização pública dos dados por eles produzidos, a quantidade de publicações ainda é pequena conforme veremos a seguir. Todos os artigos e trabalhos apresentados nos anais da ANPAE e ANPEd foram lidos na íntegra. Apesar dos estudos terem sido selecionados por abordarem de alguma forma a relação entre a gestão escolar e o uso de dados, as temáticas das pesquisas variavam. Para apresentar os achados referentes às pesquisas publicadas, elas foram categorizadas em dois grupos, tendo em vista o seu objetivo central: i) Políticas educacionais de avaliação, responsabilização e gestão escolar; ii) Uso de dados e gestão escolar. No primeiro grupo os trabalhos eram, majoritariamente, nacionais e as discussões estavam atreladas ao uso de dados das avaliações externas e de políticas derivadas dessas avaliações no cotidiano escolar, ou seja, neste caso, as pesquisas buscavam compreender como aconteciam as apropriações dos dados das avaliações externas pela escola. No segundo grupo todas as pesquisas eram de autoria internacional e tratavam sobre o uso de dados de diversas fontes pela gestão escolar. No que diz respeito à metodologia, tanto no âmbito internacional quanto no nacional as pesquisas foram, em sua maioria, de cunho qualitativo baseadas em pesquisa documental e estudos de caso com realização de entrevistas, grupos focais e aplicação de questionários.

Boa parte das discussões nacionais apontavam que as práticas de uso dos dados das avaliações externas tendem a se limitar à consulta ao sistema de informação onde os dados estão disponíveis sem, de fato, gerar ações de cunho pedagógico no ambiente escolar. Sobre isso Sousa e Oliveira (2010, p. 818) apontam que o sistema de avaliação tende a se "limitar a um sistema de informação educacional. Sem dúvida, a produção de informação é uma etapa do processo avaliativo, mas esse só se realiza quando, a partir de informações, ocorrerem julgamento, decisão e ação”. A leitura dos trabalhos indicou alguns motivos que justificariam certa limitação para o uso dos sistemas e dos dados neles disponíveis como apresentaremos a seguir.

Silva (2013) e Freitas e Ovando (2015) argumentam que há uma grande dificuldade, por parte da equipe gestora e dos professores, em 
compreender a relação entre avaliação externa e currículo, o que acaba tornando a prática de uso de dados restrita à construção de simulados na expectativa de que isso gere uma melhora nos resultados de desempenho. Para além disso, Silva (2013) aponta que a estrutura organizacional das secretarias de educação, o tipo de acompanhamento do trabalho escolar, a relação existente entre avaliação externa e currículo e a formação para compreensão e uso dos dados são alguns fatores que podem favorecer ou dificultar o uso dos dados pelas escolas.

Outro argumento apresentado por Fontanive (2013) diz respeito à falta de conhecimento, por parte de professores, coordenadores pedagógicos e diretores, sobre as tecnologias empregadas na avaliação dos estudantes e nos mecanismos e materiais utilizados na divulgação dos resultados, o que dificulta a prática de uso de dados com fins pedagógicos na escola. Sobre isso, algumas pesquisas (Sousa \& Oliveira, 2010; Vidal \& Lerche, 2011; Wayman et al., 2012; Machado \& Alavarse, 2014; Farrell, 2015; Roegman et al., 2017; Silva, 2017; Cerdeira et al., 2017; Park, 2018; Roegman et al. 2019) enfatizam a importância de contextualizar os dados da escola e a necessidade de estímulo e apoio das instâncias superiores para o processo de uso dos dados na escola. Ou seja, políticas públicas que fomentem o uso de dados nas escolas são tão importantes quanto a promoção de formação continuada para gestores e docentes das escolas (Ribeiro \& Gusmão, 2010; Paes de Carvalho et al., 2011; Fontanive, 2013; Rosistolato \& Viana, 2014).

A leitura dos artigos também possibilitou evidenciar que a liderança do diretor é primordial para que o uso dos dados se torne parte da cultura da gestão pedagógica da escola. Parte considerável das práticas de uso dos dados relatadas nas pesquisas mostram que o conhecimento e a habilidade do diretor em usar os dados é fundamental para que o corpo docente também se torne participante deste processo. Por conta disso, a tomada de decisão com base em dados depende fortemente de uma liderança que apresente os dados e os coloque como pauta para serem discutidos com os profissionais da escola.

Notoriamente isso está posto nos artigos internacionais haja vista que o diretor escolar é, pelo cargo que ele ocupa, considerado e denominado 
líder. Ou seja, a maior parte das pesquisas internacionais, sobretudo na literatura anglo-saxônica, se referem ao gestor escolar como sinônimo de liderança (Wayman et al., 2012; Supovitz et al., 2012; Park \& Guerra, 2013; Farrell, 2015; Roegman et al., 2017; Leithwood et al., 2019). Nas pesquisas nacionais, o gestor escolar também aparece como ator chave neste processo na medida em que ele é o responsável legal por diversas instâncias na escola e é o elo entre a secretaria de educação e a escola. Por conta disso, normalmente, ele é o sujeito foco das políticas públicas para uso de dados (Sousa \& Oliveira, 2010; Ribeiro \& Gusmão, 2010; Paes de Carvalho et al., 2011; Martins \& Sousa, 2012; Rosistolato \& Viana, 2014; Freitas \& Ovando, 2015; Cerdeira et al., 2017).

Majoritariamente as pesquisas internacionais argumentam que, desde a política do No Child Left Behind, os EUA vêm investindo em políticas e programas que fomentem o uso de dados no contexto educacional e, em especial nas escolas, para que as decisões dos gestores sejam tomadas com base nas evidências que os dados fornecem. Como resultado houve uma crescente demanda sobre os educadores para acessar, compreender e utilizar dados sobre os estudantes e a escola. Contudo, Farrell (2015) ressalta que, de muitas maneiras, a prática do uso de dados está à frente da pesquisa. Políticas e intervenções para promover o uso de dados ultrapassam, em muito, a pesquisa sobre o processo, o contexto e as consequências desses esforços. Para a autora, por isso são necessárias mais pesquisas para entender não somente quais fatores contextuais moldam os esforços para o uso de dados, mas como esses fatores permitem ou restringem o uso de dados para a melhora da aprendizagem.

Uma observação importante apontada por Farrell (2015) é a suposição, na literatura existente, de que os sistemas escolares são organizados de forma a promover o uso pedagógico dos dados com estruturas suficientes para apoiar a interpretação e a resposta dos educadores aos dados. De acordo com Farrell (2015) pesquisas anteriores sobre reformas educacionais sugerem que uma série de influências organizacionais regularmente moldam o trabalho nos sistemas escolares, incluindo a liderança do diretor, a estrutura da rede e a presença de parceiros externos. A autora argumenta que, apesar dos educadores terem 
acesso a uma variedade enorme de fontes de dados, eles podem não ter os conhecimentos e as habilidades para identificar questões, analisar resultados e tomar decisões. Ademais, afirma que os educadores escolares não só precisam de apoio, mas também de autoridade suficiente para tomar decisões com base em dados (data driven decision-making) ${ }^{2}$.

No tocante ao contexto organizacional, Farrell (2015) afirma que poucas pesquisas têm buscado compreender a relação deste com o uso de dados e ressalta que o contexto no qual as escolas estão inseridas influencia o tipo de uso que os dados terão: seja ele para fins de investigação e aprendizado profissional ou em direção ao cumprimento de metas de monitoramento e responsabilização. Para ilustrar este processo Farrell (2015) construiu o um modelo conceitual apresentado na Figura 1.

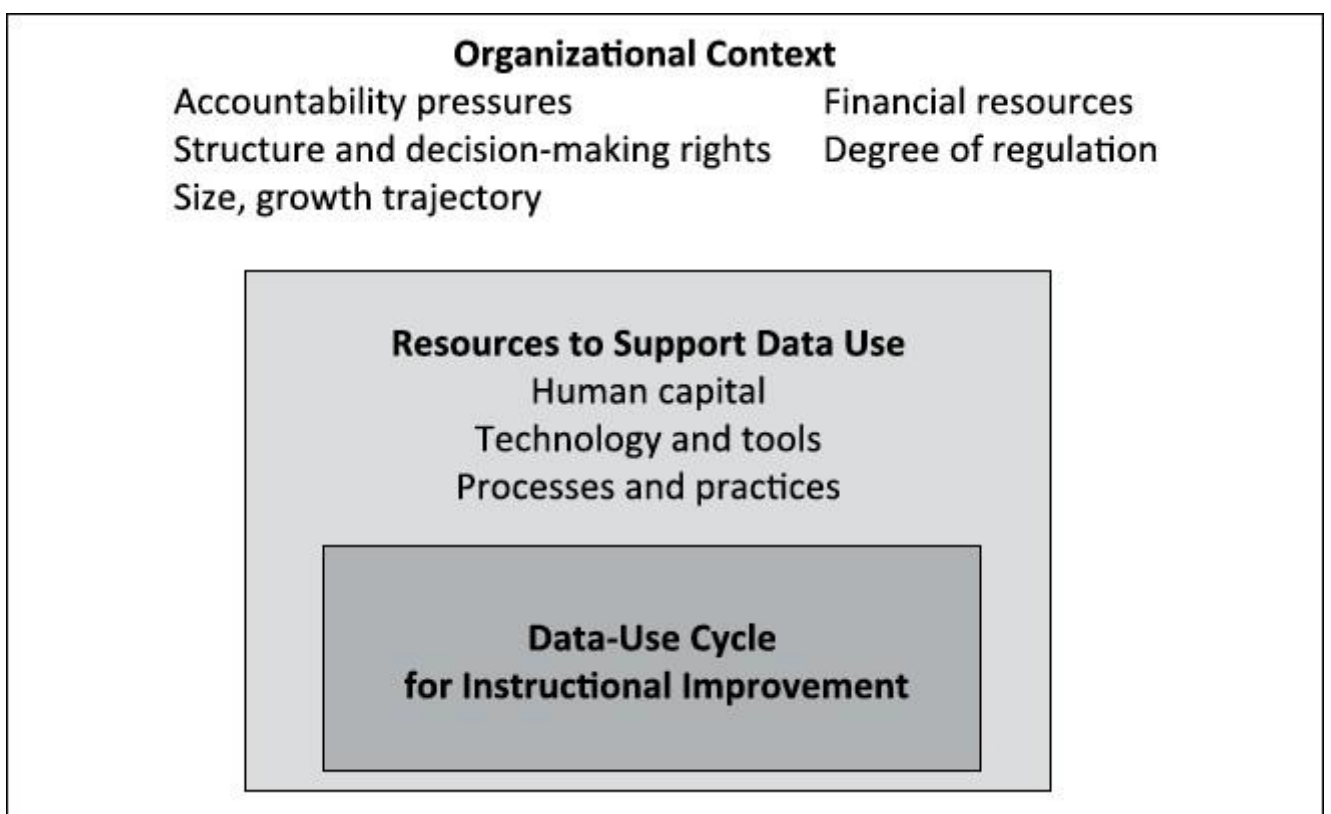

Figura 1 - Modelo conceitual sobre o uso de dados na escola Fonte: Farrell (2015, p. 443).

Esta representação nos ajuda a visualizar que, no contexto organizacional da escola, existem três dimensões que impactam o uso de dados: o próprio contexto da escola (clima, interações e relações interpessoais, percepções e expectativas sobre os alunos), os recursos

\footnotetext{
2 "Data driven decision-making is the iterative "collection, examination, analysis, interpretation, and application of data to inform instructional, administrative, policy, and other decisions and practice" (MANDINACH; JACKSON, 2012, p. 22).
} 
disponíveis para uso de dados e o ciclo de uso de dados. Para esta última dimensão, Farrell (2015) utilizou o ciclo proposto por Marsh (2012) apresentado a seguir.

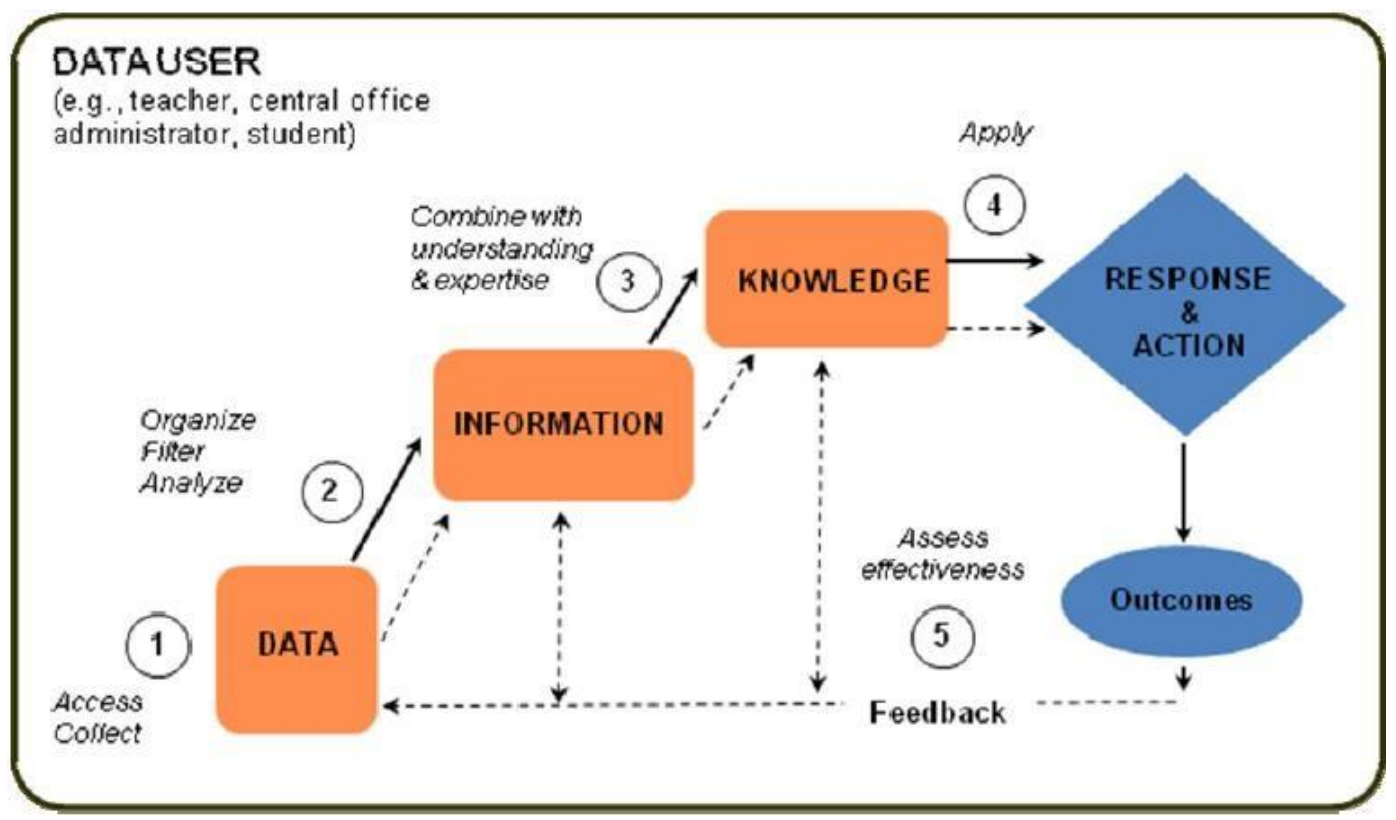

Figura 2 - Ciclo de Uso de dados

Fonte: Marsh (2012, s.p.).

Marsh (2012) explica que os dados podem ser de diferentes fontes (avaliação, sistemas gerenciais, anotações de professores, etc.) e que seria importante o cruzamento dos mesmos para pensar as práticas gestoras e pedagógicas das escolas e, a partir deste diagnóstico, reavaliar o que tem sido feito. A partir da compreensão e discussão dos dados com base na expertise dos envolvidos é produzido um conhecimento. Essas etapas estão representadas na Figura 3 como 1, 2 e 3 . Os momentos seguintes (passos 4 e 5) se referem às respostas e ações frutos das reflexões anteriores que, dependendo da situação, precisarão ser repensadas. No caso de um fluxo contínuo, a etapa seguinte seria avaliar a efetividade das ações e os resultados obtidos. As linhas pontilhadas indicam que em qualquer etapa podem ser necessários mais dados/informações antes de seguir para o próximo passo levando a ciclos de feedback ao longo do processo.

Wayman et al. (2012) argumentam que o uso dos dados é influenciado pelas atitudes dos sujeitos frente aos dados, pela liderança dos diretores e 
pelos sistemas de gestão onde os dados são disponibilizados (dimensões relacionadas ao contexto organizacional da escola). De maneira complementar, Vilardi e Paes de Carvalho (2019) ressaltam que este último aspecto possui uma via de mão dupla com o suporte e o acesso à tecnologia oferecido pela rede educacional para utilização de tais sistemas. Isso porque, na medida em que a maior parte dos sistemas de gestão são ferramentas online, é necessário que as escolas tenham uma boa conexão com a internet e que, ao mesmo tempo, tenham um suporte técnico que possa auxiliá-las no uso do sistema sempre que necessário. A seguir, na Figura 3, apresentamos o esquema que ilustra tais dimensões.

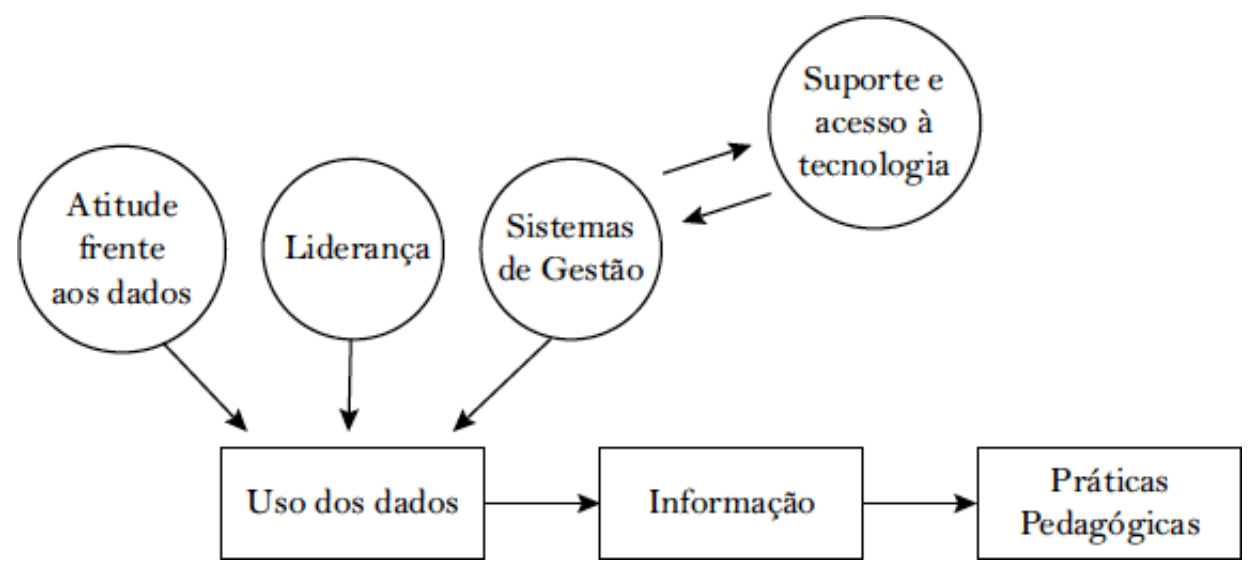

Figura 3 - Dimensões relacionadas ao contexto organizacional da escola para o uso de dados

Fonte: Vilardi; Paes de Carvalho (2019, p. 110) adaptado de Waymann et al. (2012).

Lasater et al. (2019) apontam que, no contexto americano, a expectativa para que as escolas fizessem uso dos dados fez com que muitos estados desenvolvessem seus próprios sistemas longitudinais. Contudo, esses sistemas estavam, muitas vezes, desconectados das reais necessidades dos profissionais das escolas, uma vez que os sistemas solicitam, principalmente, dados de prestação de contas de uso limitado para guiar o aprendizado. Ademais, muitos educadores não são adequadamente preparados para usar os sistemas (ou dados) eficientemente.

Como consequência, os autores argumentam que os formuladores de políticas parecem assumir que o uso de dados é um processo simples de unir dados e aplica-los para decisões escolares. Mas o uso de dados é 
complicado e necessita de um elaborado planejamento que envolve variáveis como o perfil do público da escola, fatores organizacionais e institucionais. Infelizmente os formuladores de políticas estão distantes destes contextos/variáveis o que faz com que as politicas, muitas vezes, sejam formuladas através de uma estrutura formal de rotinas e ferramentas para o uso de dados que não estão alinhadas com as necessidades dos gestores e demais atores escolares.

Concluímos então que o processo de uso de dados nas organizações escolares deve mobilizar diferentes fontes (capital humano, tecnologia e ferramentas, processos e práticas) para dar suporte aos educadores. Fatores pessoais e organizacionais podem moldar o gerenciamento do conhecimento nas organizações e, consequentemente, as dinâmicas de uso de dados e de alocação de recursos.

Outrossim, os dados não orientam automaticamente decisões. Antes os educadores precisam se envolver com os dados através de um processo cíclico de investigação, análise e interpretação para que eles possam fazer sentido no seu contexto e informar suas decisões e ações. Esse processo interpretativo é influenciado pela maneira como os usuários dos dados percebem e constroem sentidos sobre os dados, assim como também pela organizacão escolar e os contextos sociais e políticos nos quais essas interações acontecem. Especialmente sobre o modo como os gestores constroem sentidos sobre os dados, argumentaremos posteriormente que a racionalidade desses sujeitos, seja ela voltada para um valor ou para um fim, influencia o processo de uso de dados.

Apresentamos na Figura 4 os fatores que foram extraídos a partir do levantamento feito e que consideramos importantes para a compreensão da temática sobre o uso pedagógico dos dados educacionais e a gestão escolar. 


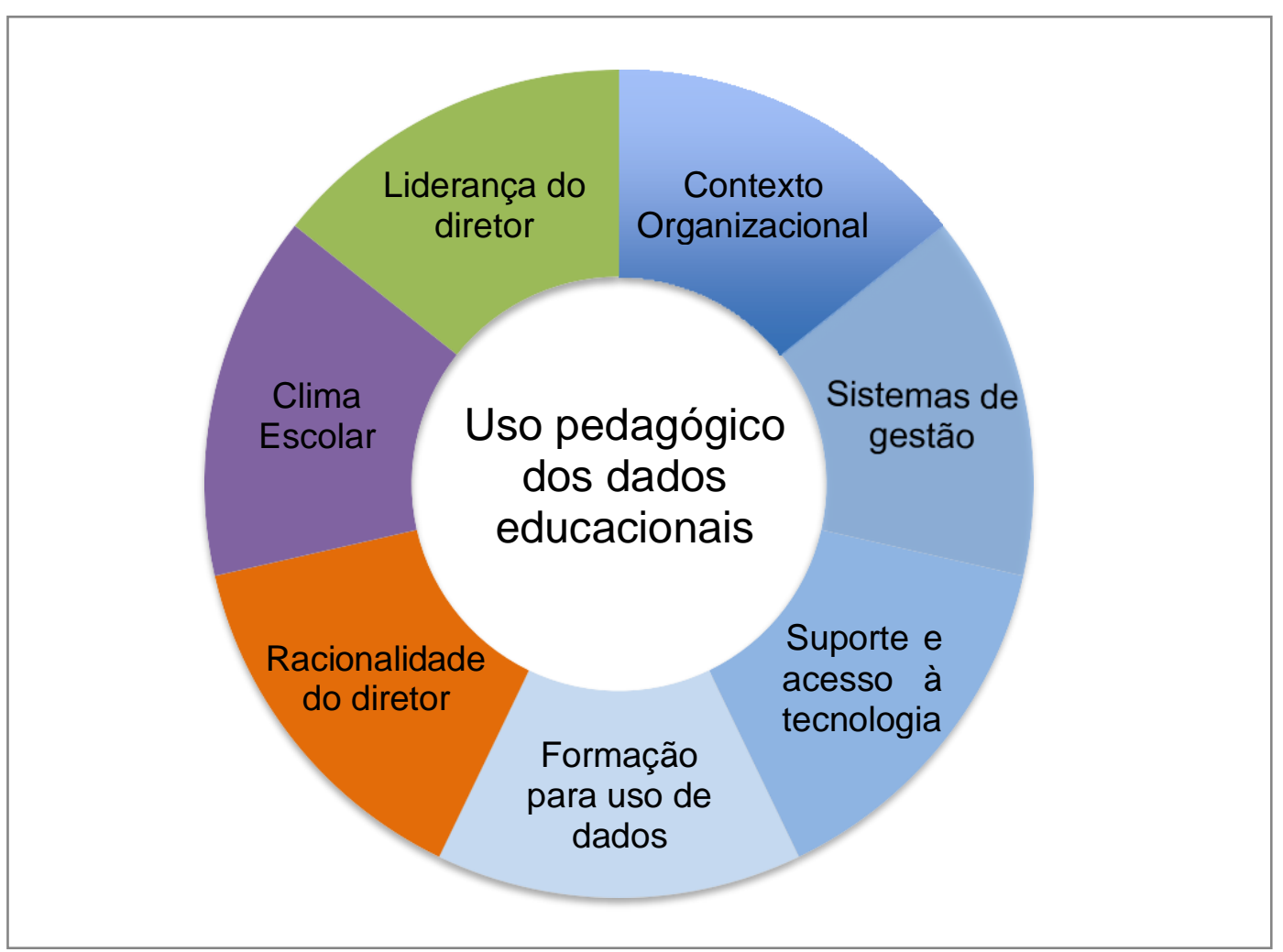

Figura 4 - Fatores que influenciam no processo do uso pedagógico dos dados educacionais na escola

Fonte: Elaborado pela autora (2020).

A identificação dos fatores que influenciam no processo de uso pedagógico dos dados educacionais na escola indicou que é necessário entender os diferentes fatores organizacionais e as ações dos atores escolares neste processo. Diante disso, no capítulo que segue, trataremos sobre quatro fatores, quais sejam: o contexto organizacional, os sistemas de gestão e o suporte e acesso à tecnologia, bem como a formação para fazer uso dos dados provenientes dos sistemas. 


\section{3 \\ O contexto organizacional para uso pedagógico dos dados educacionais em Minas Gerais}

Neste capítulo da tese pretendemos descortinar parte dos fatores que influenciam o uso pedagógico dos dados educacionais conforme Figura 5.

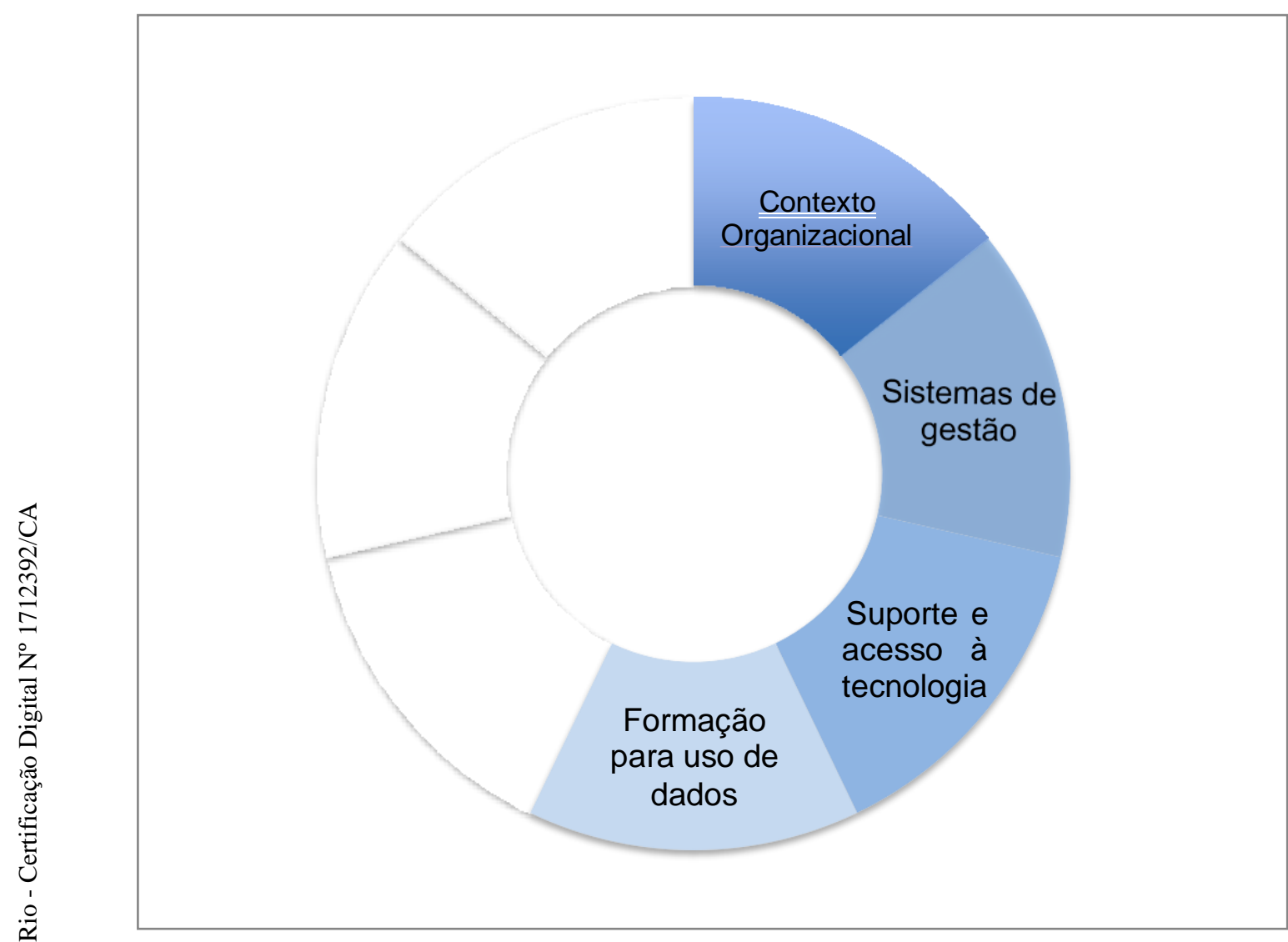

Figura 5 - Fatores que influenciam no processo de uso pedagógico dos dados educacionais na escola

Fonte: Elaborado pela autora (2020).

Para tanto, apresentaremos na primeira seção o contexto organizacional da SEE/MG e as políticas e os programas desenvolvidos cujo escopo é promover uma cultura de uso pedagógico de dados nas escolas. Isso é importante na medida em que as políticas educacionais pressionam cada vez mais as escolas para tomarem decisões baseadas em evidências, mas não necessariamente fornecem orientações sobre como os educadores devem olhar para os dados e pensar em que medida as evidências apresentadas podem servir de base para que decisões sejam 
tomadas. Além disso, como verificamos anteriormente, não há um único jeito de interpretar e utilizar as evidências já que alguns fatores condicionam este processo.

Muitas vezes as instâncias superiores da administração educacional assumem que seu papel é pautar e orientar a gestão da escola em consonância com suas expectativas de implementação ("top down") das políticas educacionais e, para que isso funcione, partem do princípio de que as ações dos agentes implementadores nas organizações são racionais e orientadas pela obediência às autoridades hierarquicamente superiores e independentes de seus valores, crenças, ou seja, não percebem as margens de discricionariedade que, de fato, existem nos processo de implementação de políticas orientadas e que as evidências são os instrumentos capazes de ajustar a normativa geral da política às especificidades contextuais de cada escola. Contudo, entre o que é postulado nas políticas públicas e o que de fato acontece nas escolas e entre o que as evidências mostram e o que os educadores compreendem e interpretam há espaços discricionários quase sempre ignorados ou subestimados pelas instâncias superiores.

Tendo isso em vista, a segunda seção deste capítulo apresenta o contexto organizacional das escolas que participaram desta pesquisa e 0 modo como as políticas públicas que supõem o uso pedagógico dos dados da SEE/MG foram implementadas.

\section{1}

\section{A Secretaria Estadual de Educação de Minas Gerais e os processos organizacionais para uso de dados}

Identificados na literatura os fatores que influenciam no processo de uso pedagógico dos dados educacionais na escola iremos, a seguir, apresentar a rede estadual de educação de Minas Gerais e as escolas foco deste estudo. Tal apresentação tem como intuito fornecer informações sobre quatro fatores que influenciam no uso de dados: o contexto político e organizacional no qual as escolas estão inseridas, os recursos (capital humano, tecnologias e ferramentas, processos e práticas) disponíveis e a formação oferecida pela rede estadual para uso dos dados. 
O estado de Minas Gerais possui 16.482 escolas, sendo que destas: 8.592 escolas são municipais; 3.616 escolas são estaduais; 4.224 escolas são privadas e 50 escolas são federais. Para gerir as escolas, a Secretaria Estadual de Educação de Minas Gerais (SEE/MG) possui uma estrutura descentralizada na qual as Superintendências Regionais de Ensino (SREs) situam-se como órgãos intermediários entre as escolas e a SEE/MG. Ao todo a SEE/MG possui 47 SRE's divididas em Porte I e Porte II dependendo do número de escolas sob sua jurisdição, conforme Figura 6.
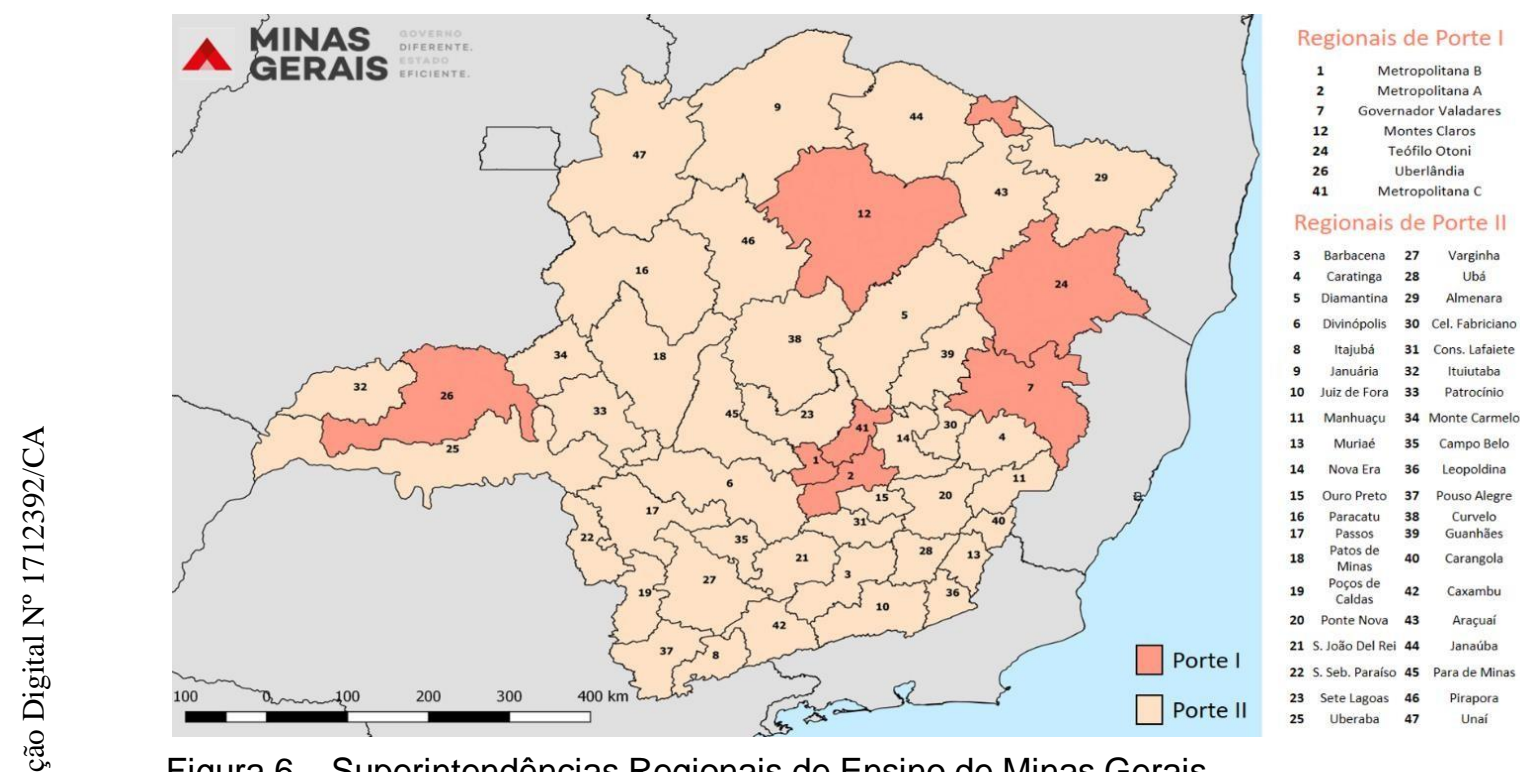

Figura 6 - Superintendências Regionais de Ensino de Minas Gerais Fonte: Minas Gerais (2019a).

As escolas estaduais que foram selecionadas para esta pesquisa pertencem a SRE de Juiz de Fora que possui sob sua jurisdição 30 municípios com 628 escolas, sendo: 302 escolas municipais; 227 escolas privadas; 96 escolas estaduais e 3 escolas federais. A SRE Juiz de Fora é considerada de Porte II porque comporta menos de 100 escolas estaduais e seu organograma é organizado de acordo com a Figura 7. 


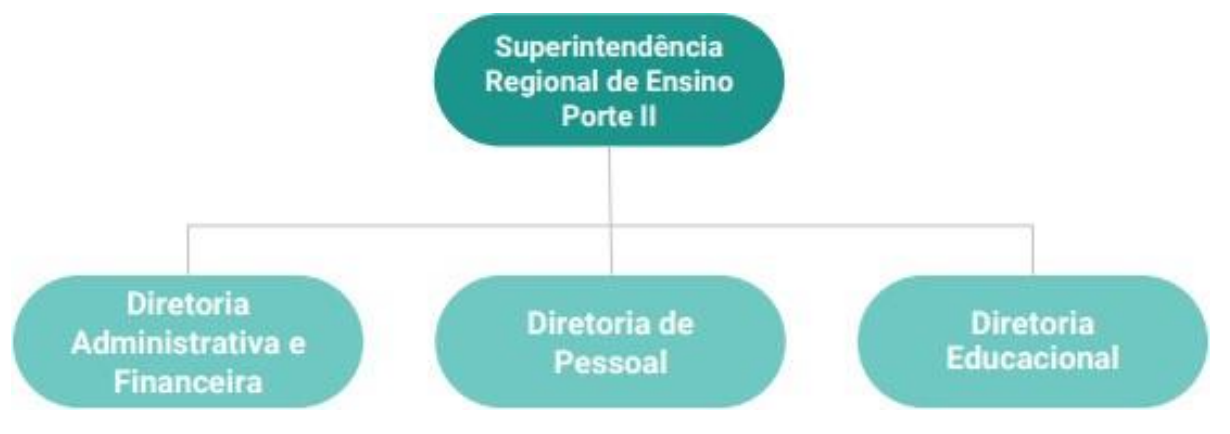

Figura 7 - Organograma de uma SRE porte II Fonte: Minas Gerais (2019b).

A SRE Juiz de Fora é gerenciada pelo Superintendente Regional de Ensino. O responsável pela regional coordena ações pedagógicas, administrativas e de gestão de recursos humanos nas escolas e na sede e tem entre seus objetivos melhorar os resultados educacionais, aprimorar a gestão escolar com foco na melhoria dos processos de ensinoaprendizagem e garantir o uso eficiente do recurso público da educação (Minas Gerais, [2019c]). Para tanto, conta com três diretorias: Diretoria Administrativa e Financeira (DAFI); Diretoria de Pessoal (DIPE) e Diretoria Educacional (DIRE).

A DAFI é responsável por programar, coordenar, avaliar e executar as atividades orçamentárias, financeiras e administrativas no âmbito da regional. Por sua vez, a DIPE planeja, coordena e avalia as ações de administração de pessoal e de gestão de recursos humanos e, por fim, a DIRE tem como papel atuar na orientação e implementação das políticas públicas pedagógicas da SEE/MG junto às escolas estaduais, coordenar reuniões pedagógicas e administrar e promover a articulação entre os setores Núcleo Tecnológico Educacional (NTE), Divisão de Atendimento Escolar (DIVAE) e Divisão Pedagógica (DIVEP).

Tendo em vista que o contexto organizacional no qual as escolas estão inseridas, o suporte tecnológico recebido e o acesso aos sistemas de gestão influenciam no modo como os diretores escolares fazem uso dos dados na sua prática de gestão escolar, iremos apresentar os setores da DIRE, pois são eles que oferecem este tipo de apoio pedagógico para as escolas e neles se concentram as demandas relativas à implementação e 
monitoramento de políticas, especialmente aquelas relativas ao Simave e o Simade.

O NTE fornece suporte técnico e administrativo da plataforma do website da SRE, do e-mail institucional e de conectividade nas escolas. A DIVAE tem como atividade precípua acompanhar e orientar as escolas estaduais sobre a inserção, atualização e a correção dos dados educacionais na plataforma do Simade; capacitar as equipes das escolas estaduais sobre os registros, as rotinas operacionais e funcionalidades do Simade; e orientar e acompanhar a realização das coletas do Censo Escolar junto às escolas estaduais.

O Sistema Mineiro de Administração Escolar (Simade) foi implementado na rede estadual em 2008 e, conforme apontamos, integrava a reforma gerencial do Choque de Gestão na tentativa de racionalizar os gastos. Tinha como objetivo auxiliar a organização dos dados educacionais - cadastro, matrícula, enturmação, lançamento de notas e frequência, resultado final (aprovação, reprovação, dependência, evasão, abandono) , além de possibilitar o monitoramento do desempenho, aprendizagem e frequência discente. Trata-se de um software implementado em todas as escolas nas quais diretores e secretários escolares são responsáveis por inserir e atualizar os dados cotidianamente, vez que esses são usados como insumos para decisões da escola, da Secretaria Estadual de Educação de Minas Gerais (SEE/MG) e migrados anualmente para o Censo Escolar (LIMA, 2019).

Por fim, a DIVEP concentra as ações de implementação, acompanhamento e monitoramento dos programas e projetos pedagógicos da SEE/MG nas escolas, em especial, o Simave.

O Simave, em sua configuração atual, é composto por três avaliações, a saber: o Programa de Avaliação da Educação Básica (PROEB) e Programa de Avaliação da Alfabetização (PROALFA), ambos aplicados anualmente e censitários, e o Programa de Avaliação da Aprendizagem Escolar (PAAE) que é diagnóstico e interno.

O PROEB, desde 2000, avalia os alunos dos 5ํ e 9a anos do Ensino Fundamental e $3^{\circ}$ ano do Ensino Médio nas disciplinas de Português e 
Matemática. Já o PROALFA avalia, desde 2005, o desempenho dos alunos do $3^{\circ}$ ano do Ensino Fundamental em Língua Portuguesa.

O PAAE é um sistema composto por duas avaliações: a avaliação anual da aprendizagem e a avaliação contínua da aprendizagem. No primeiro caso trata-se de uma avaliação realizada em três momentos do ano letivo com datas definidas pela SEE/MG cujo objetivo é ser uma ferramenta pedagógica para a prática dos professores do Ensino Médio das áreas de Ciências da Natureza, Ciências Humanas, Linguagens e Matemática, na medida em que fornece diagnósticos progressivos da aprendizagem e oferece subsídios para as intervenções pedagógicas visando a melhoria da aprendizagem. Já a avaliação contínua da aprendizagem trata-se de um sistema composto por um banco de itens que fica disponível para os professores e de onde eles podem gerar até duas provas por mês para acompanhar o desenvolvimento curricular.

Dentre os programas e projetos implementados, desde 2016 na rede estadual, daremos destaque para aos projetos Itinerários Avaliativos e Jovem de Futuro visto que essas políticas tinham como escopo promover a prática de uso pedagógicos de dados nas escolas. Por conta disso, as apresentaremos em seguida.

O projeto "Itinerários Avaliativos de Minas Gerais" teve duas edições, uma no ano de 2016 e outra no ano de 2019. Ambas tinham como proposta fomentar práticas de análise dos dados educacionais com o propósito de tornar a escola mais reflexiva e, assim, possibilitar a identificação dos principais fatores que interferem na qualidade do ensino ofertado e na aprendizagem dos estudantes. Para tanto, os Itinerários Avaliativos englobavam um conjunto de ações que deveriam ser desenvolvidas pelas escolas com o objetivo final de elaborar um Plano de Ação, cujo foco deveria ser melhorar o desempenho educacional dos estudantes, com base nas informações geradas pelas avaliações em larga escala e pelas avaliações internas da escola. Buscava, dessa forma, fomentar processos reflexivos dos gestores e da equipe das escolas sobre as suas práticas pedagógicas, permitir uma construção coletiva das avaliações internas e incentivar práticas de análise dos dados educacionais. 
A versão de 2016 estava organizada em 4 etapas, a saber: preparação; avaliação interna; plano de ação; e avaliação e monitoramento. Os sujeitos foco desta política eram o diretor escolar e a especialista de educação que deveriam implementar os itinerários nas suas escolas e envolver os demais atores escolares conforme fosse necessário. Faremos, a seguir, um parêntesis na descrição da política dos Itinerários Avaliativos para apresentar a estrutura das equipes de gestão das escolas públicas e os modos de acesso ao cargo para que fique clara as responsabilidades de cada pessoa dentro da rede e da política.

$\mathrm{Na}$ rede estadual de educação de Minas Gerais, para se candidatar ao cargo de diretor, é preciso realizar exame de Certificação Ocupacional de Diretor de Escola Estadual. A Certificação é pré-requisito para a participação dos candidatos no processo de escolha de diretor, que se dá por meio de consulta à comunidade escolar. O processo de Certificação Ocupacional não constitui concurso público para investidura no cargo, assim como não assegura ao candidato direito à ocupação no cargo ou nomeação. Esta limita-se em credenciar junto à SEE/MG profissionais para formar um banco de candidatos para o cargo em comissão de diretor de escola estadual, a validade da certificação é de quatro anos. Para participar do processo de Certificação Ocupacional o candidato deve possuir curso de licenciatura plena em Pedagogia ou licenciatura plena ou bacharelado/tecnólogo acrescido de formação pedagógica de docentes. A prova de certificação é composta por 60 questões objetivas de múltipla escolha cujos conteúdos dizem respeito à gestão pedagógica, gestão de pessoas e gestão administrativa e financeira. Uma vez certificados, eles estão aptos a se candidatarem junto à comunidade escolar. As nomeações dos servidores escolhidos para exercerem o cargo em comissão de diretor de escola são legitimadas por ato do Governador do Estado (Minas Gerais, 2020).

Como diretor o profissional é responsável pela gestão financeira, administrativa e pedagógica da escola. No que diz respeito à gestão financeira, nas escolas estaduais, cabe à Caixa Escolar o gerenciamento dos recursos financeiros. A Caixa Escolar é uma sociedade civil com personalidade jurídica e de direito privado cujo presidente é o diretor da 
escola. Cabe a ela administrar os recursos recebidos da SEE/MG, da comunidade, de entidades públicas e privadas e aqueles advindos da promoção de campanhas realizadas pela própria Escola (Minas Gerais, 2019).

Já a parte de gestão administrativa engloba desde aspectos normativos como elaboração do regimento escolar, arquivamentos e registros até a parte de gestão de pessoas, de matrículas dos alunos, do censo escolar e de organização de eventos sociais. Por fim, a gestão pedagógica envolve o acompanhamento do currículo escolar, os processos de ensino-aprendizagem, a elaboração e atualização do projeto político pedagógico da escola e tantas outras atividades que necessitem da autorização ou ciência da direção da escola (Minas Gerais, 2019).

Para gerir todos estes aspectos o gestor escolar se relaciona com diferentes atores escolares. No cotidiano da escola ele interage com os vice-diretores, secretários, os Assistentes Técnicos de Educação Básica (ATBs), especialistas, professores, alunos e pais/responsáveis. Com exceção dos professores, alunos e pais/responsáveis, todos os demais atores constituem a equipe gestora da escola.

O secretário escolar exerce cargo em comissão cuja indicação é feita pelo diretor da escola. Ele é responsável por gerir a secretaria da escola em seus aspectos administrativos e de pessoal. Para tanto, tem sob sua coordenação os ATBs cujo trabalho envolve o suporte administrativo na rotina escolar via recebimento e protocolo de documentos, atendimento ao público, organização dos arquivos, além de atividades de telefonia, digitação e manutenção de dados.

O especialista de educação básica assume o cargo via concurso público específico e, no ato da inscrição, ele seleciona o munícipio no qual deseja atuar. Os candidatos aprovados são classificados em ordem decrescente de nota final por município. O município de inscrição vincula o candidato automaticamente à SRE correspondente e a alocação nas escolas é feita, posteriormente, por cada SRE. No que diz respeito à formação, no último edital publicado, constava que o candidato deveria ter 


\begin{abstract}
1) diploma devidamente registrado de curso legalmente reconhecido de Licenciatura Plena em Pedagogia, com habilitação em Supervisão Pedagógica ou Orientação Educacional, expedido por instituição de ensino superior credenciada; ou

2) diploma devidamente registrado de curso legalmente reconhecido de Licenciatura Plena em Pedagogia, regulamentado pela Resolução CNE/CP oํ 01, de 15/05/2006, expedido por instituição de ensino superior credenciada;

ou

3) diploma devidamente registrado de curso legalmente reconhecido de Licenciatura Plena em qualquer área do conhecimento acrescido de certificado de pósgraduação em Supervisão Pedagógica ou Orientação Educacional, expedidos por instituição de ensino superior credenciada. (Minas Gerais, 2017, p.2).
\end{abstract}

O cargo de especialista de educação básica envolve a orientação, o acompanhamento, a implementação e a avaliação do processo de ensinoaprendizagem na escola. Sendo assim, é um trabalho que tem por objetivo criar condições para o bom desempenho de todos os envolvidos, especialmente do professor, para que mudanças ocorram na prática pedagógica. Dentre essas mudanças está a ação de possibilitar a consolidação de uma cultura de avaliação, de análise de dados e de intervenção pedagógica contínua para que os alunos melhorem seu desempenho escolar. Nessa perspectiva, o especialista deve assumir a postura de corresponsável pelos resultados de aprendizagem dos alunos, seja nas avaliações internas ou externas e, a partir deles, otimizar a execução dos projetos e políticas educacionais (Minas Gerais, 2018).

Além desses servidores, o diretor se relaciona com profissionais da instância superior da administração como os inspetores escolares e, quando necessário, o Superintendente Regional. No ano de 2019 a escolha para o cargo de Superintendente Regional foi feita via processo seletivo. Para participar deste processo os candidatos precisavam realizar o processo de Certificação Ocupacional e, estando aptos nesta etapa, passavam pelas etapas de análise curricular e entrevista.

O provimento do cargo de inspeção escolar é feito via concurso público específico e, de acordo com o último edital publicado, o candidato deveria ter

Diploma devidamente registrado de curso legalmente reconhecido de Licenciatura Plena em Pedagogia, com habilitação específica em Inspeção Escolar, ou de Licenciatura Plena em área específica, acrescida de pós-graduação em Inspeção Escolar, expedido por instituição de ensino superior credenciada (Minas Gerais, 2011 , s.p.). 
A Resolução CEE oo 457 de 30 de setembro de 2009 define a inspeção como "o processo pelo qual a administração do ensino assegura a comunicação entre os órgãos centrais, os regionais e as unidades de ensino, tendo em vista a melhoria da educação" (Minas Gerais, 2009, s.p.). Em função disso, "o Serviço de Inspeção Escolar está diretamente subordinado ao Gabinete da SRE, estruturando-se em nível central e em nível regional, sendo que sua ação ocorre em nível de unidade escolar" (Minas Gerais, 2017a, s.p.).

De acordo com a Resolução, SEE 3.428 de 13 de junho 2017 as atribuições do Inspetor Escolar são relacionadas a:

\footnotetext{
Orientação, assistência e controle do processo administrativo das escolas e, na forma do regulamento, do seu processo pedagógico. Orientação da organização dos processos de criação, autorização de funcionamento, reconhecimento e registro de escolas, no âmbito da sua área de atuação. Garantia de regularidade do funcionamento das escolas, em todos os aspectos. Responsabilidade pelo fluxo correto e regular de informação entre as escolas, os órgãos regionais e o órgão central da SEE:

a) Conferir a autenticidade e exatidão da documentação da escola, referendandose antes de seu encaminhamento à SEE,

b) Homologar as designações, assinando o QI, juntamente com o Diretor da Escola. Exercer outras atividades compatíveis com a natureza do cargo, previstas na regulamentação aplicável e de acordo com a política pública educacional. (Minas Gerais, 2017a, s.p.)
}

No que diz respeito à dinâmica de trabalho do serviço de inspeção da SRE de Juiz de Fora ela engloba a realização, em sistema de rodízio plantão, de atendimento ao público externo de terça-feira à sexta-feira de 08:00 às 17:00 horas; e a realização de reuniões semanais entre o grupo de inspetores e coordenação de inspeção para estudos de documentos oficiais encaminhados pela SEE para efetuar repasse e orientações às escolas, resolução de demandas administrativas e internas, além do planejamento das ações do grupo inspetores. Especificamente sobre a prática profissional dos inspetores escolares ela envolve: a realização de visitas às escolas a fim de efetuar o atendimento de demandas regulares, além de executar as demandas relacionadas à regularização de vida escolar, a autenticação de históricos escolares, contagem de tempo, averiguação de sindicâncias e apuração ouvidorias; o acompanhamento de processo de designações e a conferência de documentos com vistas à 
assinatura do formulário "Quadro Informativo Cargo/Função Pública (QI)" antes dos mesmos serem entregues na taxação; e o atendimento de Serviço Especial para verificação 'in loco' em estabelecimentos de ensino particulares que realizam processos de criação, autorização, credenciamento e recredenciamento. Este trabalho é desenvolvido de modo articulado com a DIRE/DIVAE e, de acordo com o tipo de demanda, com a participação de técnicos e analistas vinculados a outros setores da regional (Minas Gerais [2021]).

A SRE de Juiz de Fora possui um total de 20 inspetores escolares (efetivos e designados) para atuar com um quantitativo de 628 escolas, ou seja, uma média de 25 escolas (públicas - estadual e municipal - e particulares) para cada inspetor escolar. Com esse quantitativo enorme de escolas por inspetor é esperado que haja uma precarização do trabalho a ser desenvolvido, sem contar que nem todas as escolas estão no município de Juiz de Fora, já que a SRE de Juiz de Fora tem sob sua jurisdição outros municípios, o que implica no deslocamento do inspetor para outra cidade.

Explicado, em linhas gerais, os cargos que compõem as equipes gestoras, voltaremos à descrição da política dos Itinerários Avaliativos. A primeira etapa desta política dizia respeito à preparação e, por isso, foi oferecida para o diretor e o especialista uma formação em exercício para conhecer a plataforma e planejar a implementação dos itinerários seguintes conforme Figura 8.

Estrutura dos Itinerários Avaliativos de Minas Gerais

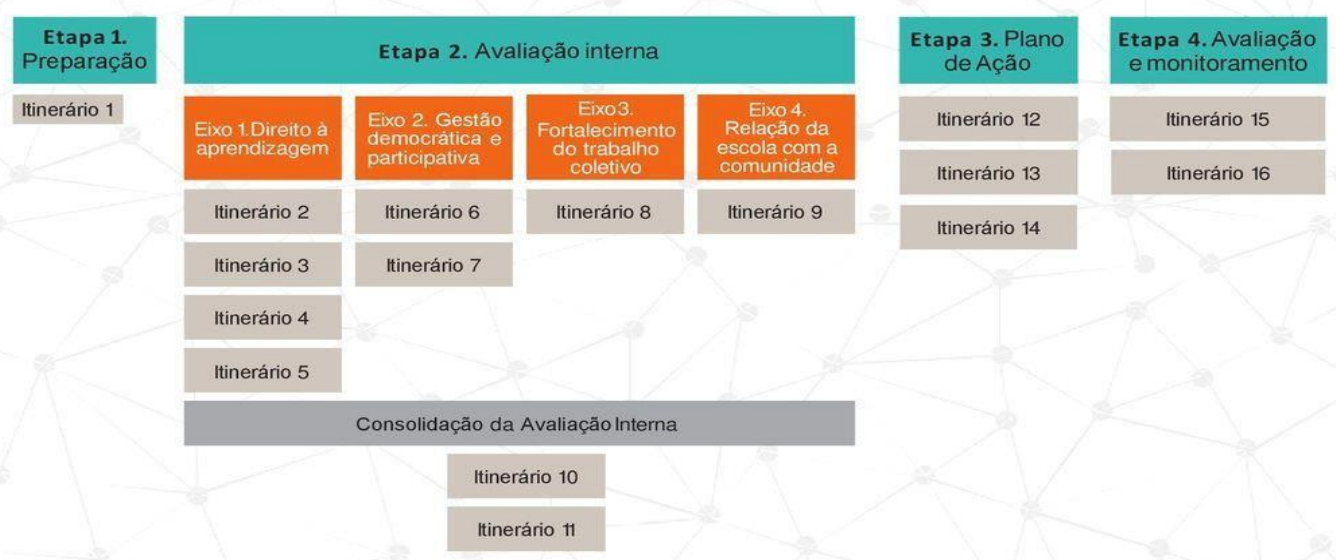

Figura 8 - Itinerários Avaliativos de 2016

Fonte: Protes (2020, p. 41). 
A etapa de avaliação interna estava dividida em 4 eixos que tinham, cada um, seus itinerários. De maneira geral o eixo 1 , direito à aprendizagem, era composto por itinerários cuja finalidade era promover a análise e discussão dos resultados da escola nas avaliações externas, dos seus indicadores de rendimento e fluxo escolar. O segundo eixo, gestão democrática e participativa, era composto por itinerários cujo objetivo era discutir a participação da comunidade no processo de tomada de decisão e o impacto da violência no ambiente de aprendizagem. $\mathrm{O}$ eixo 3 , fortalecimento do trabalho coletivo, promovia o debate sobre 0 engajamento e a participação dos atores escolares e, por fim, o eixo 4 tinha como pauta a discussão sobre a relação entre as famílias e a escola. Cumprido cada um destes eixos e itinerários, as etapas finais diziam respeito à construção e sistematização das discussões por parte da equipe de gestão para posterior apresentação aos professores e à comunidade escolar.

A terceira etapa dizia respeito à construção de um plano de ação a partir de todas as discussões feitas para, em seguida, na quarta etapa, ser planejado o monitoramento e avaliação do referido plano.

O cronograma estabelecido pela SEE/MG para execução dos itinerários mencionados tinha como mês inicial novembro de 2016 e mês final maio de 2017. No entanto, Freitas (2017) e Protes (2020) argumentam que tal política não pode ser implementada e executada conforme o cronograma da SEE/MG primeiro, porque foi uma política implementada de maneira top down e, por isso, não envolveu os atores escolares na discussão do seu planejamento e futura implementação. De acordo com Lotta (2014) o modelo top-down enfatiza a separação entre política e administração, focando no controle e na hierarquia e, por conta disso, a política é feita no topo e executada por agentes implementadores.

Segundo porque, como toda política que chega na escola, ela precisa ser estudada pela equipe gestora para que se torne familiar para aqueles sujeitos que serão os implementadores. Mas como o tempo previsto para esta etapa era o final do ano e do período escolar de 2016, tal preparação ficou comprometida. Por fim, os pesquisadores apontam que os inspetores escolares que atuam junto às escolas ficaram distantes da política dos 
Itinerários Avaliativos, pois não estava prevista sua participação o que, consequentemente, dificultou a oferta de um suporte da regional para a implementação dos itinerários nas escolas.

Passados três anos desta experiência, em 2019, assume a pasta da educação estadual o candidato do partido Novo a SEE/MG retoma a proposta dos Itinerários Avaliativos com o intuito de que as escolas reelaborassem seus Projetos Políticos Pedagógicos (PPP). Esta ação foi consequência da nova política curricular do estado, Currículo Referência de Minas Gerais, construída a partir do Plano Nacional de Educação (20142024) e da Base Nacional Curricular Comum (BNCC) aprovada em 2017. Nesse novo contexto, os Itinerários Avaliativos foram considerados como uma estratégia/metodologia através da qual as escolas discutiriam temáticas relativas às análises de desempenho, à diversidade, à inclusão e ao impacto da violência na aprendizagem. Ou seja, apesar do objetivo da política ser a reformulação do PPP da escola, a sequência dos itinerários pouco se alterou. Na verdade, houve um enxugamento da proposta que passou de 16 itinerários para 13 (ver Figura 9).
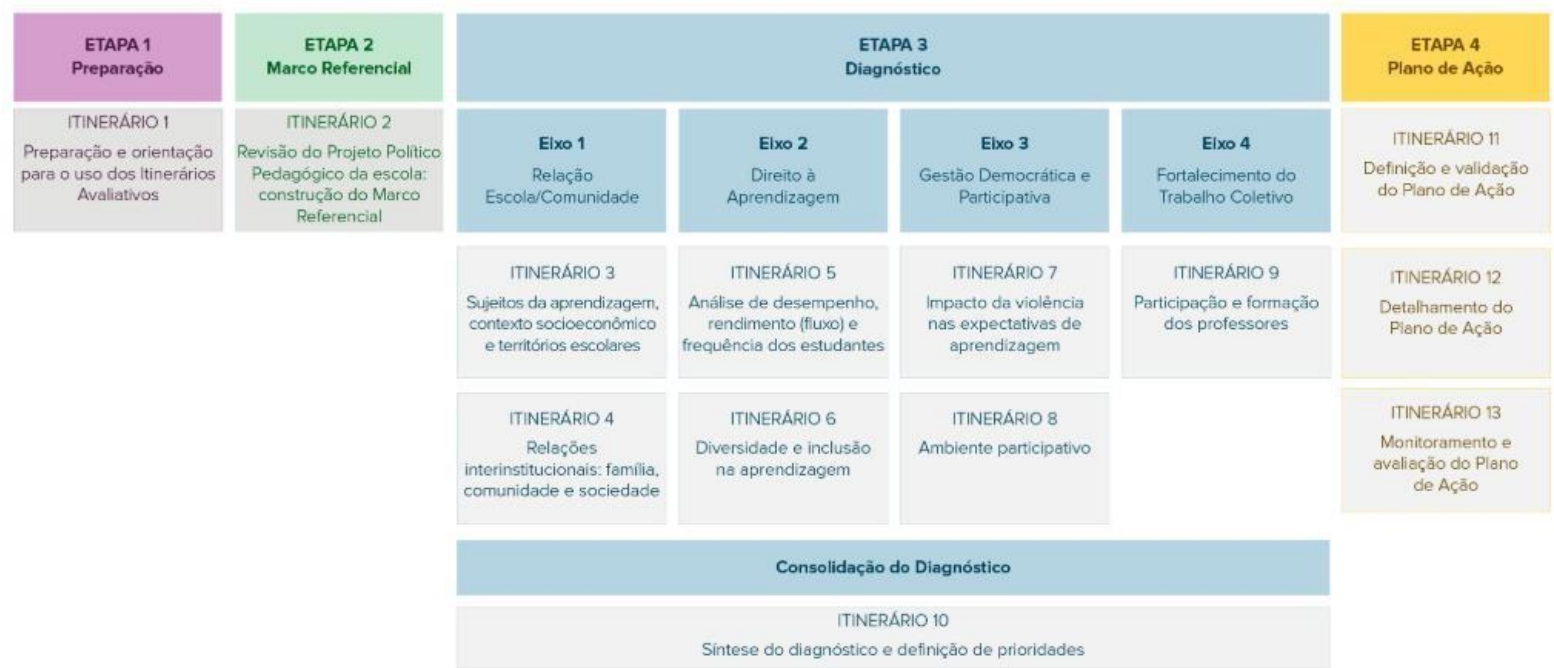

Figura 9 - Itinerários Avaliativos de 2019

Fonte: Protes (2020, p. 49).

Esta segunda versão dos itinerários estava prevista para acontecer durante todo o ano letivo de 2019. Ao final da execução dos itinerários se esperava que as escolas tivessem um esboço daquilo que seria o seu Projeto Político Pedagógico (PPP). De acordo com Protes (2020) todas as 
etapas dos itinerários avaliativos eram registradas eletronicamente pela equipe gestora na plataforma dos itinerários e tais registros eletrônicos foram organizados pela SEE/MG para constituir aquilo que seria um rascunho do PPP da escola. Em fevereiro de 2020, a SEE/MG enviou para as escolas este rascunho do PPP para que elas pudessem verificar se ele estava de acordo com os itinerários feitos e, caso fosse preciso, realizar os ajustes necessários. Porém, em função da pandemia do COVID-19 este processo foi interrompido ${ }^{3}$. Vale destacar que, da mesma forma que na versão anterior do projeto, o órgão regional (SRE) não tinha um papel definido no processo de implementação, novamente o processo ficou sob a responsabilidade dos diretores e especialistas das escolas.

Paralelamente à política dos Itinerários Avaliativos, no mês de agosto de 2019, a SEE/MG firmou uma parceria com o Instituto Unibanco e implementou o Programa Jovem de Futuro. Este programa, em Minas Gerais, tem como foco melhorar os resultados de aprendizagem dos estudantes do Ensino Médio. Para tanto, oferece suporte ao trabalho de gestão nas escolas, como assessoria técnica, formações, análises de dados e sistemas tecnológicos de apoio à gestão escolar (Instituto Unibanco, 2020). A metodologia utilizada no referido programa se baseia no ciclo PDCA (plan, do, check, act) que se desdobra no Circuito de Gestão apresentado na Figura 10.

\footnotetext{
${ }^{3}$ Em função do isolamento social imposto pela pandemia, não foi possível visitar às escolas no resto do ano e acompanhar o processo final relativo aos itinerários. Todavia, a informação recebida das equipes gestoras das escolas é que as discussões continuaram a acontecer de maneira remota.
} 


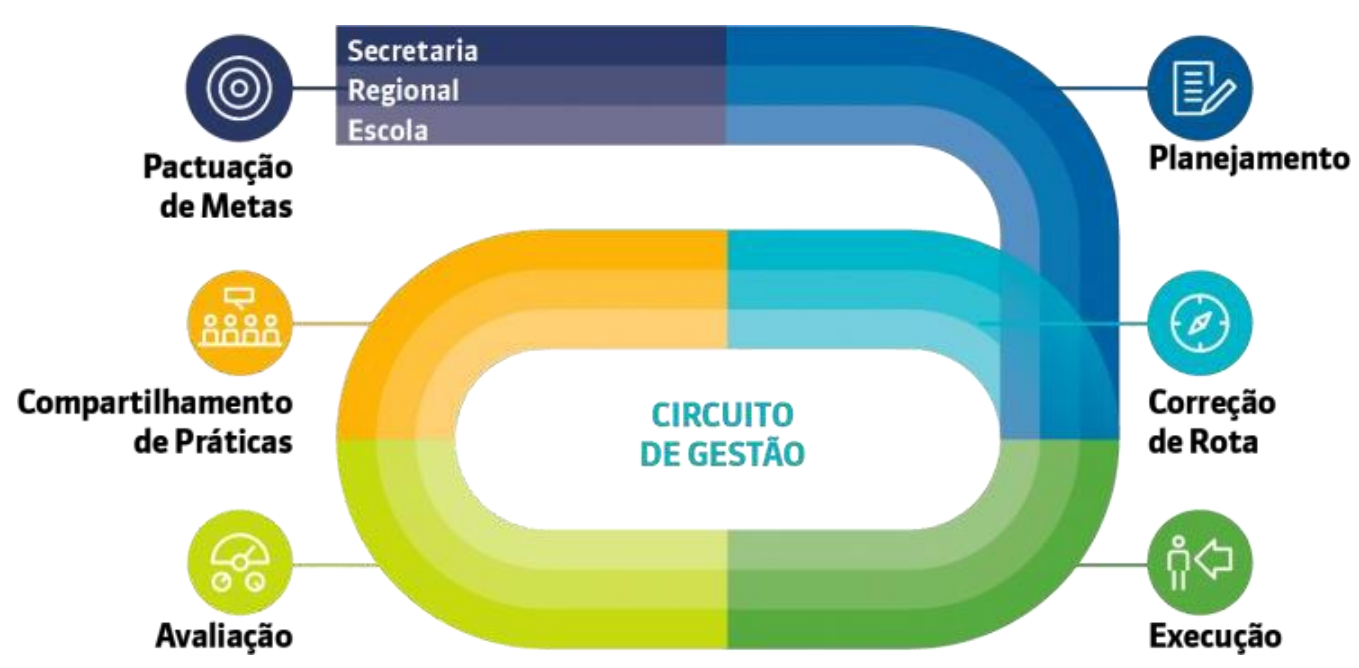

Figura 10 - Circuito de Gestão do Programa Jovem de Futuro Fonte: Instituto Unibanco (2019).

De acordo com o relatório de atividades de Minas Gerais, no ano de 2019 foram feitos, inicialmente, encontros para pactuação e viabilização da proposta junto à SEE/MG. Em seguida foram constituídos três comitês: governança, operacional e tático. Ao primeiro cabia a responsabilidade de analisar e definir metas para o período de 2019 a 2022 para a rede estadual de Ensino Médio; definir a abrangência do programa considerando as fases de implementação; e discutir questões relativas à avaliação de impacto e às formações dos inspetores escolares, gestores, técnicos da SREs e da SEE/MG. O comitê operacional tinha como finalidade solucionar os problemas de implementação e, por fim, o comitê tático tinha como função monitorar a implementação, dadas as dimensões e complexidades da rede de ensino de MG.

Em meados de 2019 foram iniciadas as formações para os superintendentes regionais, inspetores escolares e analistas educacionais da SEE e da SRE, pois eles seriam os responsáveis pela implementação da política e por acompanhar este processo junto às escolas oferecendo, inclusive, suporte. Finalizadas as formações, deu-se início ao processo de implementação do programa nas escolas cujas SREs foram selecionadas ${ }^{4}$. A SRE de Juiz de Fora foi uma das contempladas, assim como as escolas

\footnotetext{
${ }^{4}$ Para maiores detalhes sobre o processo de escolha das SREs acesse o Relatório de Atividades Jovem de Futuro 2019 - MG, páginas 27-28. Disponível em: https://www.institutounibanco.org.br/wp-content/uploads/2020/06/IURelatorio_Atividades_MG_2019-digital.pdf. Acesso em: 08 jan. 2021.
} 
que fizeram parte desta pesquisa. Falaremos sobre como essas políticas foram efetivadas nas escolas mais adiante.

Diante do que expomos nesta seção podemos inferir que a SEE/MG e a SRE de Juiz de Fora constituem um contexto organizacional que oferece recursos (humanos e tecnológicos) e ferramentas (políticas públicas e programas) para que a prática de uso de dados instrucional aconteça nas escolas. Contudo, as pesquisas de Freitas (2017) e Protes (2020) identificaram alguns problemas no processo de efetivação das políticas que dificultaram a sua execução. Atrelado a isso, Farrell (2015) afirma que para compreender o tipo de uso que os dados têm: para fins de investigação e aprendizado profissional ou em direção ao cumprimento de metas de monitoramento e responsabilização, é necessário entender mais especificamente, a relação entre os contextos organizacionais macro (SEE e SRE) e micro (escolas). Por conta disso, na seção seguinte, apresentamos o percurso metodológico desenvolvido para a escolha das escolas, para, em seguida, apresentar seus contextos organizacionais.

\section{2}

\section{A escolha das escolas e a pesquisa de campo}

Nesta pesquisa realizamos uma análise qualitativa, por meio de estudos de caso, sobre como a gestão escolar faz uso dos dados disponibilizados no Sistema Mineiro de Avaliação e Equidade da Educação Pública (Simave) e aqueles provenientes do Sistema Mineiro de Administração Escolar (Simade).

Segundo Yin (2001, p. 32), estudo de caso é uma investigação empírica que "investiga um fenômeno contemporâneo dentro de seu contexto da vida real, especialmente quando os limites entre o fenômeno e o contexto não estão claramente definidos". Por entender que é na escola onde a teoria e a prática são colocadas em jogo, optamos por estudar duas unidades escolares na SRE de Juiz de Fora, considerando que as especificidades de cada contexto poderiam estar relacionadas às diferentes práticas de uso de dados. 
A estrutura da rede estadual de educação de Minas Gerais é descentralizada via Superintendências Regionais de Ensino, as SREs. Ao todo, a rede estadual possui 47 SREs. A escolha da SRE para compor a pesquisa foi feita com base no número de respostas das escolas estaduais ao Survey GESQ5 ${ }^{5}$. Ou seja, selecionamos a SRE com maior número de respostas ao questionário. A SRE de Juiz de Fora foi a regional que apresentou o maior retorno do questionário com 21 respostas ao passo que, nas demais SREs de Minas, 16 escolas ou menos responderam.

Para a escolha das unidades escolares estaduais foi preciso eleger alguns critérios. Todavia, é importante salientar que não houve, necessariamente, uma ordem de aplicação dos mesmos. À medida que analisávamos uma variável, outro aspecto precisava ser levado em consideração e, por isso, a descrição dos critérios que iremos apresentar é resultado de uma escolha metodológica.

O primeiro filtro aplicado para a base inicial de 21 escolas foi selecionar aquelas que estavam localizadas no município de Juiz de Fora e que ofertavam, necessariamente, o Ensino Médio, uma vez que essa é uma obrigação Constitucional dos Estados. A escolha pelas escolas do município de Juiz de Fora justifica-se na medida em que esta é a cidade onde a pesquisadora mora o que era um aspecto relevante para a realização da pesquisa de campo. Feito isso, ficamos com um total de 14 escolas.

O segundo passo foi buscar informações quantitativas e qualitativas para olhar para as 14 escolas. No que diz respeito aos dados quantitativos, levantamos para os anos finais do Ensino Fundamental e Ensino Médio: a média de desempenho em Português e Matemática nas avaliações da Prova Brasil e no Simave no período de 2015 a 2018; o resultado do Ideb nas duas últimas avaliações; o número de matrículas por seguimento; o número de docentes; os turnos de funcionamento, o Índice de Complexidade de Gestão (ICG) ${ }^{6}$ e o Indicador de Nível Socioeconômico

\footnotetext{
${ }^{5}$ Questionário aplicado para todas as escolas estaduais de Minas Gerais e que fizeram parte da pesquisa de doutorado intitulada "Uso dos Dados do Sistema Mineiro de Administração Escolar (Simade) pelos Gestores das Escolas Públicas da Rede Estadual" (LIMA, 2019).

${ }^{6}$ Indicador para mensurar a complexidade da gestão nas escolas a partir dos dados do Censo Escolar da Educação Básica. Para maiores informações sobre o indicador consultar Nota Técnica no 040/2014.
} 
$(\text { Inse })^{7}$, conforme Tabela 1. Quanto aos dados qualitativos buscamos contextualizar as escolas a partir de informações sobre os bairros em que elas estão situadas por meio de informações obtidas no Plano Diretor da Prefeitura e, também, no próprio site da prefeitura, além de notícias publicadas nos meios de comunicação locais (jornais online e redes sociais).

\begin{tabular}{|c|c|c|c|c|c|}
\hline Escolas & ICG & INSE & no matrículas & IDEB/ano/etapa & Região \\
\hline E1 & 4 & 4 & 930 & $4,3 / 2015 / \mathrm{EFII}$ & Noroeste \\
\hline E2 & 4 & $X$ & 373 & $x$ & Noroeste \\
\hline E3 & 4 & 3 & 733 & $\begin{array}{l}\text { 4,8/2015/EFII } \\
3,5 / 2015 / \mathrm{EM}\end{array}$ & Centro \\
\hline E4 & 4 & 3 & 721 & $2,8 / 2017 / \mathrm{EFII}$ & Sul \\
\hline E5 & 4 & $x$ & 922 & 4,5/2015/EFII & Sul \\
\hline E6 & 4 & 3 & 542 & 4,1/2017/EM & Oeste \\
\hline E7 & 4 & $x$ & 443 & $3,2 / 2013 / \mathrm{EFII}$ & Leste \\
\hline E8 & 5 & 4 & 1076 & 2,9/2015/EFII & Leste \\
\hline E9 & 5 & $x$ & 956 & 3,6/2015/EFII & Leste \\
\hline E10 & 6 & 3 & 1037 & 3,9/2013/EFII & Leste \\
\hline E11 & 6 & 3 & 1276 & 4/2017/EFII & Oeste \\
\hline E12 & 6 & 3 & 1401 & $4,2 / 2015 / E F I I$ & Noroeste \\
\hline E13 & 6 & 4 & 3150 & 4,2/2015/EFII & Centro \\
\hline E14 & 6 & 4 & 860 & 2,7/2015/EFII & Leste \\
\hline
\end{tabular}

Tabela 1 - Dados compilados das 14 escolas Fonte: Elaborado pela autora.

Com essas informações em mãos, demos início ao processo de análise de cada uma das 14 escolas. O indicador de nível socioeconômico das escolas tem por objetivo situar o conjunto dos alunos em estratos socioeconômicos, definidos pela posse de bens domésticos, renda e

\footnotetext{
7 As bases para a construção do Inse são os microdados dos questionários contextuais dos participantes do Sistema de Avaliação da Educação Básica (Saeb) e do Exame Nacional do Ensino Médio (Enem). Para maiores informações sobre o indicador consultar Nota Técnica - Indicador de Nível Socioeconômico (Inse) das escolas. Disponível em: http://download.inep.gov.br/informacoes_estatisticas/indicadores_educacionais/2011_2013/nivel_ socioeconomico/nota_tecnica_indicador_nivel_socioeconomico.pdf.
} 
contração de serviços pela família dos alunos e pelo nível de escolaridade de seus pais. Frente a isso, ele representa o contexto econômico e social em que as escolas estão inseridas e, de acordo com Oliveira (2018) e Soares (2006) é um dos principais indicadores educacionais e, por isso, no Brasil não se deve estudar a realidade educacional sem considerá-lo. Diante disso, excluímos as escolas cujo INSE não estava disponível no ano de 2018 e ficamos com um total de 10 escolas. Dentre as escolas com ICG-4 apenas uma tinha INSE igual a 4 e, por isso a excluímos. Dentre as escolas restantes, a SVP tinha número de matrícula muito abaixo das outras o que fez com que ela também fosse excluída. Quanto às escolas do grupo com ICG-5, após a aplicação dos filtros ficamos com apenas uma escola e, por isso, resolvemos retirá-la da amostra. Ficamos, então, com 6 escolas.

Em seguida, passamos a olhar para os números de matrículas e retiramos aquelas escolas cujo número era muito discrepante da maioria, totalizando 4 escolas que fariam parte da pesquisa.

Escolhidas as 4 escolas entramos em contato com a assessora de gabinete da SRE de Juiz de Fora para solicitar a autorização da pesquisa nas escolas. Com a autorização em mãos entramos em contato as escolas e agendamos as visitas para a terceira semana de julho de 2019. Essa era a última semana de aula e, por isso, as escolas estavam mais vazias ofertando apenas atividades de recuperação e jogos de interclasse.

Feita a visita exploratória, decidimos excluir uma das escolas pois, diferentemente das demais, ela funcionava em um prédio alugado pelo Estado (estrutura verticalizada) e, como veremos adiante nas seções sobre liderança e clima escolar, o fator infraestrutura interfere nestes processos e deve ser considerado. No final ficamos com três escolas, que denominaremos de: Travessia, Jardim Botânico e Ladeira.

Iniciamos o campo na escola Travessia, pois tivemos uma maior receptividade, seguida da escola Jardim Botânico e, por fim, a escola Ladeira. A pesquisa de campo nas duas primeiras escolas aconteceu entre agosto de 2019 e fevereiro de 2020. As idas nas escolas durante estes meses foram planejadas para acontecerem em dias da semana diferentes, em turnos diferentes e em momentos específicos planejados no Calendário 
Escolar (ex.:Virada da Educação) para que pudéssemos, na medida do possível, conhecer as diferentes dinâmicas de funcionamento das unidades escolares e as pessoas que ali trabalhavam.

No momento em que iniciamos a observação na escola Ladeira, final de fevereiro e início de março de 2020, iniciou-se a Pandemia causada pelo novo coronavírus (COVID-19) e, em função do isolamento social, a pesquisa de campo nesta escolar teve que ser interrompida. Sendo assim, apresentaremos os dados da pesquisa de campo das escolas Travessia e Jardim Botânico.

Primeiramente, realizamos uma imersão nas escolas por meio de observações do cotidiano da escola e do gestor escolar. Nas observações do cotidiano privilegiamos as atividades que envolviam o gestor escolar e outros membros da equipe gestora tais como: vice-diretores, especialistas, inspeção escolar, ATB e secretária e entre aqueles e os professores, alunos e pais/responsáveis. Após estes momentos e criada uma familiaridade com as pessoas das escolas realizamos entrevistas semiestruturadas com os gestores das escolas, vice-diretores, secretários

e especialistas. Vale ressaltar que, para além das gravações das entrevistas, todas as observações foram registradas no caderno de campo.

$\mathrm{Na}$ seção seguinte apresentaremos os contextos das escolas foco desta pesquisa.

\section{3}

\section{Os contextos das escolas}

De acordo com as explicações feitas até aqui, podemos afirmar que os sujeitos da equipe gestora que compõe a estrutura organizacional da escola são: os diretores, os vice-diretores, os especialistas, o secretário escolar e os ATBs. Dito isso, apresentaremos em seguida, o quadro de pessoal, a infraestrutura e os dados contextuais e de desempenho das escolas foco desta tese cujos critérios de escolha foram apresentados anteriormente.

A escola Travessia está situada na região Sudeste de Juiz de Fora e a escola Jardim Botânico fica na região Norte (ver Figura 11). Apesar de 
estarem em regiões distintas, ambas situam-se em Zonas de Especial Interesse Social (ZEIS) o que significa que é uma área de zoneamento de população de baixa renda que precisa ser urbanizada e regularizada (Juiz de Fora, 2000). Na escola Travessia $80 \%$ dos alunos são beneficiários do Bolsa Família enquanto na escola Jardim Botânico são 60\%. Aqui vale uma ressalva, uma vez que a escola Travessia atende alunos provenientes das quatro comunidades mais pobres de Juiz de Fora.

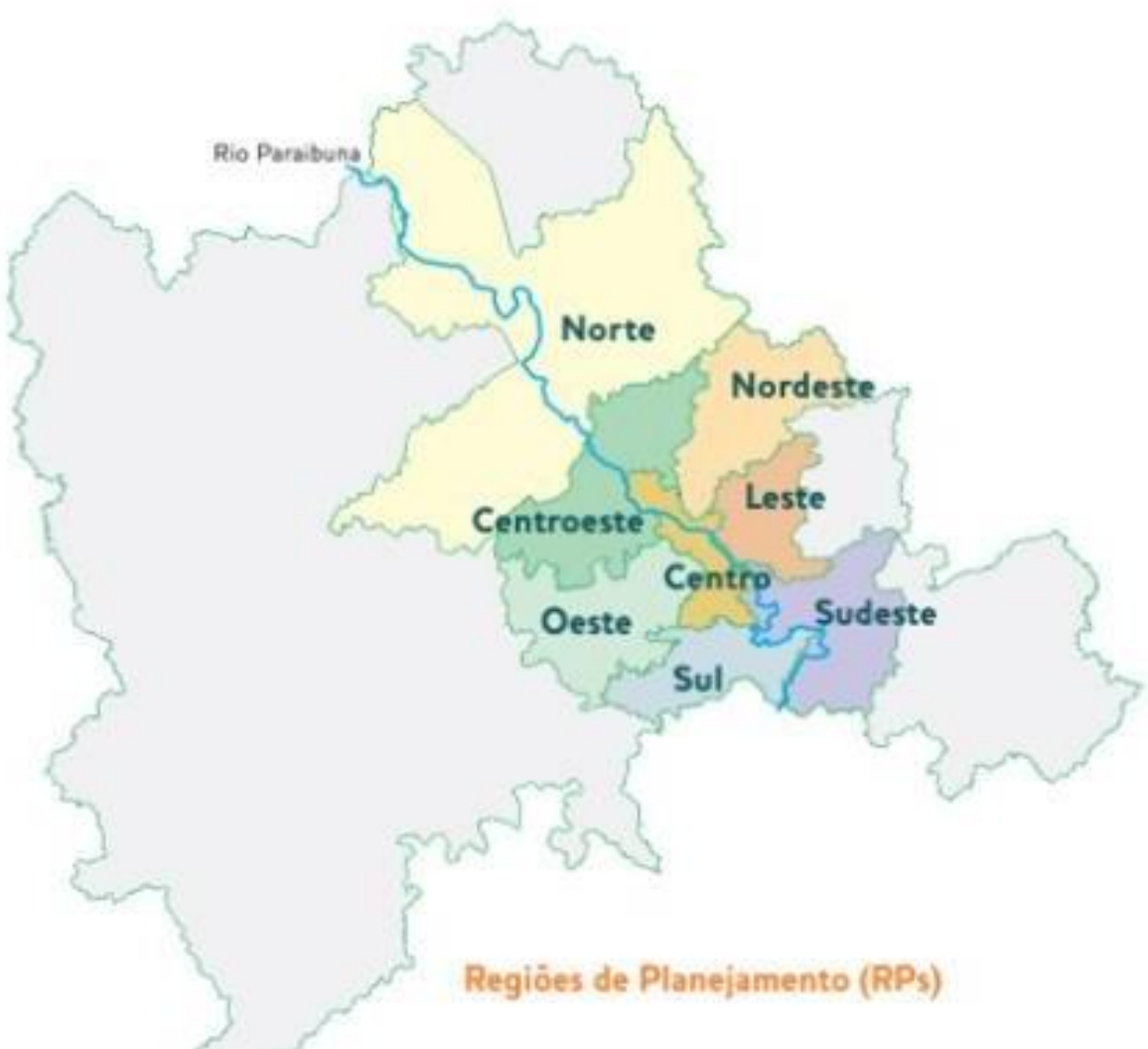

Figura 11 - Mapa com as Regiões de Juiz de Fora Fonte: Juiz de Fora (2019).

De acordo com os dados de $2018^{8}$ do Censo Escolar, disponíveis no Quadro 1, a escola Travessia possui:

\footnotetext{
${ }^{8}$ A seleção das escolas para a pesquisa foi feita no ano de 2018 , por esta razão os dados inicialmente levantados são do Censo Escolar de 2018. Em 2020, tais informações foram revistas e pudemos constatar que não houve alterações significativas.
} 


\begin{tabular}{|l|c|}
\hline \multicolumn{1}{|c|}{ Informações } & Escola Travessia \\
\hline Índice de Complexidade de Gestão* & 6 \\
\hline INSE & 4 \\
\hline № matrículas & 667 \\
\hline № funcionários & 75 \\
\hline № docentes & 64 \\
\hline Turnos de funcionamento & manhã, tarde e noite \\
\hline
\end{tabular}

Quadro 1 - Dados gerais da escola Travessia

Fonte: Elaborado pela autora a partir de dados fornecidos pela secretaria da escola (2020).

* Índice cuja escala varia de 1 a 6. Nível 6 - Escolas que, em geral, possuem porte superior a 500 matrículas, funcionam em 3 turnos, com oferta de 4 ou mais etapas de ensino e apresentam a EJA.

Os dados apontam que a escola tem uma alta complexidade de gestão, atende a alunos cuja renda familiar mensal está entre 1,5 e 5 salários mínimos e cujos pais ou responsáveis possuem ensino fundamental completo ou estão cursando esse nível de ensino.

A diretora da escola Travessia, formada em licenciatura em história, é funcionária concursada na rede estadual e, antes de ser diretora, era professora de história na escola. Ela está há 6 anos no cargo de direção. Seu primeiro mandato foi uma indicação da SRE de Juiz de Fora em função do diretor anterior ter sido da exonerado pela SEE/MG em função de problemas na prestação de contas da escola. Concluído o $1^{\circ}$ mandato ela concorreu a eleição e foi eleita e reeleita consecutivamente para um $2^{\circ}$ e $3^{\circ}$ mandato (atual), respectivamente, pela comunidade escolar. Segundo o relato da diretora, a princípio, a escola tinha muitos problemas com violência em função do público atendido e ela buscou construir uma identidade dos alunos com a escola desenvolvendo um sentimento de pertencimento à escola. Além disso, ela conta que ajudou a criar o grêmio estudantil da escola que oferece ações para os alunos como, por exemplo, o cineclube no turno da noite.

Em Minas Gerais, a quantidade de pessoal que as escolas podem ter depende do número de matrículas e, consequentemente, do número de turnos que será ofertado. A escola Travessia oferta três turnos, sendo o Ensino Fundamental II (6 ao 9ำ ano) e o Ensino Médio no turno da manhã, o Ensino Fundamental I ( $1^{\circ}$ ao $5^{\circ}$ ano) à tarde. À noite a escola oferece 0 $1^{\circ}$ e $2^{\circ}$ ano regular do Ensino Médio e Educação de Jovens e Adultos I, II e III. Ao todo a escola possui 75 funcionários dentre Assistentes Técnicos de 
Educação Básica (ATBs), Auxiliares de Serviços da Educação Básica $(\mathrm{ASBs})^{9}$ e professores. O corpo docente da escola é formado por 64 professores dos quais 23 são efetivos e 41 são contratados, isto é, mais da metade dos professores possuem vínculo temporário com duração de um ano com a escola.

A escola conta com três especialistas das quais, uma atua na escola no período da manhã (EFII e EM), outra à tarde e à noite $(E F I)$ e a terceira atua na extensão rural; e dois vice-diretores. A escola possui outros dois endereços nos bairros Milho Branco e Valadares (escola rural), chamados de extensão, nos quais oferta o Ensino Médio em escolas da prefeitura.

No Quadro 2 apresentamos os cargos, o tipo de contrato com a escola e a formação das pessoas da equipe gestora.

\begin{tabular}{|l|l|l|}
\hline \multicolumn{1}{|c|}{ Cargo na escola } & \multicolumn{1}{|c|}{ Tipo de contrato } & \multicolumn{1}{c|}{$\begin{array}{c}\text { Grau mais alto de } \\
\text { formação }\end{array}$} \\
\hline Direção & 1 Efetivo & Especialização \\
\hline Vice direção & 2 Efetivos & Graduação \\
\hline Especialista & $\begin{array}{l}1 \text { Efetivo } \\
2 \text { Contratos temporários }\end{array}$ & $\begin{array}{l}\text { Especialização } \\
\text { Especialização } \\
\text { Graduação }\end{array}$ \\
\hline ATB & $\begin{array}{l}\text { 3 Contratos temporários } \\
1 \text { Efetivo }\end{array}$ & Curso técnico \\
\hline Secretária & 1 Efetivo & Graduação \\
\hline ATB Financeiro & 1 Contrato temporário & Especialização \\
\hline
\end{tabular}

Quadro 2 - Cargos, tipos de contrato e formação do pessoal da escola Travessia Fonte: Elaborado pela autora a partir de dados fornecidos pela secretaria da escola.

Como mostra o Quadro 2, metade da equipe gestora da escola é efetiva e metade é contratada. Os contratos têm validade de um ano, ao fim do qual é necessário realizar novamente o processo de contratação. Por conta disso, não há garantias de que as mesmas pessoas retornarão no ano seguinte. Em termos administrativos essa situação só não é mais grave porque os servidores contratados trabalham em setores em que há profissionais efetivos e, por isso, mesmo que não voltem para a escola no ano seguinte, o setor terá alguém ciente do que foi feito. Outra vantagem de ter efetivos em todos os setores é que os contratados temporariamente podem recorrer a eles para saber alguma informação e tirar dúvidas.

\footnotetext{
${ }^{9}$ Responsáveis pelos serviços gerais da escola.
} 
Todavia, vale ressaltar que a única especialista efetiva possui atua na escola desde 2017 e possui um cargo de $24 \mathrm{~h}$ semanais para atuar junto aos professores do Ensino Fundamental II e do Ensino Médio, se reunir com a equipe gestora e com os outros especialistas da escola. Os especialistas têm, a princípio, muita demanda de trabalho e, no caso desta escola, durante a observação foi possível perceber que eles gastavam a maior parte do tempo resolvendo problemas disciplinares dos alunos o que, consequentemente, limitava ainda mais o tempo usado para fazer face às demandas pedagógicas como reuniões da equipe de especialistas com os professores para pensar o planejamento curricular e desenvolver ações pedagógicas na escola, conforme o especialista 2:

\footnotetext{
Olha, meu dia a dia é corrido. Porque eu chego na escola e procuro saber se a direção tem algum repasse para me passar. Tem um e-mail específico que o estado entra em contato com os supervisores, então a gente confere diariamente para ver se tem alguma novidade. E fico rodando de sala em sala, tentando achar aluno que tá matando aula, que tá passeando pela escola, que tá fazendo outras coisas. Às vezes eu sou chamado nas salas para poder resolver alguma pendência, ou para poder ajudar algum professor também. E o meu dia a dia é essa rotatividade. (Especialista 2. Entrevista realizada em agosto de 2019)

A especialista (da manhã) eu não encontro muito, infelizmente porque nosso turno não bate. Ela também tem vários cargos, então ela também vem na mesma correria que eu. A gente se encontra nos dias que são comuns aos dois, que são os dias de módulo ou de sábado letivo. Aí a gente acaba se esbarrando e conversa. (Especialista 2. Entrevista realizada em agosto de 2019)
}

Outra ressalva necessária diz respeito à ATB que trabalha na administração financeira e cujo contrato com a escola era temporário. A diretora delegava a ela todo o trabalho administrativo-financeiro (realizar compra da merenda escolar, fazer controle financeiro dos montantes da Caixa Escolar, realizar pagamentos de serviços prestados na escola, etc.) da escola, reservando a si o papel de verificar o que era feito, opinar sobre as compras e assinar os contratos e pagamentos. Apesar de trabalhar na escola há seis anos, a referida ATB anualmente passa pelo processo de contratação do Estado, ou seja, todo ano ela tem que se inscrever no processo seletivo público para ser designada para trabalhar em determinada escola. A designação para qual escola os candidatos irão trabalhar segue a seguinte ordem de critérios: i) ser concursado para o município ou SRE e ainda não ter sido nomeado; ii) ser concursado para 
outro município ou outra SRE e ainda não ter sido nomeado; iii) estar inscrito e habilitado, obedecida a ordem de classificação (tempo de trabalho na rede, titulação) na listagem geral do município. No caso da ATB financeira da escola Travessia ela se enquadra no terceiro critério, sendo assim, caso haja outro candidato que preencha os critérios i ou ii e queira ir para a escola Travessia, ele terá preferência. Isso é um problema na medida que a atual ATB é quem exerce a parte administrativa/financeira da escola, conhece a receita da escola e realiza todos os processos de compra de merenda e materiais de uso contínuo, entre outras atividades.

Durante a pesquisa, frente ao comentário da ATB financeira de que quase não conseguiu ser lotada na escola no último processo de designação da SEE (ano de 2019), a diretora se mostrou visivelmente preocupada e alterada, por não saber "lidar com essa parte e precisar" desta ATB financeira na escola. De fato, durante toda a pesquisa de campo, as situações que envolviam compras, pagamentos de serviços, prestação de contas e licitação eram administradas pela referida ATB.

A escola Jardim Botânico, semelhante à escola Travessia, possui alto índice de complexidade de gestão e INSE próximos. A escola também funciona em três turnos e oferta o Ensino Fundamental anos finais e Ensino Médio de manhã e à tarde o Ensino Fundamental anos iniciais e o EJA à noite. No Quadro 3 apresentamos algumas informações da escola referentes ao ano de 2018.

\begin{tabular}{|l|c|}
\hline \multicolumn{1}{|c|}{ Informações } & Escola Jardim Botânico \\
\hline ICG & 6 \\
\hline INSE & 3 \\
\hline № matrículas & 1132 \\
\hline № funcionários & 85 \\
\hline № docentes & 61 \\
\hline Turnos de funcionamento & Manhã, tarde e noite \\
\hline
\end{tabular}

Quadro 3 - Dados gerais da escola Jardim Botânico

Fonte: Elaborado pela autora a partir de dados fornecidos pela secretaria da escola.

Na escola Jardim Botânico o diretor iniciou sua trajetória na equipe gestora em 2008, como vice-diretor. Em 2010, após aprovação no exame de certificação, ele concorreu ao cargo de diretor e foi eleito para seu 
primeiro mandato. No ano de 2019 o diretor está cumprindo seu terceiro mandato.

O diretor da escola Jardim Botânico é formado em licenciatura em Letras, mas diferente da gestora da escola Travessia seu contrato com a SEE/MG é temporário. Isso significa que ele não é efetivo no Estado e, por isso, para se candidatar ao cargo de gestor escolar ele precisava estar a mais de dois anos lotado na escola e passar na prova de certificação. De todo modo, todo ano ele precisa participar do processo de designação do Estado para ficar lotado em alguma escola.

Em uma das entrevistas o diretor afirmou que, no início da sua gestão, a escola tinha problemas com a violência e que os resultados de aprendizagem eram ruins. Segundo ele, a partir de um trabalho coletivo foi possível reverter essas situações na escola que atualmente melhoraram muito:

[...] nossos resultados externos deixaram muito a desejar, mas em seis anos eu consegui mudar muita coisa na escola sabendo que nunca sozinho sempre com uma equipe [...] o nível de violência diminuiu bem. (Diretor Jardim Botânico).

O corpo docente da escola é formado por 61 professores dos quais 41 são efetivos e 20 são contratados, isto é, ao contrário da escola Travessia mais da metade dos professores possuem vínculo efetivo com a escola.

A escola conta com duas especialistas das quais, uma atua na escola no período da manhã (EFIl e EM), outra à tarde e à noite (EFI e EJA); e três vice-diretores (uma para ada turno da escola).

No Quadro 4 são apresentados os cargos, os tipos de contratos e o maior grau de formação da equipe gestora da escola. 


\begin{tabular}{|l|l|l|}
\hline \multicolumn{1}{|c|}{ Cargo na escola } & \multicolumn{1}{|c|}{ Tipo de contrato } & \multicolumn{1}{c|}{$\begin{array}{c}\text { Grau mais alto de } \\
\text { formação }\end{array}$} \\
\hline Diretor & Contrato temporário & Especialização \\
\hline Vice (manhã) & Contrato temporário & Graduação \\
\hline Vice (tarde) & Efetivo & Graduação \\
\hline Vice (noite) & Contrato temporário & Graduação \\
\hline Especialista (manhã) & Efetivo & Doutorado em Educação \\
\hline Especialista (tarde) & Efetivo & Graduação \\
\hline ATB secretaria & 2 Efetivos & Curso técnico \\
\hline Secretário & Efetivo & Graduação \\
\hline ATB Financeiro & Contrato temporário & Curso técnico \\
\hline
\end{tabular}

Quadro 4 - Cargos, tipos de contrato e formação do pessoal da escola Jardim Botânico

Fonte: Elaborado pela autora a partir de dados fornecidos pela secretaria da escola.

Os dados do Quadro 4 mostram que, assim como na escola Travessia, metade da equipe gestora é contratada e metade é efetiva. $A$ diferença reside, contudo, nos cargos pois se na escola Jardim Botânico o diretor, dois vice diretores e o ATB financeiro são contratados temporariamente, na escola Travessia esse tipo de vínculo concentra-se nos cargos de especialistas e ATBs. A especialista que atua no turno da manhã na escola Jardim Botânico também possui cargo de $24 \mathrm{~h}$ e, assim como a especialista da escola Travessia, tem as mesmas demandas de trabalho. Entretanto, como as duas escolas possuem climas escolares bem distintos, como veremos mais adiante, a rotina de trabalho e as relações com os demais membros da equipe gestora são diferentes.

Outra convergência está no fato de a ATB financeira da escola Jardim Botânico também ter contrato temporário, mas diferentemente da diretora da escola Travessia, o diretor da escola Jardim Botânico é quem gerencia a parte administrativa-financeira e, por isso, cabe à ATB financeira apenas auxiliá-lo nas tarefas relativas a esse tipo de demanda.

Tanto a escola Jardim Botânico quanto a escola Travessia possuem infraestruturas parecidas, conforme o padrão de construção das escolas estaduais de Minas Gerais (ver Apêndices B e C). Ambas atendem alunos de comunidades próximas às escolas e as situações de violência eram comuns às duas no início da gestão dos respectivos diretores. Além disso, as escolas possuem salas de informática com computadores de uso coletivo. Enquanto na escola Travessia a maioria dos computadores de uso coletivo não funcionava, na escola Jardim Botânico os computadores 
funcionavam e tinham acesso à internet. Os computadores de uso da secretaria funcionam em boas condições em ambas as escolas. Vale ressaltar, entretanto, que o diretor da escola Jardim Botânico tinha um notebook de uso pessoal e cada especialista tinha um computador disponível para uso. Na escola Travessia havia um único computador que ficava na sala dos especialistas e que era usado pelos professores, pelas especialistas e pela direção e vice direção.

Quanto à conexão à internet, na escola Travessia era usado o pacote de dados fornecido pela SEE/MG; já na escola Jardim Botânico além do pacote de dados da SEE/MG, havia um pacote extra de dados e wi-fi disponível para professores e demais funcionários da escola que era financiado com verba da Caixa Escolar. De todo modo, os secretários e membros da equipe gestora das duas escolas consideram que a conexão com à internet é boa o suficiente para acessar o Simade, Diário Escolar Digital (DED) ${ }^{10} \mathrm{e}$ Simave. Os poucos problemas relatados diziam respeito aos momentos de lançamento de dados próximos ao prazo final quando o grande número de acessos tornava os sistemas mais lentos.

Nas duas escolas a função de inserir e atualizar os dado ${ }^{11}$ no Simade, bem como fazer uso deles para extrair relatórios (ex. aprovação e reprovação) e documentos (ex. histórico escolar, declaração de matrícula) ficava a cargo dos secretários escolares e ATB's. Durante as entrevistas estes disseram que, apesar do uso diário do sistema, nunca tinham participado de uma formação para aprender a usar o sistema e, por isso, o aprendizado aconteceu, na maior parte das vezes, através de trocas de experiências com pessoas que já utilizavam o sistema e pelo próprio uso do sistema. Disseram ainda, que caso tivessem dúvidas que os colegas não soubessem responder, eles entravam em contato com o Serviço de Documentação e Informação Educacional (Sedine) da SRE, responsável pelo monitoramento e atualização de dados escolares das unidades de

\footnotetext{
${ }^{10}$ O DED é um sistema vinculado ao Simade. A secretaria da escola alimenta o Simade com dados das turmas e alunos e essas informações migram para o DED. No DED os professores visualizam as turmas e os alunos e realizam os lançamentos de frequência, notas e conteúdos trabalhados. Após o fechamento do bimestre esses dados migram para o Simade.

${ }_{11}$ Dados educacionais relativos ao cadastro do aluno, à matrícula, à enturmação, à aprovação, à reprovação, à evasão e ao abandono.
} 
ensino no Simade e no DED, mas que nem sempre obtinham respostas rapidamente.

Os diretores das escolas, por sua vez, acessavam o Simade de maneiras distintas. $O$ diretor da escola Jardim Botânico acessava o sistema todos os dias quando chegava na escola. Sua rotina era chegar na escola e acessar o e-mail e o Simade para verificar as demandas diárias e, a partir disso, planejar o seu dia. Seu planejamento semanal previa reuniões com a equipe gestora e com a ATB financeira. Durante a observação na escola pude acompanhar tais reuniões que eram previamente preparadas pelo diretor da escola. Ele definia a pauta a partir de demandas que ele recebia da SRE e dos demais membros da equipe gestora e a enviava por e-mail para as pessoas que participariam na reunião. O planejamento mensal do diretor previa reuniões com o Conselho Escolar, cuja pauta - também preparada previamente pelo diretor - era apresentada no início da reunião e, em seguida, era aberto espaço de fala para os presentes se manifestarem e inserirem outros assuntos, caso achassem necessário.

A diretora da escola Travessia raramente acessava o Simade ou o email da escola. Sua rotina era chegar na escola e receber as demandas cotidianas via vice direção, secretaria, especialista ${ }^{12}$ e/ou ATB financeira da escola. Tais demandas eram majoritariamente relativas à assinatura de documentos e/ou situações que envolviam problemas disciplinares de alunos. Não havia uma programação de reuniões entre os membros da equipe gestora e entre a direção e a secretaria/ATBs. Durante a realização da pesquisa não houve nenhuma reunião com o Conselho Escolar que a pesquisadora tenha tido ciência. A dinâmica do trabalho da gestão da escola era desenhada por demanda. Uma situação que ilustra esta constatação foi verificada quando, após o prazo para lançamentos das informações sobre as aulas e os alunos no DED, a especialista avisou a diretora que uma professora não havia lançado os conteúdos lecionados e, tampouco a presença dos alunos e que isso precisava ser feito. Foi naquele momento, em função da demanda apresentada, que elas sentaram juntas para pensar em como resolver o problema. A solução encontrada foi

\footnotetext{
${ }^{12} \mathrm{O}$ cargo de especialista de educação básica envolve a orientação, o acompanhamento, a implementação e a avaliação do processo de ensino-aprendizagem na escola.
} 
primeiro entrar em contato com a professora para pedir que ela fizesse 0 lançamento no DED naquele dia e, caso isso não fosse possível, elas mesmas fariam o lançamento a partir das informações que a professora repassaria.

As observações feitas no cotidiano das escolas dialogam com os achados da pesquisa de Lima (2019) que buscou compreender o uso do Simade pela equipe gestora nas escolas estaduais de Minas Gerais e, para tanto, coletou 586 respostas por meio de questionário aplicado para diretores, secretários e ATBs. Da mesma forma que Lima (2019) verificamos que quem usa esse sistema no dia a dia da escola são os diretores, secretários e ATBs. Embora cada um deles pudessem fazer usos distintos das ferramentas disponíveis no sistema devido às permissões relacionadas aos logins, os usos estavam sempre atrelados às demandas administrativas e, no caso específico do diretor, ele supervisionava, via sistema, o trabalho realizado pelos profissionais da secretaria. Diferentemente do esperado, em nenhuma das duas escolas os diretores usavam os dados relativos ao fluxo e desempenho do Simade, por exemplo, para tomar decisões e/ou planejar ações pedagógicas.

$\mathrm{Na}$ escola Travessia a principal fonte de informação sobre a presença dos alunos na escola era a observação diária que acontecia por parte da diretora e do vice-diretor. Ou seja, eles observavam os alunos na hora da entrada e no horário do recreio e ficavam sabendo quem ia ou não à escola. De acordo com o especialista e o vice-diretor:

A (diretora), principalmente, é muito mãezona e... é uma coisa engraçada porque as crianças que a gente atende hoje são filhos de ex-alunos da escola. Então, assim, ela conhece quase toda a comunidade que frequenta a escola. (Especialista 2 . Entrevista realizada em agosto de 2019).

É nós temos aí (...) quase 15 anos como unidade então a gente conhece do avô do pai do menino e o menino que já teve filho, então a gente sabe o cotidiano desse menino, a gente conhece as famílias então a gente sabe porque o menino parou. Ah ela ficou grávida, ah ela teve que mudar de bairro por causa de alguma ameaça e agora retornou para o bairro. Então a gente acaba sabendo da vida do aluno então a gente tem essa entrada de tentar fazer o retorno desse menino ou dessa família para dentro da escola novamente... é o conhecimento da comunidade, que vem com tempo né. (Vice Diretor. Entrevista realizada em setembro de 2019). 
Também na escola Jardim Botânico o controle da presença era feito de maneira pouco formal, mas, neste caso, era através dos representantes de turmas. Ou seja, cada sala tinha um representante que ficava responsável por registrar acontecimentos gerais da turma e anotar quem faltava aula. Depois eles repassavam essas informações para as especialistas ou para os vice-diretores que, cientes da ausência, ligavam para casa do aluno para saber por que ele havia faltado à aula.

No que tange à formação para uso do Simade a pesquisa de Lima (2019) identificou que somente $39,5 \%$ dos diretores e $55,8 \%$ dos secretários/ATBs fizeram qualquer capacitação no período de 2016 a 2018 e que as mesmas aconteceram de forma esporádica para sanar dúvidas pontuais e tiveram uma carga horária insuficiente em relação à quantidade de informações a serem repassadas. Como relatamos, nenhum secretário, ATB ou diretor das escolas desta pesquisa participou de formação sobre o Simade.

Passaremos, a seguir, para a apresentação dos dados educacionais sobre desempenho na Prova Brasil, indicador de rendimento ${ }^{13}$, índice de desenvolvimento da educação básica (Ideb) e distorção idade-série das escolas para, depois apresentar os dados referentes à avaliação do Simave. No Gráfico 1 está representado a série histórica do Ideb do 9o ano do Brasil, de Minas Gerais e das escolas que participaram da pesquisa.

\footnotetext{
${ }^{13} \mathrm{O}$ indicador de rendimento usado na formula do Ideb para uma determinada etapa é uma composição das taxas de aprovação de cada uma das séries que a compõem e varia de zero a um (FONSECA, 2010).
} 


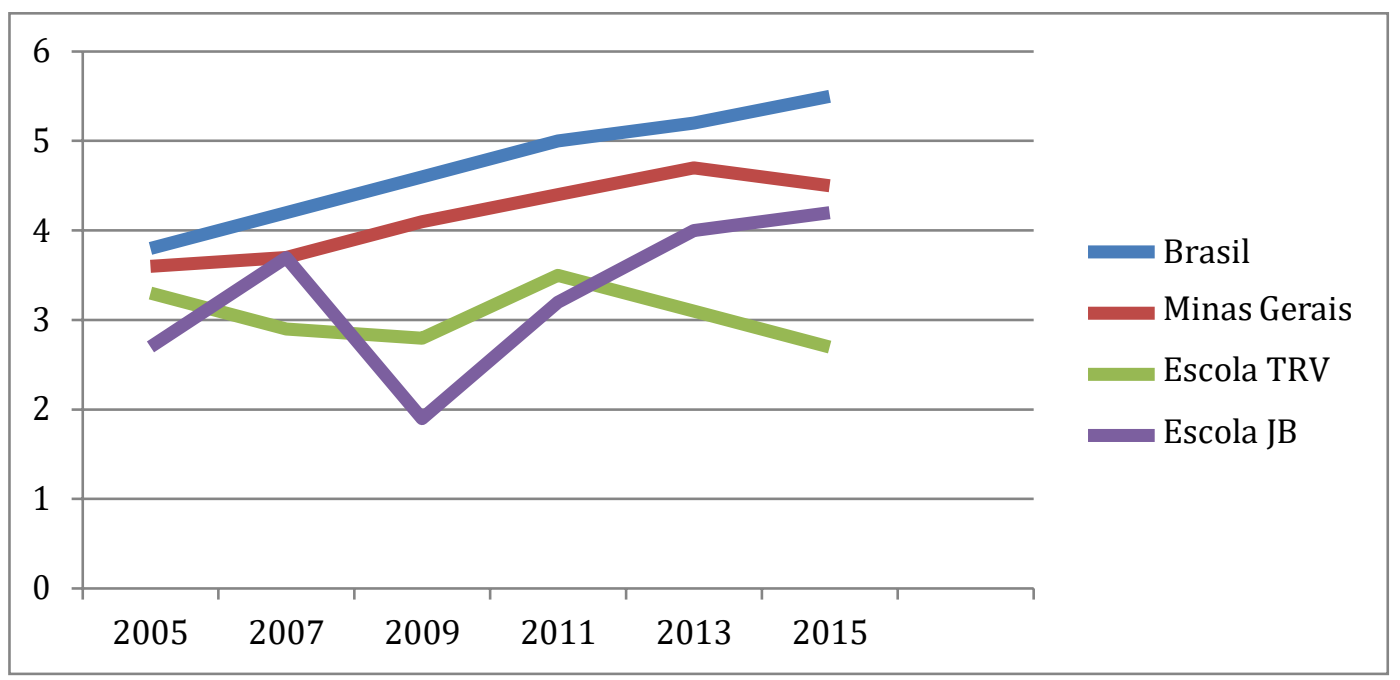

Gráfico 1 - Série histórica do Ideb/9ำ ano - Brasil, Minas Gerais, Escolas Travessia e Jardim Botânico

Fonte: Elaborado pela autora com base nos dados do Inep (2020).

Os dados apresentados no Gráfico 1 indicam que as escolas possuem Ideb abaixo do estadual e do nacional. A escola Travessia, contudo, apresenta desde 2011, uma tendência de queda no Ideb enquanto a escola Jardim Botânico, no mesmo período, mostra crescimento no referido índice.

O Ideb é o principal indicador da qualidade da educação básica no Brasil. Em uma escala de 0 a 10, sintetiza dois conceitos, o indicador de rendimento (aprovação escolar) e o aprendizado em português e matemática (média de desempenho na Prova Brasil) (Lemann \& Meritt, 2020). Por conta disso, apresentaremos nos Gráficos 2, 3 e 4 os dados referentes ao indicador de rendimento e médias de desempenho na Prova Brasil ${ }^{14}$ nas disciplinas de língua portuguesa e matemática de cada escola, respectivamente.

${ }^{14} \mathrm{O}$ intervalo entre os valores do eixo $X$ corresponde aos mesmos intervalos da escada de proficiência da Prova Brasil. Sendo assim, cada intervalo de 25 pontos na escala corresponde a um padrão de desempenho. 


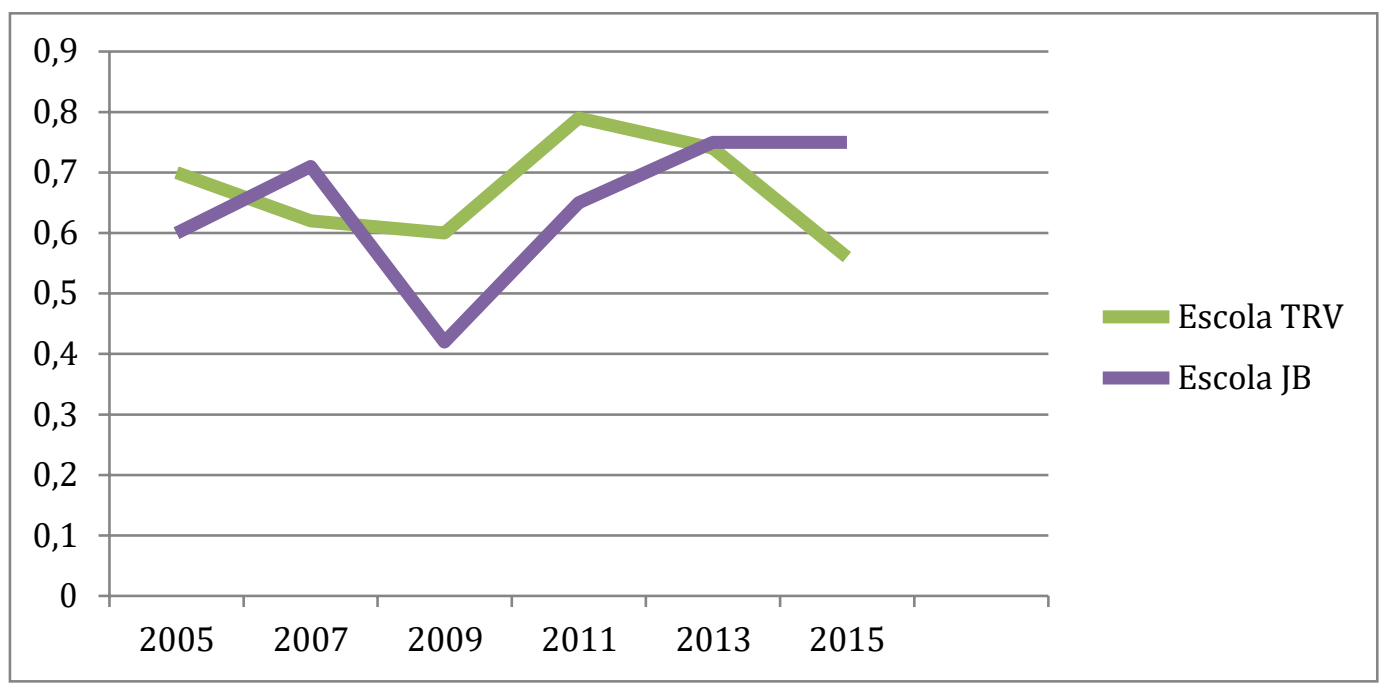

Gráfico 2 - Indicador de Rendimento (taxa de aprovação)/9ªno das escolas Fonte: Elaborado pela autora com base nos dados do Inep (2020).

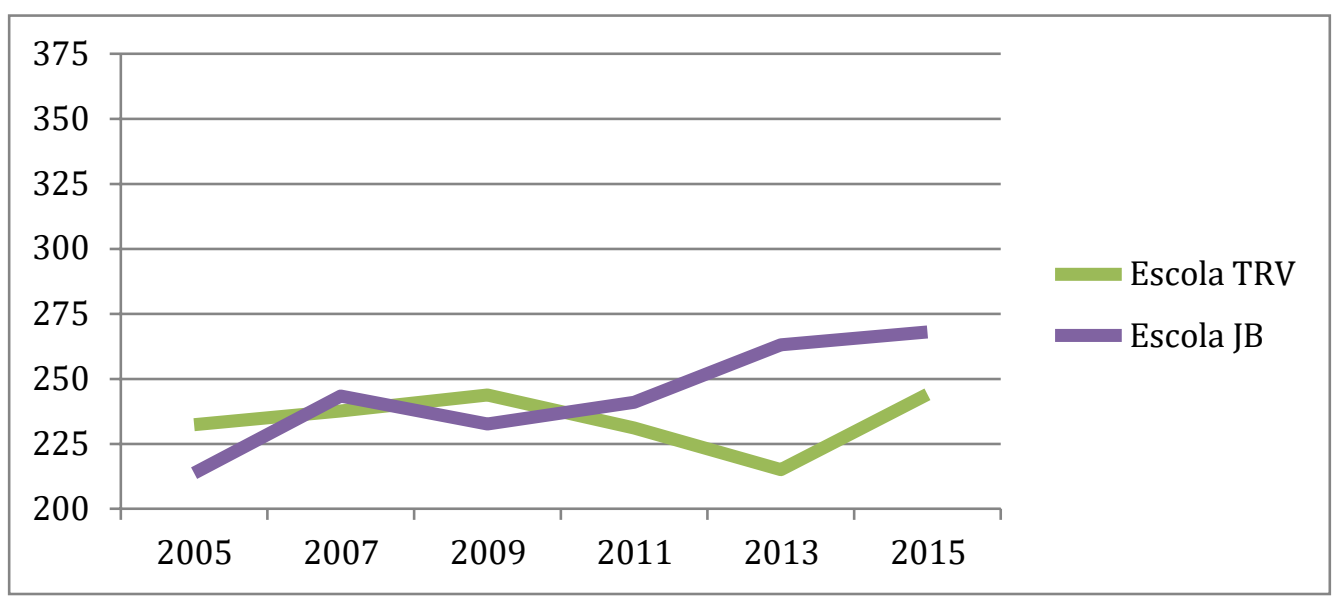

Gráfico 3 - Média de proficiência das escolas na Prova Brasil em Língua Portuguesa $/ 9^{\circ}$ ano

Fonte: Elaborado pela autora com base nos dados do Inep (2020).

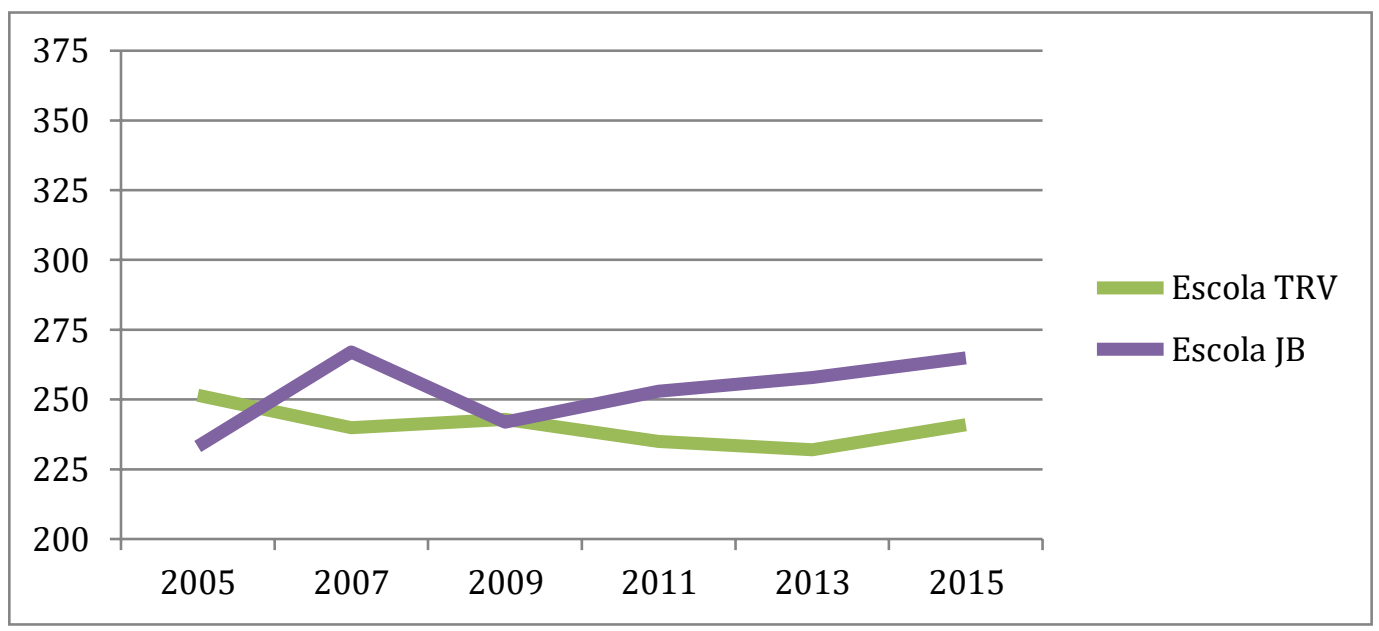

Gráfico 4 - Média de proficiência das escolas na Prova Brasil em Matemática/9ano Fonte: Elaborado pela autora com base nos dados do Inep (2020). 
Como mostram os dados apresentados nestes gráficos, desde 2009, a taxa de aprovação da escola Travessia vem diminuindo e, apesar das oscilações nas médias de proficiência na Prova Brasil, a escola permanece no mesmo nível da escala de proficiência nas duas disciplinas avaliadas, ou seja, no nível 2 (numa escala que varia de nível 1 a nível 8 para língua portuguesa e de nível 1 a nível 9 para matemática). Consequentemente, o Ideb vem apresentando uma tendência de queda. Já a escola Jardim Botânico apresentou, no mesmo período, um aumento na taxa de aprovação e uma mudança de nível na escala de proficiência tanto de língua portuguesa quanto de matemática, que passou de nível 2 para nível 3. Diante disso, o ldeb vem aumentando.

Feita tais constatações apresentamos, nas Figuras 12 e 13, os dados relativos à distorção idade-série no $9^{\circ}$ ano das duas escolas. A distorção idade-série é a proporção de alunos com mais de 2 anos de atraso escolar.

$100 \%$

$80 \%$

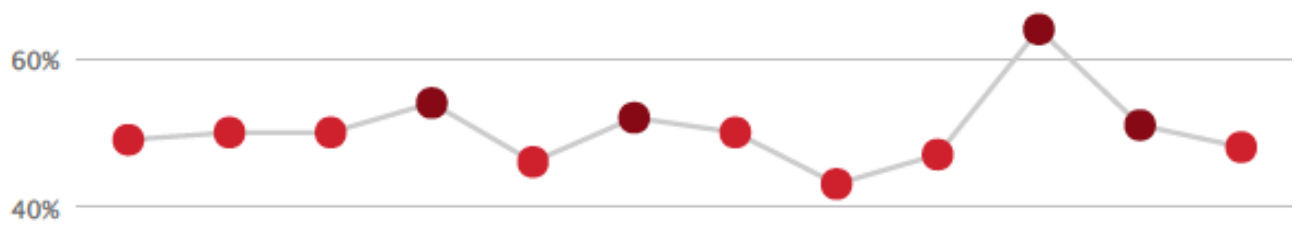

$20 \%$

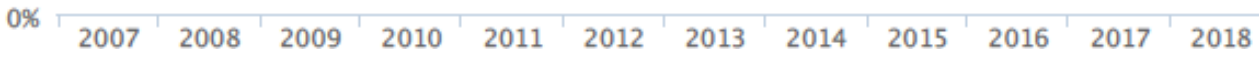

Figura 12 - Distorção idade-série escola Travessia/9aano - 2007-2018

Fonte: Fundação Lemann e Merrit (2020) 


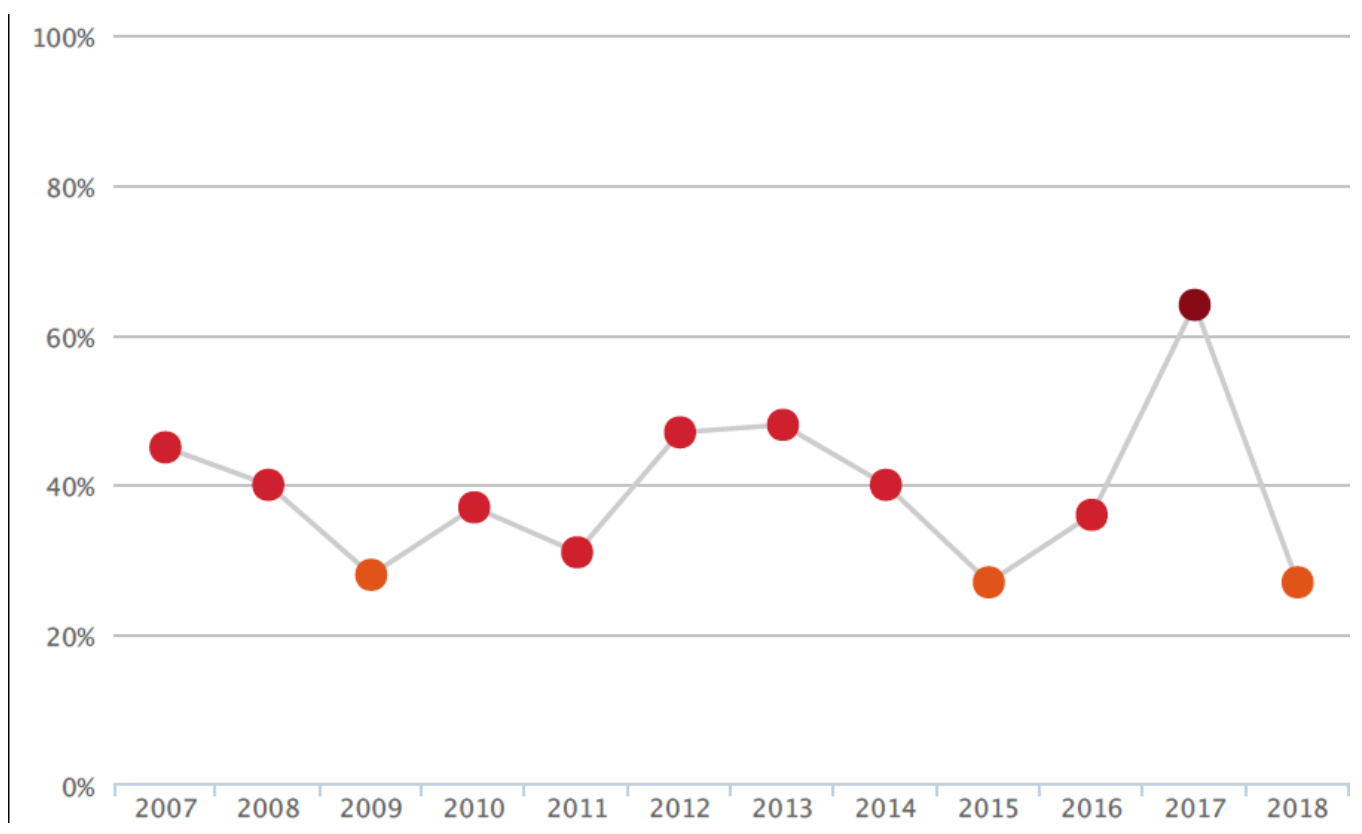

Figura 13 - Distorção idade-série escola Jardim Botânico/9ªno - 2007-2018 Fonte: Fundação Lemann e Merrit (2020)

Os dados apresentados nas Figuras 12 e 13 indicam que, ainda que em proporções diferentes, a distorção idade-série no $9^{\circ}$ ano, reflexo das reprovações em anos anteriores, é um problema em ambas as escolas. $\mathrm{Na}$ escola Travessia a distorção é mais preocupante haja vista que ela fica igual ou maior que $50 \%$ durante todo o período analisado. Já na escola Jardim Botânico, com exceção do ano de 2017, a distorção é inferior a 50\% na maior parte do período analisado.

Apresentamos também os dados da avaliação externa estadual (PROEB/Simave) para o 9ำ ano nas escolas. A trajetória da proficiência média em Língua Portuguesa e Matemática no $9^{\circ}$ ano nas duas escolas é semelhante. Ambas estão no mesmo padrão de desempenho ${ }^{15}$ (intermediário) desde 2014, tanto na disciplina de Língua Portuguesa quanto na de Matemática conforme podemos verificar nos Gráficos 5 e 6.

\footnotetext{
${ }^{15}$ A escala de proficiência do Simave possui quatro padrões de desempenho: baixo, intermediário, recomendado e avançado. Os padrões são os mesmos para língua portuguesa e matemática. $O$ que varia entre as escalas das disciplinas são os intervalos de cada padrão de desempenho.
} 


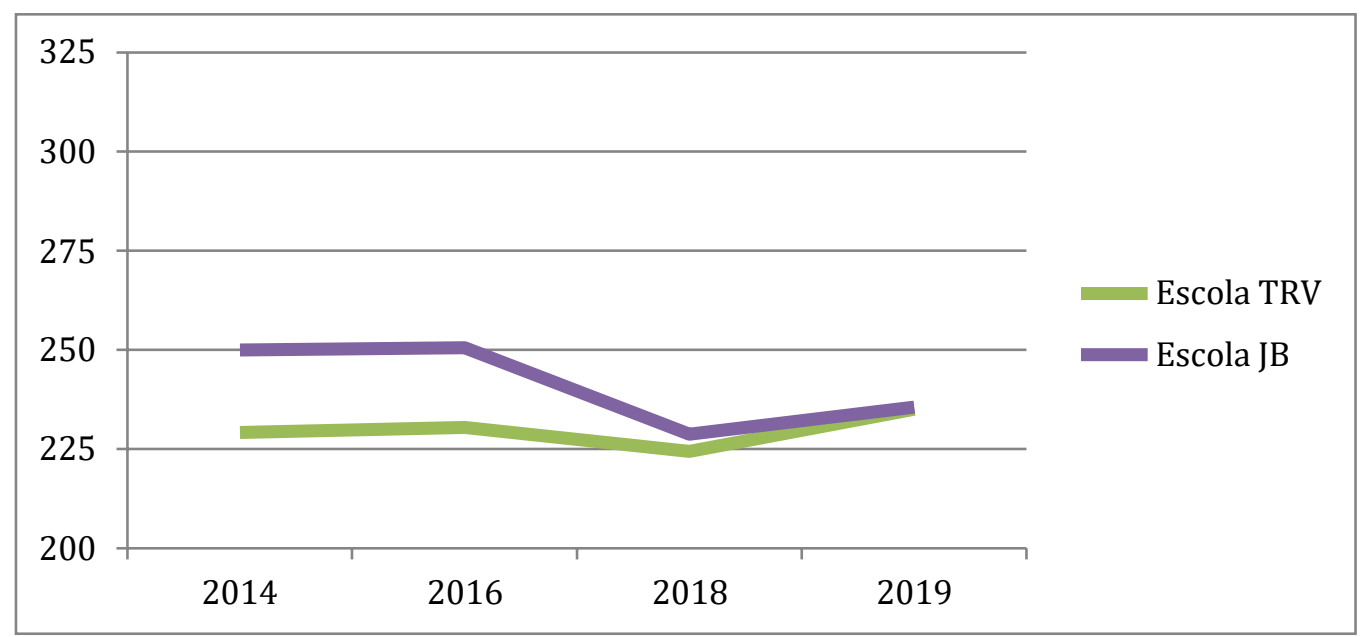

Gráfico 5 - Média desempenho PROEB/SIMAVE - 9aano - Língua Portuguesa Fonte: Elaborado pela autora a partir de dados do Simave (2019).

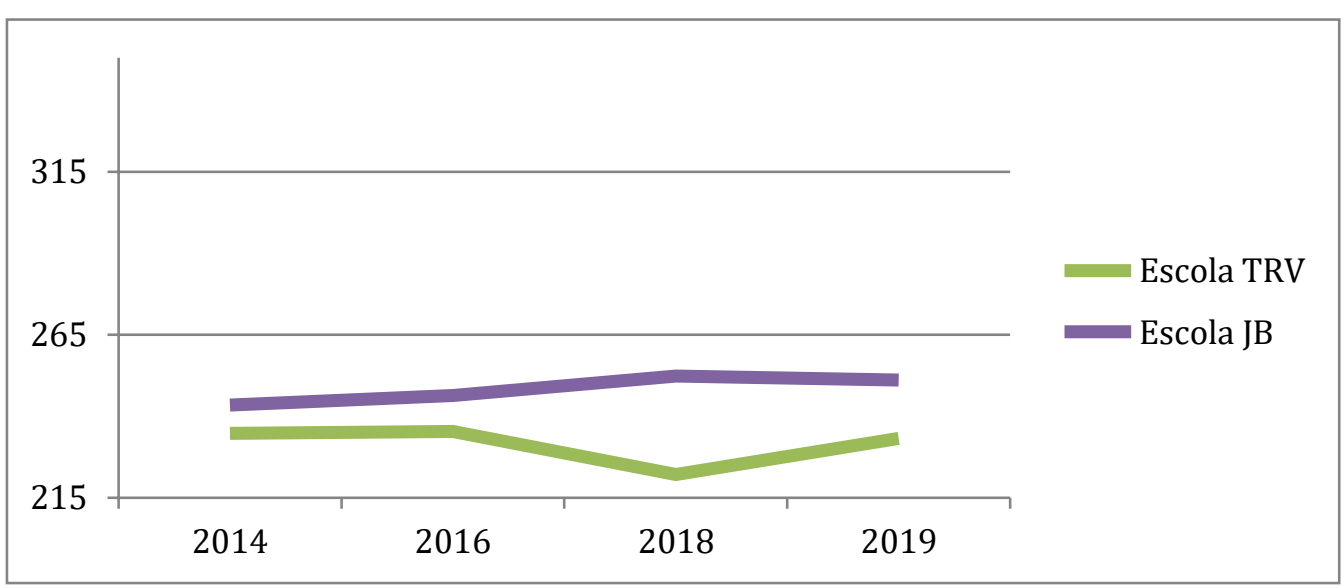

Gráfico 6 - Média desempenho PROEB - 9a ano - Matemática

Fonte: Elaborado pela autora a partir de dados do Simave (2019).

Ao analisar as porcentagens de alunos dentro de cada padrão de desempenho do PROEB no período de 2014-2019, temos uma média de $81 \%$ dos alunos do $9^{\circ}$ ano da escola Travessia e $73 \%$ da escola Jardim Botânico no padrão de desempenho baixo e intermediário em Língua Portuguesa. Já para Matemática essa média percentual de alunos sobre para $93 \%$ e $85 \%$, respectivamente.

A partir das informações apresentadas podemos afirmar que as duas escolas possuem o mesmo padrão de construção das escolas mineiras e a mesma constituição da equipe gestora (diretor, vice diretor, especialistas e ATBs), apesar das diferenças nos tipos de vínculos contratuais. Da mesma forma, possuem números de docentes bem próximos, mas inversamente diferentes quanto ao tipo de contrato, já que na escola Travessia mais da 
metade possui contrato temporário e na escola Jardim Botânico a maioria é efetivo. Sobre o desempenho das escolas nas avaliações externas podemos afirmar que, mesmo não estando nos padrões mais elevados das escalas de proficiência, a escola Jardim Botânico é relativamente melhor que a Travessia. Dito isto, na seção seguinte, teceremos considerações a respeito de alguns dos indicadores relacionados ao uso de dados, tais como: a importância de suporte técnico e de formação para uso dos dados e a infraestrutura para o acesso ao sistema de uso de dados.

\section{4}

\section{As escolas e os processos organizacionais para uso de dados}

Os estudos de Waymann et al. (2012), Farrell (2015), Roegman et al. (2017), Park (2018) e Roegman et al. (2019) afirmam que o uso de dados para a tomada de decisão é fortemente influenciado pela cultura e pelo contexto em que as escolas estão. Destacam o trabalho dos órgãos intermediários do sistema educacional, na medida em que são eles que dão sentido para os dados, ou seja, são os sujeitos que atuam nos órgãos intermediários que, inicialmente, interpretam os dados e dão sentido para os mesmos. E, ao fazer isso, quando eles chegam nas escolas podem mostram para os gestores e professores modos de se olhar e pensar os dados. Se recontextualizarmos isso para o sistema educacional estadual mineiro, temos que as SREs fariam esse papel inicial de interpretação dos dados e, depois, através do trabalho da inspeção escolar, os dados chegariam para as escolas e os inspetores auxiliariam no processo de reflexão e uso dos dados. Contudo, conforme mostramos na seção anterior há uma precarização do trabalho do inspetor escolar na SRE de Juiz de Fora na medida em que cada um deles tem que acompanhar uma média de 25 escolas e realizar visitas periódicas.

O estado de Minas Gerais, desde a década de 1990, investe nos sistemas de avaliação e de gestão administrativa (Simave e Simade) e em políticas públicas para fomentar o uso de dados. Sendo assim, as escolas públicas e os profissionais desta rede de ensino atuam em um contexto institucional em que há produção de dados e incentivo ao uso de dados por 
meio de políticas públicas. No ano de 2019 a SEE/MG tinha duas políticas públicas com foco no uso de dados para melhorar a aprendizagem dos estudantes: os Itinerários Avaliativos e o Jovem de Futuro, conforme apresentamos antes. Diante disso, iremos apresentar a seguir, a proposta do Dia do Currículo cujo objetivo era envolver a comunidade escolar na discussão sobre o PPP da escola (realizado por meio dos Itinerários Avaliativos) e sobre o Novo Ensino Médio (atrelado à política do Jovem de Futuro).

\subsection{1}

\section{O Dia do Currículo: orientações institucionais}

Anualmente, é previsto no calendário das escolas estaduais um sábado letivo chamado Virada da Educação. Neste dia, todas as escolas estaduais devem realizar uma mesma proposta de trabalho que é enviada pela SEE/MG. Em 2019, a proposta enviada pela SEE/MG para as escolas estava de acordo com a proposta do Ministério da Educação segundo a qual as escolas deveriam discutir a implementação dos novos currículos elaborados a partir da BNCC. Na rede estatual de Minas Gerais esse dia foi chamado de Dia do Currículo. De acordo com o documento orientador enviado para as escolas pela SEE/MG no Dia do Currículo a

[...] a rede estadual de educação de Minas Gerais se envolverá em discussões a respeito do Novo Ensino Médio e realizará o Itinerário 10 - Síntese do diagnóstico e definição de prioridades, fase essencial na revisão do PPP. (...) O Dia do Currículo será um dia descontraído em que a escola deverá realizar atividades para envolver a comunidade nas reflexões acerca do Novo Ensino Médio e no processo de revisão de seu PPP. (Minas Gerais, 2019, s.p.)

Para que as discussões tivessem a participação da comunidade escolar, as escolas deveriam planejar estratégias de mobilização e de divulgação nas semanas anteriores ao Dia do Currículo e, para tanto, elas poderiam construir cartazes, enviar convites para as famílias e fazer apresentações culturais, além de divulgar nas redes sociais da escola. (Minas Gerais, 2019).

No dia do evento as escolas deveriam recepcionar a comunidade com um café e depois dividi-las em, no mínimo, 8 grupos - 2 para temas ligados 
ao Novo Ensino Médio e 6 para temas ligados aos Itinerários Avaliativos. Cada grupo de discussão deveria contar com a presença de 1 professor mediador, 1 representante dos estudantes, estudantes e seus responsáveis e demais funcionários do quadro pedagógico e administrativo da escola. (Minas Gerais, 2019).

Nos grupos dos Itinerários Avaliativos, o professor mediador iniciaria as discussões apresentando dois pontos que precisariam de melhoria levantados ao longo da realização dos Itinerários 3 a 9 - mais prioritários para a escola. Por exemplo, no grupo do itinerário 5 - análise do desempenho, fluxo e frequência - o professor mediador deveria apresentar dois pontos prioritários elencados pela escola quando este itinerário foi realizado para serem discutidos no grupo. Dessa forma, a escola estaria realizando o Itinerário 10 - Síntese do diagnóstico e definição de prioridades junto à comunidade. Minas Gerais, 2019).

Já nos grupos de discussão do Novo Ensino Médio o professor mediador deveria apresentar a análise do questionário de Escuta para um Novo Ensino Médio ${ }^{16}$, que deveria ter sido aplicado previamente para os estudantes do Ensino Médio, e depois discutir quais as possíveis formações para a educação profissional e técnica. (Minas Gerais, 2019).

Findada as discussões, todos deveriam se reunir para uma plenária na qual haveria o compartilhamento de todas as discussões realizadas separadamente nos grupos e as propostas poderiam ser apresentadas. De acordo com as orientações da SEE/MG

\begin{abstract}
Ao apresentar cada ponto de melhoria priorizado dos Itinerários Avaliativos, peça que a comunidade presente aponte rapidamente algumas sugestões de ações de melhoria. Ainda não é o momento de se fazer juízo de valor ou se aprofundar sobre as atividades de cada ação. O objetivo desse momento é mostrar para a comunidade que sempre é possível pensar em ações para melhorar a realidade escolar, além de permitir o engajamento dos atores presentes. Portanto, é importante que se agradeça a todas as sugestões e se tome nota delas. (Minas Gerais, 2019).
\end{abstract}

Após a realização do Dia do Currículo, as escolas deveriam preencher o Formulário de Registro das Atividades e enviá-lo para a SEE/MG. Nesse formulário havia campos para registro dos resultados da Etapa de Revisão

${ }^{16}$ Esse questionário foi enviado pela SEE/MG para todas as escolas. 
dos Itinerários Avaliativos, com a possibilidade de inclusão de fotos e outras informações que a escola julgasse necessárias (Minas Gerais, 2019). Na próxima etapa dos Itinerários Avaliativos esses pontos deveriam ser utilizados na definição das ações de melhoria, ou seja, no Plano de Ação da escola, etapa final dos Itinerários Avaliativos. (Minas Gerais, 2019).

\subsection{2}

\section{A execução do Dia do Currículo}

O Dia do Currículo aconteceu no dia 21 de setembro de 2019 para todas as escolas da rede estadual e, por conta disso, optamos por ficar na escola Travessia, pois já estávamos fazendo a pesquisa nesta escola desde agosto/2019 e tínhamos maior familiaridade com o contexto e com os atores escolares. Na escola Jardim Botânico estávamos iniciando o campo.

Iniciaremos esta seção com o relato do que aconteceu neste dia na escola Travessia para, depois, tecermos considerações sobre o que foi feito e o que deveria ter sido feito de acordo com as orientações da SEE/MG.

A equipe gestora da escola Travessia elaborou o seguinte cronograma para o Dia do Currículo:

- 7:30 às 8:30 - café coletivo;

- $\quad$ 8:30 às 9:30 - abertura da reunião e vídeo Instituto Unibanco;

- 9:30 às 10:30 - grupos de discussão: Itinerários Novo Ensino Médio - Jovem de Futuro;

- $\quad$ 10:30 às 11:30 - plenária;

- $\quad 11: 30$ às $12 \mathrm{~h}$ - encerramento.

No Dia do Currículo estavam presentes, além da equipe gestora, a inspetora escolar, todos os professores da escola, alguns alunos e pais/responsáveis. A diretora iniciou a reunião com a apresentação do power point, elaborado pelo Instituto Unibanco, sobre a política do Jovem de Futuro, seus objetivos e os resultados de desempenho e indicadores de rendimento da escola para explicar que a mesma estava na categoria "prioritária" do programa já que o Ideb do Ensino Médio estava aquém do 
esperado (2.7 em 2019). Feito isso, passou um vídeo do superintendente executivo do Instituto Unibanco e, em seguida, convidou todos para o café coletivo.

Depois do café a diretora entregou os formulários de discussão para os grupos de professores referentes à etapa 3 dos Itinerários Avaliativos, composto pelos itinerários de 3 a 8 . Segundo ela a escolha dos professores para compor cada grupo de discussão foi feita de acordo com o perfil de cada professor.

É, aí a gente já tem mais ou menos o perfil de cada professor para aquilo ali. A gente, por exemplo, o itinerário que tinha que medir, que tinha que falar sobre gráfico de produtividade, de resultado de avaliações, eu deixei com o pessoal da área de exatas para mexer com gráfico, essas coisas. 0 itinerário que tinha que falar mais sobre a comunidade, mais a nível de relações, eu deixei com o pessoal da humanas. E os professores de anos iniciais eu também fui encaixando. Tinha um itinerário específico para educação especial. Foi segundo o perfil do professor que a gente foi colocando. (Diretora Travessia. Grifo nosso).

Como revela a fala da diretora, o critério para formar os grupos de discussão dos itinerários foi relacionado às disciplinas que os professores lecionavam, ou seja, se tinha gráficos, pessoal da área de exatas, se envolvia discussão sobre comunidade, pessoal de humanas. Não houve uma reflexão sobre o significado das informações presentes nos itinerários para definir quem deveria estar em cada itinerário e em que medida a qualidade das discussões poderiam reverberar em ações na escola. A nossa expectativa era que, primeiro, tivesse sido apresentada a programação do evento para todos os presentes. Depois que a diretora tivesse explicado, das ações que seriam desenvolvidas naquele dia, quais diziam respeito à terceira etapa dos Itinerários e quais atividades eram relativas ao Jovem de Futuro e quem estaria em cada uma delas. Especificamente sobre a escolha dos professores que comporiam os grupos de discussão dos Itinerários tínhamos como expectativa que a diretora misturasse professores de diferentes áreas.

Definidos os grupos, os professores encaminharam-se para as salas de aula onde deveriam realizar as discussões relativas aos itinerários entregues. Os poucos alunos presentes foram encaminhados pela direção da escola para alguns grupos e os pais foram embora depois do café. 
No dia acompanhamos os grupos dos Itinerários 5 (direito à aprendizagem) e 7 (impacto da violência nas expectativas de aprendizagem). A escolha por estes grupos se deu em função das temáticas que seriam discutidas, uma vez que elas se relacionavam às discussões sobre uso de dados e clima escolar e, por isso, descreveremos o que aconteceu nestes grupos.

A princípio os professores não sabiam o que era para ser feito e ficaram perguntando uns aos outros o que cada um tinha entendido da fala da diretora. Interpretamos que isso foi reflexo das ações da diretora, que apresentou o Jovem de Futuro e, na sequência, entregou um formulário de discussão que dizia respeito à política dos Itinerários Avaliativos. A falta de explicação sobre a programação e o que deveria ser feito causou dúvidas entre os professores. Inclusive, observamos nos grupos dos itinerários 5 e 7 que o momento inicial de organização dos grupos e a definição do que deveria ser feito foi confuso, já que foi necessário construir um consenso entre os participantes para definir o processo de execução do formulário do itinerário entregue.

Os formulários do Itinerário 5 - análise do desempenho e rendimento dos estudantes - e do Itinerário 7 - impacto da violência nas expectativas de aprendizagem - eram compostos por blocos de perguntas abertas e fechadas que deveriam ser discutidas em conjunto nos grupos. Contudo, em alguns casos os professores precisariam ter acesso a alguns dados da escola e, como eles não foram informados, a priori, que eles estariam nestes Itinerários, não foi possível acessar e nem levar nenhum tipo de dado para ser discutido. Por exemplo, no formulário do itinerário 7 havia uma pergunta fechada sobre qual era o percentual aproximado que os Registros de Situações de Violência representavam em relação a todas as situações de violência que ocorreram na escola. E os professores não tinham como responder a essa questão, pois não tinham os dados relativos aos registros. No itinerário 5 essa ausência de preparação das informações para as discussões foi ainda pior, na medida em que era preciso discutir dados sobre o desempenho dos alunos. Por exemplo, tinha no formulário a seguinte questão: Considerando a evolução da proficiência/desempenho dos estudantes da escola, por etapa de ensino e componente curricular, 
nas últimas quatro edições das avaliações externas do SIMAVE (PROEB e/ou PROALFA): faça uma análise descritiva (a proficiência aumentou, diminuiu ou se manteve ao longo dos anos?); indique quais as possíveis causas para essa variação ou manutenção da proficiência; quais ações foram implementadas para a melhoria da proficiência/desempenho dos alunos?

Por conta disso, após as discussões sobre as ações futuras para solucionar os problemas identificados eram genéricas e versaram sobre: utilizar os sábados letivos para conscientizar a comunidade escolar sobre a importância da frequência dos alunos na escola; sobre a participação das famílias; maior diálogo na sala de aula, sem que o professor perca sua autoridade; e palestras com relatos pessoais de ex-alunos da escola sobre a importância da formação para a vida profissional.

Findada a discussão, todos os grupos se reuniram para uma plenária na qual foram apresentados os problemas identificados em cada itinerário e os possíveis caminhos para resolvê-los.

Tudo isso que apresentamos até aqui, é o nosso relato sobre o que aconteceu no Dia do Currículo. Agora, analisaremos o que foi feito depois que realizamos uma pesquisa documental para entender a proposta do Dia do Currículo já que, na época da pesquisa de campo, isso ainda não havia sido feito.

Desde o início é possível perceber que a equipe gestora executou a proposta do Dia do Currículo de maneira distinta daquela enviada pela SEE/MG, visto que iniciaram a reunião apresentando a proposta do Jovem de Futuro. Algo que não constava nas orientações institucionais da SEE/MG conforme relatamos na seção anterior.

Além disso, a proposta de discussão dos itinerários avaliativos da etapa 3 - diagnóstico - foi totalmente distorcida. A proposta da SEE/MG era que as escolas discutissem com a comunidade dois problemas elencados como prioritários dentro de cada itinerário da etapa 3. Para isso, portanto, as escolas deveriam ter realizado cada um dos itinerários de acordo com o cronograma da SEE/MG. O que aconteceu na escola Travessia foi que nenhum dos itinerários da etapa 3 haviam sido realizados e a equipe gestora resolveu fazer tudo no Dia do Currículo. Isso explica, 
por exemplo, o porquê de os professores terem ficado confusos e não terem como acessar os dados da escola, conforme necessário. Na verdade, a proposta de discussão com os formulários apresentada pela diretora para os grupos deveria ter sido feita em outras datas e separadamente, ou seja, cada um dos itinerários deveria ter sido pensado em um dia específico e não tudo ao mesmo tempo, conforme foi feito na escola.

Outro ponto que trouxemos para a análise diz respeito ao uso pela equipe gestora das informações dos itinerários feitos no Dia do Currículo.

\footnotetext{
Esse (Itinerário) aqui olha, eu tenho que colocar nele o dia que foi feita a reunião, o quantitativo de participantes, quem que participou, se teve professor, estudante, ATB, quem conduziu. (Diretora da escola Travessia).
}

Vem assim: itinerário número 1, aí vem pedindo alguma coisa. Aí, principalmente a direção e a supervisão é que responde esses itinerários e vai inserir na plataforma dos itinerários avaliativos. Já tá no nono. Algumas eu levei nas reuniões de módulos, porque alguns deles pedia a participação do coletivo. [...] Aí depois que ele era respondido é que a gente insere na plataforma que tem os itinerários. (Diretora da escola Travessia).

Os itinerários é aquilo que eu te falei. É colocar na plataforma de forma revisando os que a gente já fez. E a parte que vem falando do novo currículo, né, durante o ensino médio, agora é também colocar na plataforma as ações que a escola agora vai pegar como meta pra tentar melhorar a aprendizagem. (Diretora escola da Travessia).

[...] a gente é insere os resultados nas plataformas, depois a gente recebe esses resultados em forma de gráfico, em forma de barras, em forma do que for numa tentativa de você fazer daquilo e identificar o que você está errando. (Vice diretor da escola Travessia).

Os relatos da equipe gestora sobre o tipo de encaminhamento que eles dão para os dados coletados nos Itinerários nos permitem afirmar que eles são, majoritariamente, protocolares ou administrativos, ou seja, eles coletam as informações e preenchem a plataforma do programa. Durante todo o tempo de observação na escola não vimos a equipe gestora planejar as ações e, tampouco, colocá-las em prática.

$\mathrm{Na}$ época da realização da pesquisa de campo nesta escola ainda não tínhamos a dimensão sobre o que, de fato, era a proposta da SEE/MG para o dia do Currículo, visto que as orientações foram enviadas para as escolas e não estavam publicizadas. Sendo assim, depois do Dia do Currículo conversamos com a diretora na tentativa de esclarecer se a escola havia 
recebido algum tipo de orientação para o Dia do Currículo, a diretora respondeu que:

\begin{abstract}
Tem toda uma orientação. Geralmente, a Virada da Educação sempre foi o dia em que a escola se envolve mais a nível de apresentações culturais, sempre foi assim. Esse ano é que ela veio trabalhando o dia do Currículo especificamente. Então, vieram umas orientações. Dentro daquelas orientações, teve até algumas sugestões de dinâmicas que fossem trabalhadas dentro do tema único, que era o dia do currículo e os itinerários avaliativos. Então, era pra trabalhar os oito itinerários que já foram realmente feitos por nós, principalmente por mim, pela supervisora. $E$ aí, agora a gente tá refazendo esses itinerários. Então, eles trouxeram que a ideia de que a escola dividiria os professores em grupos, cada grupo iria trabalhar um itinerário, e um grupo ficaria por conta do programa dos Jovens de Futuro. Então, você deve ter visto sábado que cada um ficou com um gestor na biblioteca, que era um grupo específico do Jovem de Futuro. Os outros grupos trabalharam os itinerários, que na hora da plenária serviu, que foi exposto lá. (Diretora escola da Travessia).
\end{abstract}

Diante da fala da diretora, podemos afirmar que apesar de a escola ter recebido as orientações para o dia do Currículo, elas foram interpretadas e maneira diferente pela diretora.

Nesta seção descrevemos e analisamos uma prática, na escola Travessia, que tinha como pano de fundo para sua execução o uso de dados e, a partir disso, verificamos que o modo como a escola a colocou em prática foi avessa à proposta da SEE/MG. Nesse sentido, podemos afirmar que o caráter discricionário da equipe gestora para executar a proposta do Dia do Currículo foi significativa. Essa constatação se torna ainda mais relevante na medida em que naquele dia a inspetora da escola estava presente e em nenhum momento interveio naquilo que estava sendo feito nem, tampouco, buscou conversar sobre o ocorrido com a equipe gestora depois. Ora, era de se esperar que ela, enquanto mediadora da relação entre escola e SRE tivesse refletido com a escola o que eles fizeram, já que não condizia com a proposta da SEE/MG.

A seguir falaremos sobre a importância da formação para que o uso dos dados se torne uma prática na escola.

\title{
3.4 .3
}

\section{A formação para o uso dos dados}

Waymann et al. (2012), Supovitz et al. (2012) e Farrell (2015) afirmam que para um uso pedagógico dos dados é necessário que os agentes 
escolares tenham familiaridade e se sintam confortáveis para falar sobre dados. Contudo, para que isso aconteça é necessário que haja formação sobre os dados, ou seja, é necessário um data literacy ${ }^{17}$ (Lasater et al., 2019). Durante a pesquisa de campo não observamos nenhum processo de formação da SRE/JF com a equipe gestora e nem desta com os professores relativos à compreensão e ao uso de dados. Concluímos que, pelo menos no caso desta escola, essa familiaridade e prática com os dados não acontece. A seguir apresentamos um trecho de fala da diretora a respeito das avaliações do Simave no momento em que conversávamos sobre os diferentes perfis de escolas estaduais da Juiz de Fora.

[...] são escolas que têm como objetivo principal focar na universidade. Então os resultados do Simave são preparados para aquilo ali, entendeu? Isso é uma coisa que a gente sempre fala que não é muito justo a prova ser igual, sabe? Eu acho que o governo tem que ter os avaliadores dele, claro, para ter o acompanhamento, mas ele não pode estabelecer critérios únicos para escolas com clientelas distintas. (Diretora escola da Travessia).

A fala da diretora da escola Travessia vai de encontro aos princípios da avaliação externa que busca, por meio de uma prova única, gerar um diagnóstico sobre a aprendizagem dos alunos na idade certa e, para tanto, possui uma matriz de referência e uma escala de proficiência. Pelo que foi dito, a diretora parece desconhecer essas premissas da avaliação externa o que pode, então, gerar desconfiança em relação aos dados provenientes desses exames. Diante disso, um processo de formação sobre os dados seria muito importante para descortinar tais questões e fazer com que a diretora compreendesse a relevância dos testes estandardizados para a oferta de uma educação pública de qualidade e a garantia do direito de aprender do estudante.

A SEE/MG gerencia uma grande rede de escolas e faz isso por um processo de descentralização via SREs, que se estruturam em diretorias responsáveis por três linhas de trabalho: administrativa e financeira, pessoal e educacional. A diretoria educacional, especificamente, é a responsável por oferecer suporte pedagógico para as escolas e, por isso,

\footnotetext{
17 Esse termo é utilizado na área educacional para denominar o conjunto de habilidades, conhecimento e disposição em que os professores precisam estar capacitados para utilizar os dados de forma eficaz e com maturidade (Mandinach \& Gummer, 2016 apud Nuñez et al, 2019).
} 
possui setores específicos que dividem as demandas relativas ao suporte tecnológico, ao acesso ao Simade; e ao monitoramento e formação dos servidores. Sendo assim, é uma rede educacional que está organizada para oferecer suporte tecnológico e de acesso aos sistemas de gestão e que investe em políticas públicas para uso de dados nas quais o gestor escolar atua como sujeito chave.

Porém, de acordo com as pesquisas de Freitas (2017) e Protes (2020) os processos de formação para uso de dados oferecidos pela SEE/MG, via programas e projetos, não aconteceram no âmbito escolar conforme previsto. Ou seja, apesar de haver a previsão de formação para uso dos dados, a execução da mesma parece não ter ocorrido conforme previsto. Pode-se concluir, então, que as escolas pertencentes à SEE/MG têm acesso a uma rede de apoio e suporte para uso de dados, mas que a formação e o monitoramento deste uso não se efetiva na prática.

Os dados empíricos apresentados até aqui permitiram conhecer o contexto macro e micro organizacional em que as escolas estão e verificar as semelhanças e diferenças entre elas, suas equipes e seus diretores. Especificamente sobre estes últimos, observamos diferentes estilos de gestão (Paes de Carvalho \& Canedo, 2011) que acabam por impactar o processo de uso de dados para fins pedagógicos na escola. No próximo capítulo buscaremos caracterizar o diretor escolar dentro da lógica de funcionamento da burocracia moderna e refletir sobre as racionalidades burocráticas observadas em cada contexto escolar. 


\section{4}

\section{Racionalidade burocrática e Gestão Escolar}

A habilidade para analisar dados educacionais e transformá-los em informações, conforme vimos no ciclo de Marsh (2012), é crucial para a tomada de decisão com base em evidências que tem como objetivo último melhorar a aprendizagem dos estudantes através de práticas pedagógicas. Apesar disso, conforme pudemos constatar na pesquisa nas escolas, uma série de barreiras se impõem para que este processo culmine em práticas pedagógicas voltadas para a garantida do direito à aprendizagem dos estudantes.

Neste capítulo apresentamos o referencial teórico que guiou nosso olhar analítico sobre o quinto fator mapeado, a racionalidade burocrática dos gestores, e a sua influência os processos de ressignificação dos dados na sua rotina de trabalho conforme Figura 14.

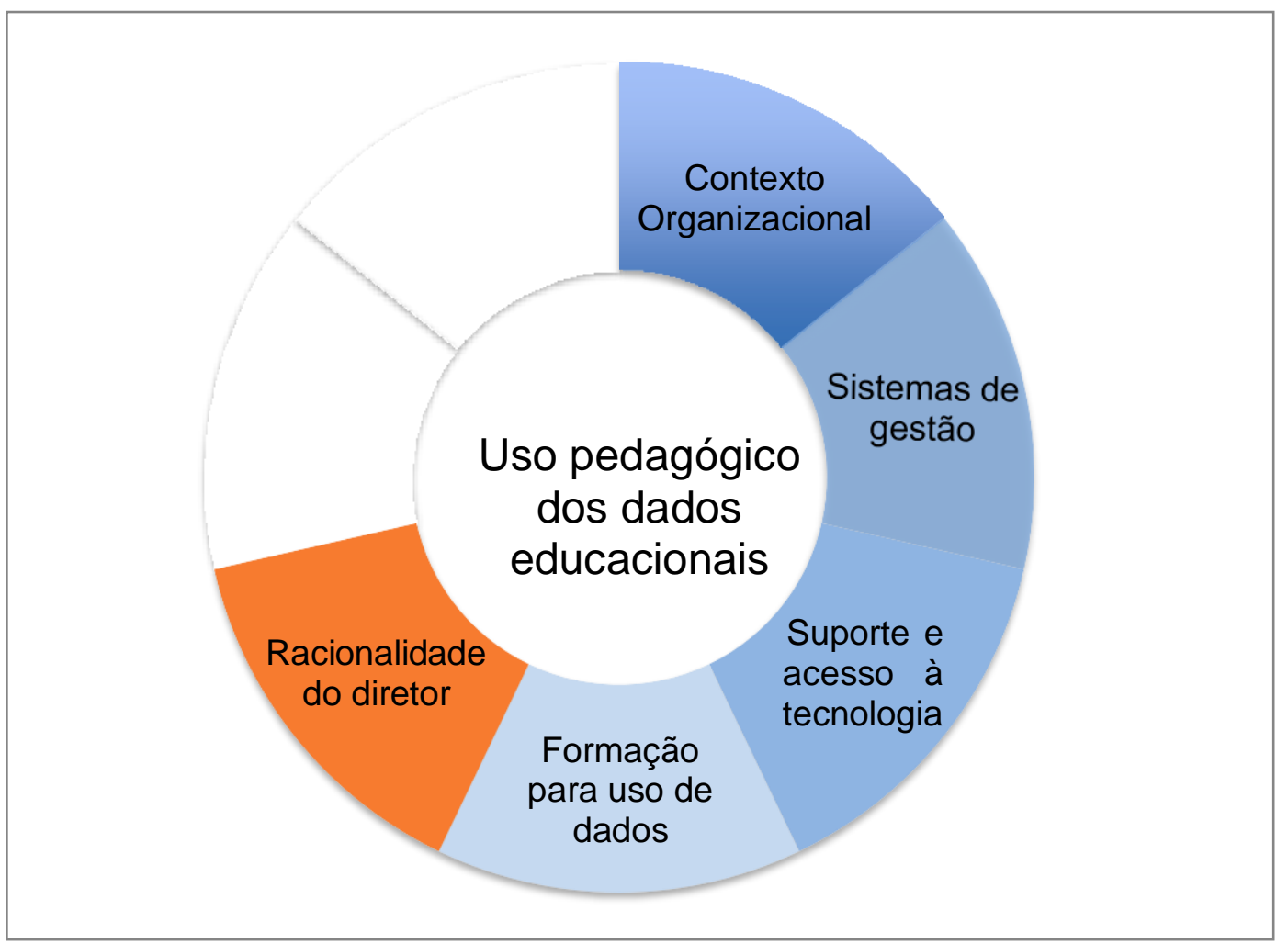

Figura 14 - Fatores que influenciam no processo de uso pedagógico dos dados educacionais

Fonte: Elaborado pela autora (2020). 
Para tanto, foi necessário compreender quem são os gestores escolares dentro da lógica de funcionamento do estado e como eles agem por meio do processo de racionalização burocrática. Para a discussão sobre racionalidade nos pautamos na leitura de Vandenbergh (2012) sobre a obra de Weber e, dessa forma, trazemos para a arena de discussão a racionalidade do diretor como interveniente na prática de uso de dados.

\section{1 \\ Racionalidade, burocracia e o gestor escolar}

[...] a racionalidade é um conceito histórico que recobre um mundo de oposições. [...] A vida pode ser racionalizada conforme pontos de vista extremamente diversos e segundo direções extremamente diferentes. [...] Para falar a verdade, seria preciso colocar como epígrafe de todo estudo sobre a racionalidade este princípio bastante simples, mas frequentemente esquecido. (Weber, 1960 apud Vandenbergue, 2012, p. 81-82).

Para compreender o processo de racionalização burocrática que envolve as ações dos gestores escolares frente aos dados que são disponibilizados nos sistemas de gestão e avaliação da rede estadual de educação de Minas Gerais é de fundamental importância situarmos o que estamos denominando de racionalização burocrática. De acordo com Vandenberghe (2012), a tradição sociológica weberiana foi fundamental para entender o funcionamento do Estado Moderno e a consolidação do processo de racionalização que se organizou, predominantemente e de forma eficiente, pela burocracia.

A racionalização teórica das imagens do mundo ocidental moderno é considerada por Weber um processo de "desencantamento do mundo", uma vez que os fenômenos do mundo deixam de ser explicados com base em fontes religiosas e nas tradições sociais transmitidas, mas com argumentos que guardam coerência lógica lastreados em fatos observados ou experimentados pelos sujeitos, bem como o conhecimentos sobre os meios empregados para aferi-los, conduzindo assim a explicações ou consequências unívocas ou racionais (Vandenberghe, 2012).

Vandenberghe (2012) ao analisar o uso do adjetivo "racional" na obra Ética protestante e o "espírito" do capitalismo, de Max Weber, realiza uma decomposição analítica das diferentes significações que o conceito de racionalidade assume nesta obra, distinguindo principalmente entre dois 
tipos de racionalidade: i) a subjetiva e ii) a objetivada. A racionalidade subjetiva é aquela ligada aos processos mentais de subjetivação dos sujeitos, ou seja, está relacionada ao pensamento individual e, por isso, está intrinsecamente permeada de valores e ideologias. Para Vandenberghe (2012), Weber analisa a racionalidade subjetiva em dois contextos diferentes: o da compreensão racional e o da ação racional.

De acordo com Vandenberghe (2012, p. 262) a compreensão racional "implica a compreensão intelectual, não-emocional da coerência dos elementos da ação na situação de ação". Nesse sentido, ela é mais precisa quando o tipo de lógica aplicada na racionalidade é a formal ou a econômica. A compreensão pelo sujeito é única quando a lógica do raciocínio aplicada ao pensamento é formal, por exemplo quando se utiliza a proposição $2 \times 2$ = 4 ou quando a partir de fatos de experiência que nos parecem conhecidos e identificados os meios empregados, que resultam consequências unívocas.

No segundo contexto, da ação racional, Weber distingue quatro tipos ideais de ação social: i) ação racional orientada a um fim, ii) ação racional orientada a um valor; iii) ação ou comportamento tradicional e iv) ação ou comportamento afetivo. A diferença entre os dois primeiros e os demais reside no fato de que a ação racional orientada "não opera nem pela expressão dos afetos (nem, sobretudo, emocionalmente), nem pela tradição" (Vandenberghe, 2012, p. 264). Por isso, os dois primeiros são processos racionais enquanto os dois últimos não são.

No que toca à racionalidade empregada na ação racional orientada a um fim, os seus fins são ditados por interesses nos resultados ou consequências da ação. Por outro lado, na ação racional orientada a um valor, o indivíduo não se preocupa com as consequências previsíveis de seus atos, já que o que move o seu agir são os valores em que ele acredita (Vandenberghe, 2012).

Transpondo tais compreensões sobre a racionalidade subjetiva para o nosso campo de pesquisa, poderíamos afirmar que o gestor escolar constrói a sua racionalidade por meio das suas subjetividades (valores e ideologias) as quais influenciam seu modo de compreender e de agir na escola. No âmbito das atividades sociais na escola o gestor age mesclando 
elementos desses quatro tipos de ações racionais dependendo das situações nas quais ele precisará agir e decidir. Nesta pesquisa, almejamos compreender a práxis dos gestores escolares frente aos dados disponibilizados pelos sistemas de gestão e de avaliação da rede estadual de Educação de Minas Gerais. Por conta disso, nos interessa compreender como os dados ${ }^{18}$ são ou não utilizados na prática de gestão da escola e como os gestores pensam sobre os dados. Nesse sentido, seus processos de racionalização sobre os dados envolvem o que eles pensam sobre os dados (ação racional orientada a um valor) e como eles atuam e tomam decisões a partir do uso ou não dos dados (ação racional orientada a um fim ou a um valor).

No caso das ações dos gestores que usam os dados, pode-se considerar que os gestores identificam aspectos pertinentes da situação que são expostas pelos dados. Nessa situação, os gestores consideram que o desempenho medido pela avaliação corresponde ao que o aluno aprendeu, uma vez que foi verificado através de ferramentas cientificamente consistentes. A partir da concordância com essa premissa os gestores podem tomar decisões a respeito.

Além disso, a ação do gestor escolar estaria sempre articulando o valor (percepção sobre o aluno, expectativas, sentido da escola e da escolarização, utilidade do conhecimento escolar para aquele aluno, etc.) com a orientação para o atingimento de um fim (melhoria do aprendizado ou manter o aluno mais tempo na escola, por exemplo).

Por outro lado, a prática de não uso dos dados pode também se relacionar à ação orientada por um valor, pois, hipoteticamente, o gestor pode não fazer uso dos dados (campo da ação) ou porque acredita que o sistema de onde o dado é proveniente fere os seus valores em sentido moral e ético por ser proveniente de instituições ligadas ao capital e a práticas de controle de um Estado-avaliador ${ }^{19}$, ou por não acreditar, num sentido próprio de crença, na fidedignidade da medida da avaliação externa

\footnotetext{
${ }^{18}$ Qualquer informação bruta a que os educadores tenham acesso sobre os estudantes (WAYMAN et al., 2012).

${ }^{19}$ Expressão cujo significado se relaciona ao fato de "[...] o Estado passar a admitir a lógica do mercado, através da importação para o domínio público de modelos de gestão privada, com ênfase no resultado e nos produtos dos sistemas educativos." (AFONSO, 2009, p. 49).
} 
e, assim, não reconhecer ${ }^{20}$ a escola nos dados. Diante disso, não haveria uma ação para o uso dos dados.

Outra importante dimensão referente ao uso dos dados é aquela relativa à lógica do interesse, ou seja, se o gestor tem interesse ou não no uso dos dados. Tal aspecto estaria relacionado a uma ação racional valorativa, já que o interesse poderia se dar, a princípio, por duas vias: a de cunho individual e a de cunho coletivo. No primeiro caso, o interesse seria puramente individual para ser considerado, por exemplo, como o "melhor" gestor (ganho de status), usando os dados para sustentar esse discurso fortalecendo-o com evidências publicamente reconhecidas como válidas ou legítimas. Um forte gatilho para esse tipo de interesse se relaciona, por exemplo, com algumas políticas de bonificação por resultados que tem como proposta premiar a escola, os alunos, os professores e a equipe gestora como reconhecimento do trabalho a partir dos resultados e incentivo para continuarem melhorando os resultados da escola nas avaliações externas.

No segundo caso, o interesse seria uma consequência das políticas da rede para fomentar o uso de dados para a melhoria aprendizagem que, como parte de uma ação externa de responsáveis hierarquicamente superiores se apresentaria 'a priori' como uma prática legítima. Sobre este aspecto, vimos na revisão bibliográfica, que em contextos que incentivam, via políticas públicas, o uso de dados, a prática tende a ser mais executada. Sendo assim, temos como hipótese que a racionalidade do contexto institucional (racionalidade objetivada) é uma variável relevante para a compreensão do uso dos dados e indicadores educacionais pelas equipes gestoras das escolas.

Da mesma forma que a racionalidade subjetiva, a racionalidade objetivada se apresenta de maneira diversificada nas diferentes esferas da vida. Porém, situa-se no campo de ação racional das instituições. De acordo com Vandenberghe (2012, p. 260) "enquanto a racionalidade subjetiva designa uma qualidade dos processos mentais subjetivos, a racionalidade objetivada é uma qualidade das instituições [...] é uma

\footnotetext{
${ }^{20}$ Caso os dados reflitam uma realidade diferente da que o gestor está habituado nas práticas cotidianas da escola, ele tende a duvidar dos dados cuja fonte são os sistemas.
} 
característica da 'cultura objetiva'”. O referido autor distingue, com base na obra de Weber, quatro tipos de racionalidade objetivada: i) teórica, ii) instrumental, iii) material e iv) formal. Tais noções de racionalidade podem ser assim entendidas:

i) um domínio teórico crescente da realidade por conceitos abstratos que são cada vez mais precisos (racionalismo intelectual) [...] ii) a realização de um objetivo prático dado pelo cálculo cada vez mais preciso dos meios adequados (racionalidade instrumental) [...] iii) racional no sentido do crescimento em um cânone válido (racionalidade material) e iv) racionalidade formal que seria organizada segundo um plano. (Vandenberghe, 2012, p. 266).

Em função do recorte da presente pesquisa buscar compreender o modus operanti dos gestores escolares dentro do sistema institucional de políticas públicas da Secretaria Estadual de Educação de Minas Gerais, iremos nos ater às racionalidades instrumental e formal.

A racionalidade instrumental é "relativa à manipulação, ao controle e ao domínio consciente e prático do meio ambiente com vistas a atingir objetivos e a satisfazer necessidades puramente pragmáticas." (Vandenberghe, 2012, p. 266). Consiste, assim, na maximização dos meios eficazes para obter o fim escolhido. Já a racionalidade formal, enquanto "uma propriedade objetiva das estruturas sociais da sociedade moderna." (Vandenberghe, 2012, p. 267), tem como características a impessoalidade, a objetividade, a disciplina e a indiferença ética. É denominada formal na medida em que a formalização é relativa à "organização sistemática dos meios e não dos fins materiais..." (Vandenberghe, 2012, p. 267).

Com base nessas reflexões, poderíamos afirmar que por um lado a racionalidade institucional da SEE/MG opera, na teoria, pela via instrumental na medida em que busca a máxima eficiência e, para isso, investe tanto em sistemas de gestão quanto em políticas públicas educacionais para maximizar a eficiência do processo educativo e minimizar custos. Por outro, tais sistemas funcionam dentro de uma lógica de sequências fixas de procedimentos (racionalidade formal) e, por isso, podem acabar gerando práticas burocráticas. Por exemplo, o preenchimento de informações em um sistema de gestão pode se dar muito mais por uma obrigatoriedade institucional do que, de fato, por um 
entendimento de que as informações ali inseridas podem informar ou orientar tomadas de decisão dentro da rede e da escola. Da mesma forma, as práticas de uso dos dados provenientes dos sistemas de avaliação externa podem, muitas vezes, ser caracterizadas e percebidas pelos gestores apenas como obrigações ou ações burocráticas, vez que há uma racionalidade formal neste processo desde a instância de gestão superior da rede até o plano da escola. Isso pode, portanto, favorecer uma percepção e atitude dos servidores em relação aos sistemas de gestão e de avaliação como parte de suas funções burocráticas sem relação com as possibilidades ou demandas de tomadas de decisão por parte da equipe gestora.

Vandenberghe (2012) afirma que a burocratização seria a via pela qual a racionalidade formal opera e, dessa forma, conformaria os modos de agir dos indivíduos. Este diagnóstico culminaria naquilo que Weber chama de "jaula de aço" (Vandenberghe, 2012), ou seja, o indivíduo estaria prisioneiro de uma lógica impessoal de funcionamento de um sistema que diz respeito às ações racionais no âmbito impessoal, enquanto burocratas do Estado (Vandenberghe, 2012).

Por outro lado, Giddens (2017, p.133) argumenta que essa perspectiva "é basicamente parcial e que ignora quase totalmente as relações informais e a dinâmica de pequenos grupos que ajudam a fazer a vida organizacional 'funcionar'". Nessa perspectiva, o burocrata é um sujeito chave dentro da engrenagem de funcionamento da burocracia estatal na modernidade e sua atuação se dá em um imbricado contexto de relações sociais e arranjos institucionais. Tal ação se torna ainda mais eminente a partir de estudos no campo da Ciência Política e da implementação de políticas públicas (Lipsky, 2010; Cavalcante \& Lotta, 2015) que têm buscado compreender os papéis dos burocratas dentro dos arranjos das instituições estatais, uma vez que eles atuam com discricionariedade para pautar suas decisões e ações. Na subseção seguinte iremos tratar sobre este assunto mais detidamente. 


\section{2 \\ O lugar do gestor escolar na burocracia}

Considerando a atuação do gestor escolar como agente da burocracia do Estado, poderíamos definir este ator escolar a partir de categorias relacionadas ao lugar que ele ocupa na burocracia e nas suas obrigações legais que estão apontadas na literatura sobre os burocratas implementadores de políticas. Ao invés de classificá-lo a priori, deixamos a pesquisa de campo nos apontar como ele se comporta dentro da burocracia para podermos interpretar suas atitudes no contexto escolar. Diante disso e das experiências vivenciadas nas escolas durante o período de observação, percebemos que o gestor escolar se comporta como um burocrata de médio escalão. Por conta disso, a seguir teceremos algumas considerações teóricas sobre este burocrata.

Coadunando com a perspectiva de Giddens (2017) sobre a necessidade de adotar uma visão mais panorâmica sobre a atuação dos burocratas considerando as relações informais e a dinâmica de pequenos na modernidade, Pires (2018) aponta que os formatos organizacionais emergentes que são mais horizontalizados, colaborativos, transversais e com projetos estruturados em rede, amplia a interdependência funcional e a coordenação horizontal para a produção de uma ação coletiva o que, consequentemente, amplia o escopo de influência dos atores situados nas camadas intermediárias da estrutura estatal. Ou seja, o modo como as organizações se estruturam na modernidade por meio de relações sociais horizontalizadas e em rede, faz com que os burocratas de médio escalão assumam um papel central na implementação de políticas públicas.

O burocrata de médio escalão é aquele que ocupa cargos intermediários e é responsável pela gestão de equipes e, por isso, tem agência tanto no âmbito macro quanto no âmbito micro da organização. Além disso, tem a função de tomar decisões e transformar normativas em ações, assumindo papel central na implementação de políticas públicas (Cavalcante \& Lotta, 2015; Lima, 2019). No médio escalão, os burocratas estão situados entre múltiplos outros atores e, assim, gerenciam conexões, interferindo em fluxos de informação, distribuição de recursos e na 
definição dos parceiros considerados mais adequados ou legítimos para atuar nos processos de execução das ações (Pires, 2018).

Soma-se a isso, como fator central de diferenciação dos burocratas de médio escalão em relação às demais categorias que compõem a burocracia pública, seu exercício da discricionariedade no que se refere ao uso dos recursos públicos disponíveis para a implementação das políticas públicas. Embora não lide com os mesmos montantes de recursos disponíveis para a alta burocracia, este burocrata precisa gerir considerável soma de recursos públicos, o que não ocorre entre os burocratas do nível de rua (Oliveira \& Abrucio, 2018).

De acordo com Lotta, Pires e Oliveira (2014), o burocrata de médio escalão desempenha função de "direção intermediária", pois se em determinadas questões se parece mais com o alto escalão - por exemplo, no que tange à liberdade para gerir recursos públicos -, em outras se assemelha àquela do burocrata de linha de frente, especialmente em função de seu eventual contato direto com o público-alvo da política pública que comanda. Oliveira e Abrucio (2018, p.213) esclarecem que

[...] ao contrário da street level bureaucracy, sua atuação não é exclusivamente de atendimento do público-alvo, mas sim de coordenação e comando daqueles que implementam o serviço final. Ademais, a burocracia de médio escalão é a única que lida com as categorias extremas da hierarquia da burocracia pública: tanto com a do alto escalão quanto com a do nível da rua [...].

É possível afirmar então que definir um determinado ator como burocrata de médio escalão é uma caracterização em boa medida relacional, ou seja, depende do contexto em que ele atua, da forma de acesso e recrutamento para o cargo exercido, dos objetivos da política e das atividades e interações de trabalho. Nesta pesquisa, iremos analisar as atitudes do gestor no contexto escolar da rede estadual de Minas Gerais e cujo acesso ao cargo se dá, conforme vimos, via seleção acrescido de um processo de eleição e cujo mandato pode durar até 8 anos, caso haja reeleição. Buscaremos avançar na discussão sobre as interações de trabalho do diretor junto aos servidores da escola e aos demais servidores da SEE/MG, a fim de compreender as formas de atuação do gestor escolar e suas atitudes e influências em relação às políticas públicas educacionais. 
A Superintendência Regional de Ensino (SRE) é o 'braço' da Secretaria Estadual de Educação (SEE) que está mais próximo das escolas estaduais. O elo entre a SRE e a escola é efetivado pelo inspetor escolar que, na SRE de Juiz de Fora, é composto por um quadro de 20 profissionais que desempenham a função de articular, acompanhar, fiscalizar e orientar as políticas que são encaminhadas pelo órgão central (Secretaria Estadual de Educação) junto às escolas.

No âmbito de cada escola o diretor escolar se relaciona com o inspetor escolar da SRE, com o pessoal da secretaria da escola, as especialistas, os vice-diretores, os pais/responsáveis e alunos. Nesse sentido o gestor escolar é o elo entre a escola e a instância superior e, ao mesmo tempo, é aquele que compõe a equipe pedagógica da instituição escolar e se relaciona com alunos e pais/responsáveis. Sendo assim, seu trabalho é desenvolvido por meio de e em interações com outros sujeitos da burocracia escolar. Por conta disso, buscamos em nossa pesquisa de campo compreender como acontece a agência dos diretores no cotidiano escolar.

Como ações de um burocrata de médio escalão observamos que o diretor escolar interagia diretamente com os alunos e pais. Com os pais mais diretamente via reuniões coletivas e atendimentos individuais e com os alunos diariamente em diversos momentos da rotina escolar como, por exemplo, recepção dos alunos na entrada da escola, recreio e atendimento individual, quando necessário.

$\mathrm{Na}$ escola Travessia era mais comum a diretora e o vice-diretor se envolverem em questões de atendimento aos alunos e pais do que, por exemplo, a especialista. Além disso, tanto a diretora quanto o vice-diretor do turno da manhã afirmavam que, por eles conhecerem os alunos da escola e suas famílias, era mais fácil que eles cuidassem e respondessem às demandas de atendimento aos alunos e pais do que a especialista que atuava no mesmo período. Vale ressaltar que a referida especialista está na escola desde 2017, ano em que passou no concurso do estado, ainda assim, de acordo com a diretora e o vice ela ainda não conhecia os alunos da escola e suas famílias. 
Na escola Jardim Botânico, por outro lado, a demanda pedagógica de atendimento a alunos e pais era atendida pela vice-diretora e pelas especialistas. O diretor ficava responsável pela parte administrativa da escola. Embora a escola Jardim Botânico tivesse quase o dobro de alunos, a demanda de atendimento a alunos era muito menor do que na escola Travessia. Durante os 6 meses de pesquisa de campo, todos os dias a diretora e o vice da escola Travessia atendiam alunos e/ou pais/responsáveis para tratar sobre problemas de indisciplina. Já na escola Jardim Botânico era uma média de dois atendimentos na semana. Outra diferença era como a escola se comunicava com os pais. Se na escola Travessia eles mandavam recado pelos alunos chamando os pais/responsáveis para comparecerem na escola, na escola Jardim Botânico era redigido um bilhete convocando os pais/responsáveis do aluno o qual era colado no caderno e deveria vir assinado no dia seguinte. Caso o aluno não trouxesse o bilhete assinado no dia seguinte, eles ligavam para os pais/responsáveis.

As práticas cotidianas observadas nas duas escolas mostram que os diretores escolares agiam com discricionariedade, pois eles podiam distribuir e delegar funções na escola. Por exemplo, a definição legal das atribuições do diretor e do vice-diretor, assim como dos especialistas, especifica que todos respondem pelas demandas pedagógicas na escola, mas a definição de quem fará o atendimento a alunos e pais cabe ao diretor.

Ademais, no trabalho de gestão da escola, o diretor escolar precisa lidar, muitas vezes, com a falta de recursos, de informações e com pressões advindas tanto dos seus supervisores quanto dos cidadãos. No

entanto, o modus operandi do diretor dentro da burocracia escolar é relacional, pois se ora ele atua junto aos pais e alunos, em outros momentos, ele se relaciona cotidianamente, de um lado, com os vicediretores, com o secretário e com a especialista no âmbito micro da organização escolar e, por outro, mais esporadicamente com o inspetor escolar e o superintendente regional.

Durante as observações feitas nas escolas também foi possível verificar momentos em que o gestor escolar se relacionava com sujeitos externos à escola. Um desses momentos foi, por exemplo, a situação em 
que a gestora escolar da escola Travessia recebeu a visita da inspetora da escola e obteve orientações normativas sobre a política do Jovem de Futuro. Neste caso, a diretora precisou conhecer a política para criar as condições necessárias para colocá-la em prática na escola, além de ter que escolher os atores que iriam atuar na execução das ações da política na escola. Outro momento observado foi quando os diretores foram convocados para se reunirem com a superintendente de Juiz de Fora para receberem informações sobre as novas políticas educacionais do estado.

Diante das considerações feitas, interpretamos o diretor escolar como um burocrata de médio escalão como sugerem os estudos de Motta (2018), Oliveira e Abrucio (2018) e Lima (2019), visto que ora ele se relaciona com os usuários do serviço escolar (pais e alunos), ora com os sujeitos dos âmbitos macro (inspeção escolar) e micro (membros da equipe gestora e professores) da burocracia educacional e escolar. Isso nos leva a crer que, além de ser um sujeito chave no processo de implementação de políticas públicas, sua atuação dentro da burocracia escolar lhe confere poder e uma considerável margem de discricionariedade, pois possibilita que ele faça negociações, gerencie conexões, interfira em fluxos de informação e defina os atores que irão atuar no processo de execução das políticas ou projetos educacionais definidos pela alta burocracia.

No levantamento bibliográfico realizado identificamos algumas categorias que interferem no processo de uso dos dados por parte dos gestores escolares e, ao longo da escrita deste texto, viemos desenvolvendo os argumentos em torno de cada uma delas. Para encerrar este ciclo, é necessário falar sobre como a liderança do diretor e o clima escolar influenciam a dinâmica de uso de dados. É sobre isso, portanto, que trata o próximo capítulo. 


\section{5}

\section{Lideranca, clima escolar e o uso de dados}

Neste capítulo trataremos sobre o sexto e o sétimo fatores que influenciam no processo de uso de dados na escola, a saber: a liderança do diretor e o clima escolar (Figura 16) . A primeira em função de o diretor escolar, uma vez reconhecido como liderança na escola, produzir efeitos que reverberam nas práticas pedagógicas desenvolvidas, no clima da escola e, consequentemente, no aprendizado dos estudantes. A segunda por estar intrinsecamente relacionada à primeira e ter sido cada vez mais apresentada na literatura como um dado importante para a construção e implementação de projetos e práticas nas escolas.

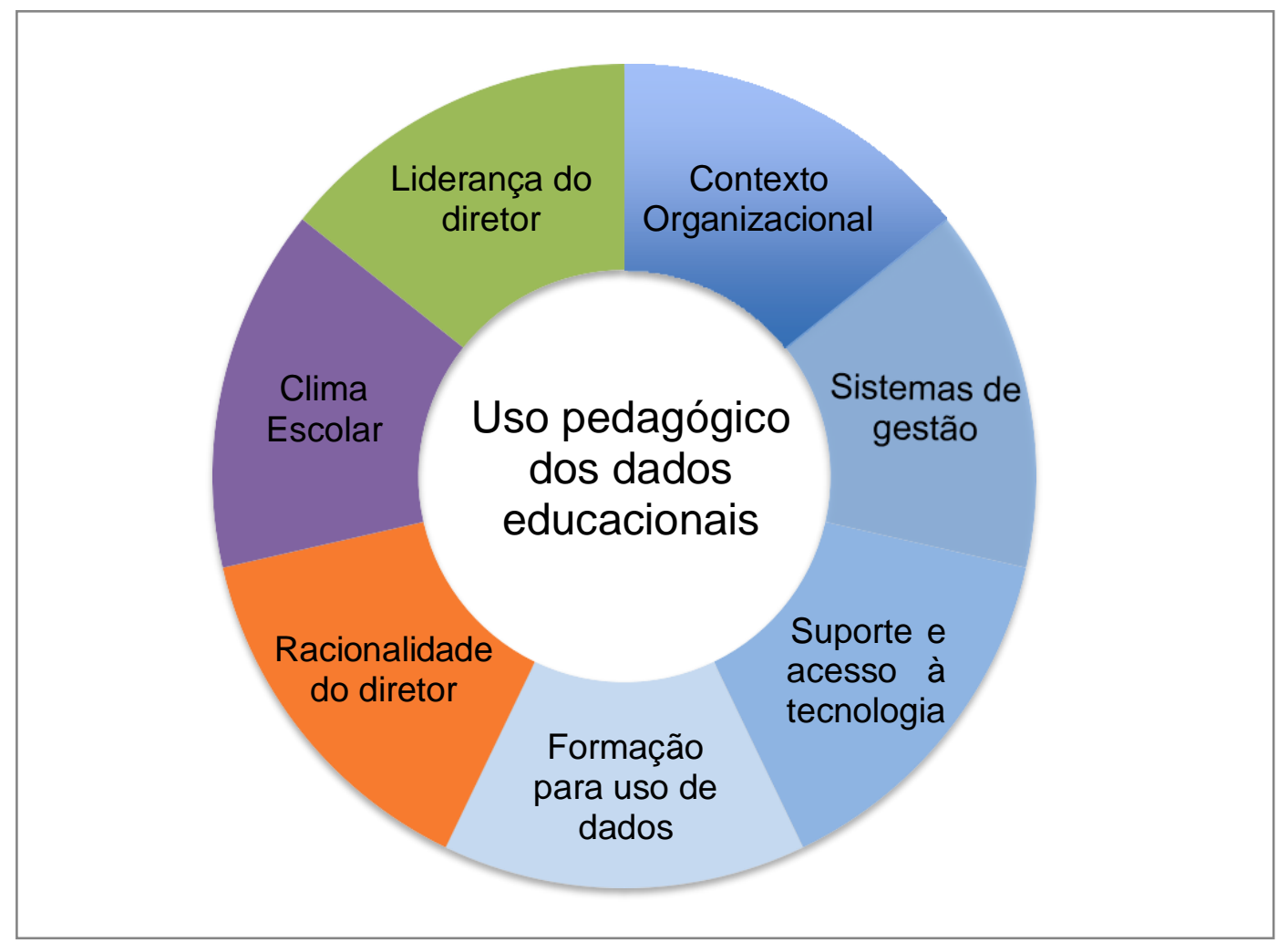

Figura 15 - Fatores que influenciam no processo do uso pedagógico dos dados educacionais na escola

Fonte: Elaborado pela autora (2020).

De acordo com Halverson (2014) e Mandinach e Schildkamp (2020) o uso de dados para tomada de decisão e a liderança do diretor andam juntas e têm sido cada vez mais fomentados no contexto de políticas públicas de responsabilização, inclusive dada a quantidade cada vez maior de dados 
disponíveis para os educadores e escolas. Em função disso, Halverson (2014) afirma que liderança do diretor assume duas direções. Em uma delas, os líderes escolares são responsáveis pela implementação e pelo gerenciamento de sistemas de dados que indicam o grau em que as práticas de ensino dentro da escola produzem resultados que satisfazem demandas da rede escolar e das comunidades locais. Na outra direção, os líderes devem trabalhar com os professores para gerar dados formativos e construir comunidades profissionais que informam as práticas locais de ensino e aprendizagem, fornecem feedback aos alunos e inspiram novos caminhos para a inovação do ensino. Todavia, estabelecer e manter este duplo papel da liderança está claramente além do escopo do que os líderes formais ${ }^{21}$ podem fazer sozinhos e representa como a liderança transformacional (Leithwood \& Jantzi, 1999) pode contribuir para o desenvolvimento de capacidades e comprometimento na organização escolar por meio de redes de práticas colaborativas.

O clima escolar, por sua vez, é influenciado pelas práticas de liderança exercidas na escola e é um dado crucial para contextualizar os dados de aprendizagem na escola. Por conta disso, Mandinach e Gummer (2016) afirmam ser fundamental que os dados sobre o clima escolar sejam incluídos nas análises sobre o de uso de dados para gerar ações pedagógicas na escola. No cenário nacional, algumas pesquisas, que exploraremos ao longo deste capítulo, corroboram a importância do clima escolar como um dado que influencia o processo de ensino e aprendizagem na escola.

Inicialmente apresentamos o conceito de liderança adotado, bem como a perspectiva de liderança escolar que escolhemos para subsidiar nossas análises. Feito isso, apresentamos o modelo integrado sobre domínios e práticas de liderança para, ao final, expor alguns reflexos da atuação da liderança na escola e sua relação com o uso de dados. $\mathrm{Na}$ seção seguinte, apresentamos o levantamento bibliográfico realizado por Piton e Machado (2019) acerca do clima escolar e descreveremos os elementos constituintes do clima escolar elaborados por Oliveira (2015) e

21 Na literatura anglo-saxônica, via de regra, os diretores são denominados líderes, independentemente de seu reconhecimento como tal pelos demais atores escolares. 
que serviram como meio para 'mensurarmos' o clima das escolas pesquisadas.

\section{1}

\section{Liderança Escolar}

Os gestores escolares de maneira geral e, especialmente os da rede estadual de educação de Minas Gerais, possuem obrigações e responsabilidades administrativas e pedagógicas junto às escolas, definidas legalmente. Logo, os gestores escolares, em função das múltiplas atividades que exercem na escola, são concebidos enquanto líderes da instituição.

Apesar de estudos sobre liderança aparecerem na agenda de pesquisa internacional desde a década de 1970, somente a partir da década de 1990 o tema se tornou objeto sistemático de pesquisas empíricas em contextos educacionais (Leithwood \& Jantsi, 1999). A complexidade de sentidos que envolvem o termo liderança faz dele algo difícil de conceituar, principalmente, se levarmos em consideração as subjetividades dos seguidores do líder. Ou seja, é difícil haver consensos sobre as qualidades e características para que a mesma pessoa seja percebida ou considerada como líder para grupos sociais diferentes. Cientes dessas dificuldades optamos neste trabalho por trabalhar com o conceito de liderança na escola descrito por Leithwood (2009) como o: "trabalho de mobilizar pessoas e influenciar outros para articular e alcançar as intenções e metas compartilhadas na escola" (Leithwood, 2009, p. 20, tradução nossa). Tal escolha justifica-se na medida em que o autor é reconhecido na literatura como uma das referências internacionais mais citadas e reconhecidas sobre o tema.

Corroborando com esta visão trabalhamos com a perspectiva da liderança transformacional para compreender a liderança do gestor escolar. Conforme apontam Leithwood e Jantzi (1999), a liderança transformacional contribui para o desenvolvimento de capacidades e comprometimento na organização escolar e, por isso, é fator crucial para que as políticas públicas focadas na melhoria dos resultados escolares possam, de fato, ser 
implementadas e contribuam para o desenvolvimento de uma educação de qualidade.

O modelo de liderança transformacional desenvolvido por Leithwood e Jantzi (1999) inclui seis dimensões de liderança e quatro dimensões administrativas. As primeiras dizem respeito a: construção da visão e dos objetivos da escola; prover estímulo intelectual; oferecer suporte individualizado; simbolizar práticas e valores profissionais; demonstrar altas expectativas em relação ao desempenho; e desenvolver estruturas para promover a participação nas decisões escolares. Já as dimensões administrativas incluem: a equipe escolar; o suporte instrucional, o monitoramento das atividades escolares e o foco na relação família-escola.

Contudo, em artigo publicado mais recentemente, Leithwood et al. (2019), após revisitar o modelo mencionado acima e realizam uma extensa pesquisa na literatura sobre liderança escolar, propõem um modelo que integra os diferentes domínios e práticas da liderança transformacional na escola. Na Tabela 2 apresentamos como este modelo articula em quatro domínios de prática, 19 práticas específicas.

\begin{tabular}{|c|c|}
\hline $\begin{array}{c}\text { Domínios de } \\
\text { prática }\end{array}$ & Práticas específicas \\
\hline $\begin{array}{c}\text { Estabelecer } \\
\text { direções }\end{array}$ & $\begin{array}{l}\text { - } \quad \text { Construir uma visão compartilhada; } \\
\text { - } \quad \text { Identificar objetivos específicos, compartilhados e de } \\
\text { - } \quad \text { Criar altas expectativas em relação ao desempenho; } \\
\text { - } \quad \text { Comunicar a visão e objetivos. }\end{array}$ \\
\hline $\begin{array}{l}\text { Construir } \\
\text { relações e } \\
\text { desenvolver } \\
\text { pessoas }\end{array}$ & $\begin{array}{l}\text { - } \quad \text { Estimular o crescimento das capacidades } \\
\text { - } \quad \text { Frofissionais dos funcionários; } \\
\text { - } \quad \text { membecer suporte e demonstrar consideração por } \\
\text { - } \quad \text { Construividuais da equipe; } \\
\text { os funcionários, alunos e pais; } \\
\text { - Estabelecer relações de trabalho produtivas com o } \\
\text { professor. }\end{array}$ \\
\hline
\end{tabular}

Tabela 2 - Domínios e práticas da liderança transformacional (continua) 


\begin{tabular}{|c|c|}
\hline $\begin{array}{l}\text { Desenvolver a } \\
\text { organização } \\
\text { para apoiar as } \\
\text { práticas } \\
\text { desejadas }\end{array}$ & $\begin{array}{l}\text { - } \quad \text { Construir cultura colaborativa e distribuir liderança; } \\
\text { - } \quad \text { Estruturar a organização para facilitar a colaboração; } \\
\text { - } \quad \text { Construir relacionamentos produtivos com famílias e } \\
\text { - } \quad \text { Comunidades; } \\
\text { - } \quad \text { Manter um ambiente escolar seguro e saudável; } \\
\text { - } \quad \text { Alocar recursos em apoio à visão e objetivos da } \\
\text { escola. }\end{array}$ \\
\hline $\begin{array}{l}\text { Melhorar o } \\
\text { programa } \\
\text { institucional }\end{array}$ & $\begin{array}{l}\text { - } \quad \text { Equipar o programa de instrução; } \\
\text { - } \quad \text { Fornecer suporte instrucional; } \\
\text { - } \quad \text { Monitorar a aprendizagem dos alunos e o progresso } \\
\text { da melhoria escolar; } \\
\text { - } \quad \text { Proteger a equipe de distrações para seu trabalho de } \\
\text { instrução. }\end{array}$ \\
\hline
\end{tabular}

Tabela 2 - Domínios e práticas da liderança transformacional (conclusão)

Fonte: Leithwood et al. (2019, p. 4, tradução nossa).

Para os autores, o modelo integrado de liderança transformacional apresenta de que maneira as dimensões administrativas e de liderança se associam e, assim, esclarece a importância de se refletir sobre as ações do gestor escolar uma vez que elas acontecem dentro de uma teia de relações pessoais e contextuais.

Diversas pesquisas têm buscado compreender as repercussões das ações de liderança do gestor escolar e as suas consequências na comunidade escolar. Em 2008, Leithwood, Harris e Hopkins, publicaram um artigo intitulado Seven Strong Claims about Successful School Leadership no qual apresentaram sete afirmações que relacionavam a liderança do gestor escolar com alguns aspectos da escola. De acordo com os autores, estas afirmações repercutiram mais do que o esperado na comunidade acadêmica. Por conta disso, no ano de 2020, eles publicaram o artigo Seven Strong Claims about Successful School Leadership revisited retomando as sete afirmativas a partir de pesquisas empíricas sobre liderança escolar para oferecer novas ideias e perspectivas para análises no campo. Discutimos, a seguir, estas afirmativas e em que medida elas foram modificadas ou ratificadas.

A liderança escolar tem efeito significativo nas características da organização escolar o que influencia positivamente a qualidade do ensino e da aprendizagem. 
Embora moderado, esse efeito de liderança é vital para o sucesso da maioria dos esforços de melhoria escolar (Leithwood et al., 2020, p. 6, tradução nossa).

Diferentemente da versão inicial, que dizia que a liderança escolar perdia apenas para o ensino em sala de aula como fator de influência na aprendizagem dos alunos, esta afirmativa apresenta argumentos mais relacionais e interligados do que imperativos. Em outras palavras, entendese que a liderança tem efeito na organização escolar e esta, por sua vez, afeta positiva e indiretamente a qualidade do ensino e a aprendizagem ao invés de apenas afirmar que a liderança influencia a aprendizagem dos alunos.

A segunda assertiva "quase todos os líderes de sucesso usam o mesmo repertório de práticas de liderança" (Leithwood et al., 2020, p. 8 , tradução nossa) foi reforçada por estudos empíricos empreendidos desde a publicação do artigo de 2008. Dessa forma, ela reitera os domínios e práticas apresentadas na Tabela 2.

De acordo com Leithwood et al. (2020) algumas pesquisas têm destacado a importância dos líderes escolares serem responsivos aos diversos contextos (profissionais, materiais, econômicos, políticos) a que estão submetidos ao invés de serem moldados por eles. Sendo assim, o líder escolar deveria sempre se perguntar 'dadas essas condições, o que eu devo fazer?'. Diante disso, a terceira asserção é: 'O modo como os líderes aplicam as práticas de liderança mostra sua capacidade de resposta aos contextos em que trabalham" (Leithwood et al., 2020, p. 9, tradução nossa). Sendo assim, observar as diferentes estratégias que o gestor escolar mobiliza no seu cotidiano permite descortinar como eles adaptam estratégias pedagógicas frente às contingências contextuais.

A partir das práticas de liderança (Tabela 2), Leithwood et al. (2019) construíram o "Four Paths Model" (modelo de quatro caminhos), representado na Figura 14, e aplicaram um survey com 1.779 professores de 81 escolas do Texas com o objetivo de ajudar a compreender a influência da liderança e das 13 variáveis no processo de ensino aprendizagem.

Os autores observam que já existem evidências suficientes que apontam que a liderança influencia o aprendizado dos estudantes e que 
essa influência ocorre de maneira indireta (Leithwood et al., 2019). A variável racional estava ancorada nos conhecimentos e habilidades dos membros da equipe escolar; a emocional inclui os sentimentos, as disposições ou estados afetivos de membros da equipe, tanto individuais quanto coletivos, que poderiam moldar a natureza de seus trabalhos; a organizacional inclui as características das escolas que estruturam as relações e interações entre os membros da organização; e a as variáveis da família incluem as características da moradia que são alteráveis e mostraram contribuições significativas para o sucesso dos alunos em escola.

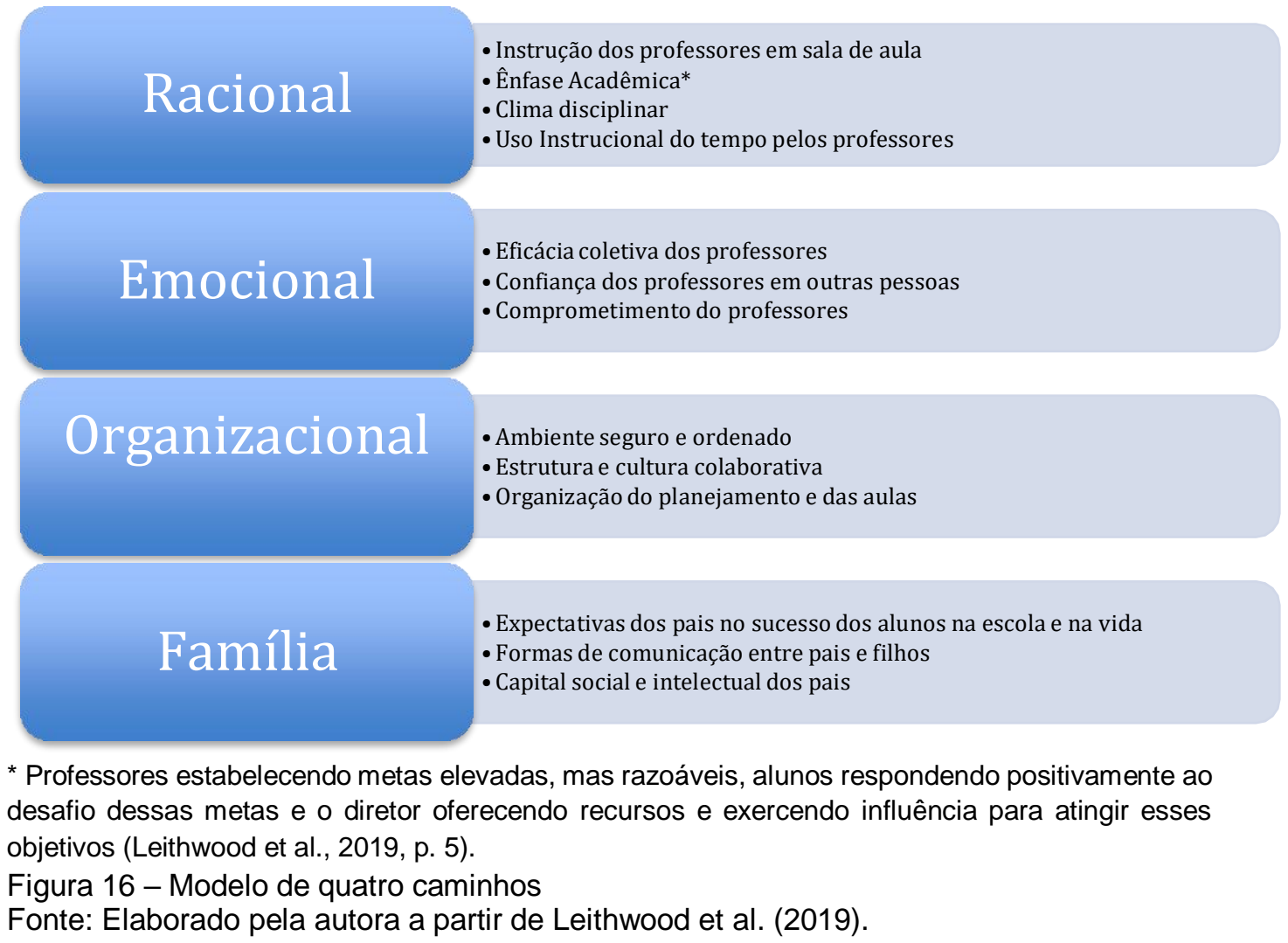

As análises do survey buscaram compreender qual das variáveis de cada um dos 'quatro caminhos' mais influenciavam no desempenho dos alunos. No 'caminho racional' a que mais influencia o desempenho dos alunos é o clima disciplinar seguido pelo uso instrucional do tempo pelos professores. No 'caminho emocional' a eficácia coletiva dos professores é a variável que mais influencia no aprendizado dos estudantes; já no 'caminho organizacional' foi o aspecto relacionado ao ambiente seguro e 
ordenado; e, por fim, no 'caminho família' a influência maior é do capital social e intelectual dos pais. Com base, então, neste estudo e em outras pesquisas (Goodall, 2017 e 2018; Leithwood et al., 2017; Leithwood et al., 2017; Leithwood et al., 2010, Leithwood, et al., 2020) revisaram a quarta afirmativa que ficou da seguinte forma:

\footnotetext{
A liderança escolar melhora o ensino e a aprendizagem indiretamente e muito poderosamente, ao melhorar as condições escolares e de sala de aula e encorajar as interações pais/filhos em casa que, a longo prazo, aumentam ainda mais o sucesso do aluno na escola. (Leithwood et al., 2020, p. 12, tradução nossa).
}

As afirmativas cinco e seis (dentre as sete enunciadas na obra anterior) versam sobre a natureza e importância das formas de liderança distribuída na escola e não sofreram alterações mesmo depois dos autores analisarem diversos outros estudos. Sendo assim, elas permaneceram com a seguinte redação: "A liderança escolar pode ter uma influência especialmente positiva nos resultados da escola e dos alunos quando é distribuída"; e "alguns padrões de distribuição são mais efetivos do que outros." (Leithwood et al., 2020, p. 13, tradução nossa).

Por fim, a afirmativa 7 após ser revisada coloca que: "Embora mais pesquisas sejam necessárias, um conjunto bem definido de "recursos de liderança pessoal cognitivos, sociais e psicológicos são promissores para explicar uma alta proporção de variação nas práticas realizadas por líderes escolares." (Leithwood et al., 2020, p. 14, tradução nossa). Essa afirmativa se baseia em pesquisas que, de alguma maneira, buscaram identificar algumas habilidades de liderança. Os estudos têm apontado que recursos cognitivos, sociais e psicológicos podem influenciar as práticas de liderança exercidas na escola. $\mathrm{Na}$ Tabela 3 apresentamos tais recursos e as respectivas habilidades de liderança. 


\begin{tabular}{c|ll}
\hline Recursos & & \multicolumn{1}{c}{ Habilidades } \\
\hline \multirow{3}{*}{ Cognitivos } & - Expertise em resolver problemas; \\
& - Domínio de conhecimentos específicos; \\
\hline \multirow{2}{*}{ Sociais } & - Pensamento sistêmico. \\
& - Percepção de emoções; \\
& - Agir de maneira emocionalmente adequada; \\
\hline \multirow{2}{*}{ Psicológicos } & - Otimismo; \\
& - Auto-eficácia; \\
& - Resiliência; \\
\hline
\end{tabular}

Tabela 3 - Recursos e habilidades de liderança

Fonte: Leithwood et al. (2020, p. 15, tradução nossa).

Importante esclarecer que as habilidades de liderança, por si só, não explicam uma alta proporção de variação na eficácia da liderança escolar (LEITHWOOD et al., 2020). Ou seja, ainda que o gestor escolar tenha essas habilidades, o modo como ele lida com cada uma delas e as coloca em funcionamento dentro do contexto que vivencia são aspectos subjetivos e que moldam de diferentes formas sua ação gestora na escola.

No campo da pesquisa educacional nacional, a discussão sobre liderança e gestão escolar é recente e, na maioria das vezes, atrelada a estudos sobre escolas eficazes (Oliveira, 2015). Todavia, desde 2010 pesquisas têm sido empreendidas pelo Grupo de Pesquisa em Gestão e Qualidade da Educação (GESQ/PUC-Rio), na busca de compreender a relação entre liderança e gestão escolar, como se pode apreender da apresentação de alguns destes estudos a seguir.

Oliveira e Waldhelm (2016), por meio dos dados contextuais da Prova Brasil de 2013, buscaram compreender a possível relação existente entre a liderança do diretor e o clima escolar com o desempenho em Matemática dos alunos do $5^{\circ}$ ano das escolas municipais e estaduais do Estado do Rio de Janeiro. As autoras encontraram um impacto estatisticamente significativo da liderança do diretor (definida a partir da percepção dos professores) e das condições de trabalho dos docentes (tipo de vínculo profissional com a escola) nos resultados de Matemática do $5^{\circ}$ ano do Ensino Fundamental. Ou seja, escolas onde os professores apresentaram 
uma percepção mais positiva sobre a liderança do diretor, apresentaram melhores resultados nos testes de Matemática de seus alunos do 5ํㅡㅁ ano. Da mesma forma, escolas que apresentaram uma percepção mais positiva dos professores sobre o clima escolar, também apresentaram melhores resultados nos testes de Matemática de seus alunos do $5^{\circ}$ ano.

Tais resultados reforçaram aqueles encontrados por Oliveira (2015) em escolas municipais do Rio de Janeiro, no qual a percepção dos professores sobre 0 ambiente escolar associava-se positiva $\mathrm{e}$ significativamente com os resultados de aprendizagem dos alunos e com o nível de satisfação dos professores no trabalho. Frente a isso, podemos dizer que, assim como nas pesquisas internacionais mencionadas anteriormente, também no contexto brasileiro a gestão escolar, a liderança e o clima escolar são fatores intraescolares que podem influenciar positivamente a aprendizagem dos alunos.

Avançando na discussão, o estudo empreendido por Oliveira e Paes de Carvalho (2018) buscou aprofundar o conhecimento a respeito da associação entre um fator intraescolar - liderança do diretor, medida por meio da percepção dos professores sobre ele e seu trabalho na gestão - e um fator extraescolar - as políticas de provimento do cargo de direção da escola - com os resultados do $5^{\circ}$ ano em Matemática em diferentes edições da Prova Brasil (edições de 2007, 2009 e 2011). Os resultados indicaram uma associação positiva entre o desempenho médio em matemática no $5^{\circ}$ ano e a liderança dos diretores. Em contrapartida, foi constatado uma associação negativa entre os mesmos resultados de desempenho com a gestão de diretores nomeados nas escolas (em grande parte dos casos por indicações políticas).

A discussão sobre liderança escolar nos mostrou que ao influenciar outras variáveis na escola como as relações interpessoais no ambiente escolar e a relação família-escola ela tem um peso significativo sobre o aprendizado do aluno. Além disso, indicou que existem habilidades de liderança possíveis de serem identificadas, mas que não necessariamente, garantem uma liderança eficaz. Diante disso, iremos compreender as práticas de liderança exercida pelos diretores no dia a dia da escola e a forma como elas são colocadas em prática diante dos contextos a partir do 
modelo integrado de liderança transformacional. Isso porque, por outro lado, como o levantamento bibliográfico sobre o uso de dados mostrou, a liderança do diretor é fundamental para que o uso dos dados se torne uma prática na escola e seu conhecimento e habilidade em usar os dados é importante para que o corpo docente também conheça e utilize os dados. O planejamento e a tomada de decisão com base em dados dependem fortemente de uma liderança que os apresente e coloque como pauta para sustentar a discussão sobre o ensino-aprendizagem e a organização do trabalho escolar que repercutam no desenvolvimento do projeto pedagógico com os profissionais da escola.

No domínio de práticas relativas ao estabelecimento de direções foi possível observar que na escola Travessia havia um engajamento da diretora para a construção de uma visão compartilhada da escola e comunicada à comunidade escolar no intuito de fortalecer a imagem da escola junto a seus usuários. A visão de escola que se pretendia passar realçava a importância da instituição no processo de formação de cidadãos "aquela cara mais cidadã da escola" (Diretora escola Travessia. Entrevista realizada em agosto de 2019). Para a diretora e a equipe de gestão a motivação para a construção desta visão da escola se justificava, em grande parte, pelo fato de a escola atender a um público oriundo das quatro comunidades mais pobres de Juiz de Fora e, assim, o trabalho sobre a importância da escola para a formação era um meio para atrair os alunos e para dizer que o estudo poderia significar, futuramente, melhores oportunidades de emprego. De acordo com o vice diretor

[...] a gente tá numa comunidade carente e passar para o menino alguma boa perspectiva de futuro, que ele tem perspectiva de futuro fora o que o mundo oferece que é a questão da criminalidade, a questão do tráfico de drogas que tá enraizado no dia a dia da nossa comunidade, entende? Então, se a gente conseguir desconstruir essa ideia do dinheiro fácil, do ganho fácil, que na verdade não é nada fácil, e mostrar para ele que com educação, com a escolarização, que não é uma coisa a curto prazo é uma coisa médio, longo prazo que ele vai ter sucesso, eu me dou por satisfeito. Se eu conseguir que esse menino saia ou não entre na criminalidade eu me dou por satisfeito, você está entendendo? Esse menino não precisa ser engenheiro, ele não precisa ser professor, ele não precisa, não. Se eu conseguir tirar ele do caminho da criminalidade eu já me dou por satisfeito. (Vice Diretor Travessia. Entrevista realizada em setembro de 2019). 
Em uma das entrevistas que realizamos com a diretora ela afirmou que o grande problema da escola, no início do seu primeiro mandato, era a violência e os assaltos que aconteciam. Por conta disso, ela fez um trabalho de conscientização da comunidade sobre a importância da escola e, para isso, criou a página do facebook da escola que ela alimenta constantemente com informações e fotos e, também convidou os pais/responsáveis para fazerem parte das ações da escola. Segundo ela: "abri as portas e os muros da escola" para a comunidade que ajudou na pintura interna da escola e na oferta de cursos a partir das habilidades dos pais. Além disso, foi criado o grêmio estudantil para que os alunos pudessem pensar em iniciativas e projetos para a escola como, por exemplo, o Cine Clube que acontece mensalmente no turno da noite e é aberto para toda a comunidade.

Criar altas expectativas em relação ao desempenho escolar e identificar objetivos específicos correlatos, compartilhados e de curto prazo, ainda são desafios para a diretora do nosso ponto de vista. Isso porque, de acordo com ela, o objetivo principal é fazer com que os alunos não entrem ou saiam da rede de tráfico de drogas que existe nos arredores da escola: "Se eu consigo tirar ele do tráfico e mostrar pra ele que existe um outro mundo que ele é capaz de ter, eu já estou, sabe, satisfeita [...].". A preocupação reside, assim, em manter o aluno frequente na escola e longe do tráfico.

Nesse contexto social e territorial em que se encontra a escola Travessia e considerando a visão compartilhada da gestão e dos demais atores escolares sobre a escola e a 'resposta' que ela pode ou deve dar à realidade de seus alunos, pensar especificamente sobre os dados de desempenho parece se tornar secundário e se traduz em baixas expectativas dos professores quanto ao aprendizado dos alunos. Na sala dos professores, inclusive, eram constantes as reclamações em relação às turmas e a afirmação de que os alunos não querem nada com os estudos e estão na escola para lazer.

Os dados disponíveis sobre a escola Travessia parecem espelhar o foco na permanência e não nos demais processos pedagógicos. Assim, para cada 100 estudantes da escola Travessia, 53 estão em distorção 
idade série nos anos finais do ensino fundamental e com médias de desempenho nos níveis mais baixos tanto no Saeb quanto no Simave, o que pode, futuramente, favorecer o abandono ou a evasão.

Outro aspecto relacionado às práticas de liderança transformacional diz respeito à construção de uma cultura colaborativa na escola. Durante a pesquisa de campo na escola Travessia foi possível perceber que entre os professores, entre eles e a equipe gestora, assim como entre a equipe gestora e os demais funcionários, havia uma rede de práticas de colaboração. Os projetos e ações voltados para as famílias e para os alunos contavam com o envolvimento de todos como, por exemplo, a Festa Junina e as atividades no Dia das Crianças. A Festa Junina era, segundo a diretora, o grande evento do ano no qual a escola abria as portas para receber os alunos e suas famílias e havia grande participação e comprometimento de todos na organização e na execução das tarefas no dia. Assim como a Festa Junina o Dia das Crianças era outro grande evento que tinha como foco chamar as famílias para irem na escola e, por conta disso, a diretora investia nesta iniciativa alugando brinquedos e oferecendo brincadeiras e brindes para as crianças. Contudo, no que dizia respeito à iniciativa de pensar projetos voltados especificamente para o aprendizado, esta ficava restrita à execução dos projetos da SEE. Como dissemos antes, os Itinerários e o Jovem de Futuro foram projetos que, durante a pesquisa, estavam em fase de execução, os quais, em contraste com os demais desenhados pela equipe da escola, alcançaram pouca colaboração, inclusive pelos 'ruídos' no processo de implementação na escola desde o momento inicial.

No que diz respeito às práticas de suporte instrucionais e de monitoramento da aprendizagem dos alunos, por tudo que apresentamos até aqui, podemos afirmar que elas são um problema na escola Travessia. A observação de campo mostrou que praticamente não há um planejamento da equipe gestora relativo às atividades pedagógicas na escola como a realização de reuniões em função de o cotidiano da escola ser conturbado. Isto é, não há planejamento pedagógico por conta do clima da escola e, por não haver planejamento pedagógico o clima da escola não melhora. De acordo com o especialista 
Então, reunião marcado não. Até porque a gente se encontra todo dia na escola, então a gente está sempre em contato e tem um grupo de WhatsApp só dos diretores e dos supervisores. Então determinados assuntos que precisa discutir entre a gestão ficam nesse grupo (...) às vezes uma discussão pelo WhatsApp já poupa o trabalho de você ter que marcar uma data para poder vir todo mundo estar presente. Até porque são seis pessoas. Seis. E é difícil conseguir um horário que coincida para todo mundo tá presente participando. (ESPECIALISTA TRAVESSIA. Entrevista realizada em setembro de 2019).

A gestora ficava a maior parte do tempo resolvendo problemas de conflito entre alunos e professores e entre alunos, e atendendo aluno que chega na sala da direção para pedir coisas. Os alunos, muitas vezes, chegavam na escola sem material escolar (caderno, lápis, borracha, etc.) e vinham cotidianamente pedir para a diretora; além disso, no inverno, muitos chegavam sem roupa de frio na escola e a diretora se preocupava em achar no almoxarifado da escola algum casaco e calça para eles. Em função destes acontecimentos a rotina priorizada na escola era a assistencial e, por isso, não necessariamente havia uma falta de planejamento, já que para planejar é preciso identificar prioridades e achar que elas são importantes o suficiente para planejar e alcançá-las. Diante disso, tanto a especialista quanto a diretora não tinham um tempo reservado para verificar as demandas que precisariam resolver e nem para reuniões com os membros da escola que aconteciam sempre por demanda, isto é, se surgia alguma coisa que precisasse ser resolvida em conjunto, eles sentavam e discutiam naquele momento. Tal situação foi observada em diversas ocasiões na escola, mas relataremos uma delas.

\footnotetext{
O vice diretor do turno da manhã chegou cedo na escola para acompanhar a entrada dos alunos e verificar se todos os professores haviam chegado para dar aula. Feito isso, ele foi atender o pai de um aluno do tempo integral. Logo depois a diretora chegou e o vice diretor informou a ela que havia problemas de lançamento de notas e conteúdos no DED e que eles precisavam resolver porque o prazo para lançamento era no dia seguinte. Seguiram para a sala da coordenação pedagógica para usar o computador. Chegando lá havia um aluno esperando para pedir caneta. Depois a diretora conversou com a especialista para dizer que eles receberam uma cobrança da SRE sobre o não lançamento das informações no DED da disciplina de Ensino Religioso. A especialista faz login no sistema do DED e reclama que é complicado, pois tem que preencher tudo novamente, cada vez que volta para a tela inicial. Um professor chega na sala e chama a especialista. Ela sai. A diretora e o vice assumem o preenchimento do DED e ela afirma "vou enfartar aqui", pois eles não estavam conseguindo fazer os lançamentos no DED. Nesse momento chega o ASB para dizer que uma aluna desmaiou e os dois saem para resolver essa situação. Em seguida, eles retornam para preencher o DED e a especialista diz que
} 
precisa resolver problema de uma aluna que estava na sala $A$ ao invés da $B$ onde ela está enturmada e que já volta. Durante o preenchimento do DED pela direção aparece um aluno reclamando que a professor liberou alguns alunos para o horário de educação física e outros não. A diretora pede para ele esperar, pois uma mãe chega pedindo a liberação de uma aluna para ir para casa. Resolvido isso, eles voltam para o preenchimento do DED e não conseguem lançar o conceito, pois dá erro dizendo que o conteúdo não foi lançado. Descobrem, então, que precisam fazer o lançamento turma por turma. A diretora sai para conversar com a professora de Ensino Religioso e, ao retornar, o vice diz que não conseguiu fazer o lançamento de uma turma e ela sugere que eles liguem para a Sedine. Chega a ATB financeira para falar com a diretora que o serralheiro veio entregar a grade, mas que afirmou que não faria a instalação. A diretora sai para conversar com ele. Um pouco antes do horário do recreio eles conseguem resolver os problemas de lançamento no DED e, em seguida, o vice e a diretora saem para ajudar a servir a comida para os alunos na cantina. Depois do recreio a diretora fica na sua sala durante uma hora e, neste tempo, atende três alunos. (Anotações do diário de campo feitas em agosto de 2019).

Esse relato de campo é ilustrativo do cotidiano da escola que, apesar de ter dias mais tranquilos, comumente era tumultuado. Sobre a divisão de tarefas entre a equipe gestora, de acordo com o vice diretor ela funciona da seguinte forma:

[...] essa divisão de tarefas ela é muito importante dentro da gestão escolar porque a gente não consegue fazer tudo é sozinho então assim a diretora gosta muito dessa parte de projetos e isso toma muito tempo porque hoje na era da informática tudo é ligado ao computador, é ligado a plataforma, é ligado a sistemas. Então a diretora costuma pensar muito nos projetos, mas nós temos quase 900 alunos e esses alunos estão em sala de aula e a gente precisa manter o bom andamento das aulas, manter a disciplina dentro da escola, então eu costumo brincar que eu sou o operacional. (Vice diretor travessia. Entrevista realizada em setembro de 2019).

Vale esclarecer que os projetos a que ele se refere eram relacionados à construção de propostas para conseguir verbas para a escola e/ou aqueles previstos no calendário escolar como a festa junina, semana de prevenção às drogas e semana de educação para a vida, que não se relacionavam diretamente com a busca da melhoria do aprendizado dos alunos.

Dentre os recursos e habilidades de liderança apontados por Leithwood et al. (2020) podemos afirmar que a diretora da escola Travessia apresenta algumas das habilidades de cada um dos recursos. Dentre as habilidades de cada recurso foi possível perceber que ela tinha habilidade em resolver problemas, em gerenciar emoções e tinha proatividade para com as necessidades da escola. Nesse sentido podemos concluir que a 
diretora da escola Travessia é uma liderança no contexto da escola, principalmente, pelo aspecto social, de construção de relações e de envolvimento com os alunos e suas famílias.

Na escola Jardim Botânico a dinâmica do cotidiano e das relações entre os sujeitos que estão na escola era bastante diferente da escola Travessia. O diretor da escola Jardim Botânico tinha uma rotina de trabalho. Sua rotina ao chegar na escola era cumprimentar o pessoal da secretaria, os vices diretores e as especialistas uma vez que suas salas ficavam próximas à dele para, em seguida, ir para sua sala. Lá ele ligava o computador e verificava o e-mail da escola e se havia demandas que ele precisava resolver no Simade. Dependendo do dia da semana ele poderia ter reuniões com a ATB financeira, com os vices e/ou especialistas. Mas ele ficava a maior parte do tempo na sua sala resolvendo demandas administrativas e de infraestrutura do prédio da escola. O ASB, responsável pela manutenção da escola, sempre vinha falar com o diretor sobre coisas que precisavam ser feitas e obter autorização para tal.

\begin{abstract}
De manhã, exceto um dia, na quarta, porque eu fico mais à tarde na escola e à noite então nesse dia eu não venho de manhã, mas eu tenho uma rotina né a primeira coisa é assinar a documentação da escola para nada ficar parado, seja na área financeira, seja na área de pessoal, seja na área de documentação para a superintendência primeira coisa é atender os ofícios, a legislação, calendários, preenchimento virtuais que eu tenho que fazer. Feito essa questão de não ter nenhum documento aqui pra eu assinar, eu parto para aquela questão do dia, né, se tem algum atendimento que elas (especialistas) não vão fazer se eu tenho algum atendimento, eu não começo a trabalhar sem saber se tem algum atendimento para eu fazer. Posto isso, não tem atendimento, não tem nada a gente senta pra ver a demanda dentro daquela perspectiva, né: SIMADE, e-mails, DED, transferência de recurso e hoje a gente também está inserido num programa Jovem de Futuro, então, eventualmente a partir desse ano a gente tem feito alguns cursos à distância, então eu tenho que reservar um horário pra esses cursos a distância. Já fizemos um que é dentro dessa área do estado Pessoal, Pedagógico, Financeiro e Administrativo. E a gente está no Jovem de Futuro, além de fazer as reuniões com a inspetora e os outros participantes que são alunos e professores eu tenho esse curso a distância que eu tenho que me deter a ele, reservar algum tempo para ele, e ao longo do dia aparecem essas questões ai né: uma folha A4, uma mãe que chega aqui [...]. (Diretor Jardim Botânico. Entrevista realizada em novembro de 2019).
\end{abstract}

A parte relativa à orientação, ao acompanhamento, a implementação e a avaliação do processo de ensino-aprendizagem na escola eram feitas pelas especialistas junto com as vices diretoras. O diretor monitorava os acontecimentos através do DED, do Simade e das reuniões com elas e, 
quando necessário, intervia no processo junto a elas. E, por conta disso, podemos afirmar que ele fazia uma gestão pedagógica através dos dados.

[...] a parte pedagógica é esse acompanhamento, por exemplo, como eu me aproximo da parte pedagógica? Eu tenho acesso ao Diário Digital e ao SIMADE eu fico olhando essas questões, como está o preenchimento porque a ausência de algum dado é porque o professor ou ainda não inseriu os dados ou não fez, então ele tem um prazo para inserir para que eu saiba que aquela turma fez um trabalho, fez uma avaliação, teve chance de uma entrevista, olhou caderno, recebeu um ponto de conceito, fez uma pesquisa, participou de uma mostra de ciências, quando eu vejo esses relatos aqui no DED eu imagino que o professor esteja trabalhando em sala de aula. (Diretor Jardim Botânico. Entrevista realizada em novembro de 2019).

A dinâmica do funcionamento da escola era construída dentro de uma cultura colaborativa e de uma distribuição de responsabilidades e liderança que produzia relacionamentos de confiança, conforme afirma o diretor.

[...] nós temos o regulamento do estado, né a gente tem uns pilares que a gente não pode deixar de ter isso em mente, nós atendemos o Pessoal, o Administrativo, o Financeiro e o Pedagógico e eu tenho que estar a par disso tudo, mas eu tenho uma pessoa no Pessoal e no Administrativo que é o meu secretário, tem o tesoureiro que me ajuda na parte Financeira e tenho dois vices que me ajudam muito na parte Pedagógica então eles ficam mais atentos a essa questão pedagógica: calendário, provas, resultados, diário digital, permanência do aluno, evasão de aluno, resultados internos, resultados das provas é externas, das diagnósticas... então tem dois que ficam muito atentos a essas questões, reuniões de módulos, reuniões de conselho de classe, é normalmente eles sempre estão na frente disso eu participo uma parte e eles me ajudam nessa parte (...) mas normalmente a gente divide uma preocupação e eu tenho que saber das quatro partes, mas cada um deles fica mais atento a uma. (Diretor Jardim Botânico. Entrevista realizada em novembro de 2019).

Além disso, o diretor acompanhava a aprendizagem dos alunos e monitorava o progresso da melhoria escolar. Tais ações aconteciam por meio da observação eventual das aulas; pelo Simade no qual ele tinha acesso aos resultados das avaliações externas; e pelo DED no qual estavam registrados os resultados das avaliações internas e a frequência dos alunos.

$\mathrm{Na}$ escola Jardim Botânico o diretor tinha uma preocupação em estruturar a instituição e, para tanto, alocava recursos financeiros com despesas de infraestrutura. A seguir apresentamos alguns trechos de fala que ilustram essas ações. 
[...] a escola só tinha um telefone nós compramos um jogo com quatro pontos então as pessoas não se levantam mais, hoje você tem câmeras, hoje você tem sensor para abrir o portão as pessoas não precisam se levantar mais para abrir o portão e a escola hoje tem ferramentas [...], nós compramos mobiliário, [...] nós conseguimos, através de projetos, uma verba para uma internet mais rápida. (Diretor Jardim Botânico. Entrevista realizada em novembro de 2019, grifo nosso).

[...] uma das deficiências da escola é o atendimento na secretaria eu tive que refazer o pensamento das pessoas eles atendiam as pessoas sentados. Eu falei não, levanta, vai lá, anote o nome da pessoa. Não fique perguntando de novo, retorne para a pessoa, pede o telefone dela, diz para ela não ficar esperando que ela pode ir para casa que você vai retornar para ela e retorne. Conseguimos uma linha de celular para escola com recurso próprio a gente paga com o dinheiro das nossas festinhas. (Diretor Jardim Botânico. Entrevista realizada em novembro de 2019, grifo nosso).

[...] o atendimento na secretaria mudou muito. Lá elas têm os melhores equipamentos da escola. $\mathbf{O}$ melhor xerox está lá, o melhor computador está lá. Elas tem até produtos contra insetos para não se sentirem mal, entendeu? Tem o spray, o remedinho e tem o lanche. (Diretor Jardim Botânico. Entrevista realizada em novembro de 2019, grifo nosso).

Considerando os quatro campos de domínios de práticas elencados por Leithwood et al. (2019) podemos afirmar que o diretor da escola Jardim Botânico exerce uma liderança transformacional. Além disso, foi possível observar que ele possui os recursos cognitivos, sociais e psicológicos e as respectivas habilidades de liderança descritas por Leithwood et al. (2020). Contudo, vale ressaltar que o modo como o diretor lida com as habilidades e as coloca em funcionamento dentro da escola são de caráter subjetivos e, como vimos, influenciados pela racionalidade do diretor e pelo contexto organizacional que ele gere.

As habilidades de expertise em resolver problemas, dominar conhecimentos específicos e ter pensamento sistêmico foram observados durante a pesquisa na escola Jardim Botânico na medida que ele detinha os conhecimentos e as ferramentas para resolver os problemas da escola e mobilizava recursos para tanto. $O$ fato de ele repensar a estrutura da escola melhorando $o$ atendimento na secretaria e equipando a escola com ramais telefônicos, uma linha de celular e um plano melhor de internet demonstra seu pensamento sistêmico para bom funcionamento da escola, bem como quando distribuía as demandas pedagógicas, financeira, administrativa e de pessoal entre a equipe gestora. Dessa forma, o diretor criava condições de funcionamento da equipe, a fim de que ela se sentisse 
como equipe e colaborassem efetivamente (e de forma confiável) com ele.

Segundo o diretor

[...] as pessoas também tiveram um encantamento com a minha administração por que eu sei mexer em quase tudo da escola até na cozinha se faltar cozinheira eu consigo ajudar, sei mexer com ferramentas, entendo um pouco da rede lógica, sei mexer com a parte elétrica, hidráulica, então, por exemplo, elas não ficam sem um telefone porque deu problema eu ajudo a mexer, se elas não estão conseguido ver um negócio de um computador a gente ajuda a mexer não que eu entenda de tudo, mas eu procuro entender um pouco de cada coisa e isso ajudou muito a confiança e quando tem um líder que trabalha as outras partes têm que trabalhar se não elas ficam sem espaço aqui dentro, né? (Diretor Jardim Botânico. Entrevista realizada em novembro de 2019, grifo nosso).

Neste excerto fica explícito que o diretor se percebe eficaz na medida em que ele conhece de tudo um pouco e acha isso fundamental para o bom funcionamento da instituição escolar. Mas também ele ressaltou em diferentes momentos da entrevista que ele nunca está sozinho, que tem sempre uma equipe junto dele e que a coesão entre as pessoas é que faz com que as coisas deem certo. Como exemplo, ele relatou que os alunos chegam na escola cedo e, muitas vezes, sem comer. Então, ele, juntamente com a equipe gestora, resolveram oferecer um lanche para os alunos assim que chegassem de manhã para a aula, mas para dar certo, essa causa teria que ser abraçada por todos. Assim, ele promovia o trabalho colaborativo, via liderança distribuída, e com foco no aluno.

[...] um exemplo é o lanche, todo mundo associou que esse lanche é bom para os alunos então a forma de servir tem que ser boa, o suco tem que ser bom, a carne tem que ser boa, o pão tem que ser fresco de hoje, tudo e todos encantaram com esse processo. Então eu poderia imaginar um lanche desse, mas a cozinheira não gostasse aí já poderia não dar certo. (Diretor Jardim Botânico. Entrevista realizada em novembro de 2019).

Nesta seção sobre liderança do diretor apresentamos o referencial teórico que subsidiou nossas reflexões para a coleta e análise dos dados da pesquisa de campo. Realizamos, então, as análises que indicaram que ambos os diretores são lideranças nas suas escolas e possuem domínios e habilidades de liderança que são exercidas em conjunturas distintas e a partir de diferentes visões de escola e de aluno. Isso demonstra que, assim como o modo de agir do diretor dentro da burocracia é híbrido, o modo como ele exerce a liderança é relacional, pois mesmo que ele domine 
certas práticas e demonstre certas habilidades, o contexto escolar no qual ele atua irá influenciar nas suas práticas de liderança. Leithwood et al. (2020) destacam a necessidade de os líderes escolares serem responsivos aos contextos profissionais, materiais, econômicos e políticos ao invés de serem moldados por eles. Nesta pesquisa foi observado que os diretores adotavam diferentes estratégias de liderança frente às demandas contextuais.

A escola Travessia, por exemplo, está inserida no meio de comunidades muito pobres de onde provém seus alunos. A diretora lida cotidianamente com alunos que (sobre)vivem em bairros com alto índice de violência, tráfico de drogas e pobreza. Seus esforços de liderança estão voltados para que os alunos permaneçam na escola e, para isso, busca construir ações voltadas para os alunos e suas famílias. Por outro lado, na escola Jardim Botânico, o diretor precisa lidar com um contexto externo à escola bem diferente da escola Travessia. Seus alunos são provenientes de diversos bairros adjacentes, mas nenhum com alto nível de pobreza o que, consequentemente, faz com que os problemas da escola sejam outros e isso parece favorecer, ao menos em parte, a adoção de outras prioridades pela equipe gestora. Nesta escola não há alunos que não tenham material escolar e calçados para ir para a escola. Pelo contrário, todos possuem uniformes e alguns deles fazem uso da van escolar como transporte. Diante disso, os esforços de liderança do diretor são canalizados para outras prioridades. Por tudo isso, nos importa destacar que o contexto interno da escola absorve demandas do contexto externo e, assim, o modo de se exercer a liderança dentro da escola se torna diferente.

No que tange especificamente à relação entre o uso de dados pedagógicos na escola e a liderança vimos no levantamento bibliográfico realizado que esta última é primordial para que o uso dos dados se torne uma prática na escola e que o conhecimento e a habilidade do diretor em usar os dados é fundamental para que o corpo docente também se torne participante deste processo. Por conta disso, a tomada de decisão com base em dados depende fortemente de uma liderança que apresente os dados e os coloque como pauta para serem discutidos com os profissionais da escola. 
Nas duas escolas que fizeram parte desta pesquisa não foi observado um movimento dos diretores em relação à apresentação de dados sobre aprendizagem e fluxo, por exemplo, como pauta de discussão com os demais membros na escola. Os momentos nos quais os dados foram mobilizados diziam respeito ao cumprimento de ações referentes às políticas públicas como os Itinerários e o Jovem de Futuro, ou seja, seu uso era mobilizado para cumprir uma obrigatoriedade (im)posta pelas políticas e pela SEE/MG e, por isso, não faziam parte do cotidiano da escola. $\mathrm{Na}$ verdade, é preciso esclarecer que havia um monitoramento dos dados por parte da equipe gestora que verificavam se os professores lançavam os dados no DED e, por isso, prática de uso dos dados tinha um caráter muito mais fiscalizatório do que, de fato, pedagógico.

Segundo Farrell (2015) os sistemas de gestão per si não promovem o uso instrucional dos dados e para que este uso se efetive é necessário mais do que os sistemas, é necessário que a liderança escolar tenha os conhecimentos e as habilidades para identificar questões, analisar resultados e criar soluções factuais. Ademais, o autor afirma que os educadores escolares não só precisam de apoio, mas também de autoridade suficiente para tomar decisões com base em dados. Na escola Travessia o uso de dados passava ao largo da diretora que, como já explicitamos, no dia a dia da escola tinha que 'apagar incêndios' (gestão de contingência) toda hora e, por conta, inclusive, de uma falta de priorização e planejamento, não tinha tempo para esse tipo de demanda.

De acordo com Gois (2020) bons diretores constroem objetivos comuns, desenvolvem pessoas, investem em laços com a comunidade, estabelecem relações de confiança, são focados nas ações pedagógicas e procuram criar um bom clima escolar. Além disso, vimos com base nos estudos de Leithwood et al. (2020) que a liderança escolar tem efeito sobre a organização escolar e, como consequência, influencia positivamente na qualidade do ensino e da aprendizagem e, ao investir na relação famíliaescola, aumenta ainda mais as chances de sucesso dos alunos na escola. Dito isto, fica explícita a relação entre liderança e clima escolar e, por isso, iremos na seção seguinte expor este fator. 


\section{2 \\ Clima Escolar}

Falar sobre clima escolar requer identificar a escola enquanto organização e significa olhar para as múltiplas relações entre os sujeitos da esfera escolar - gestores, professores, famílias e alunos. Ao longo da pesquisa identificamos que o clima escolar, ainda que indiretamente, estava imbricado nos demais fatores mapeados quanto ao uso de dados instrucionais. Quando pensamos em formação para uso de dados, em liderança e em uso dos sistemas, por exemplo, estamos falando indiretamente em clima escolar na medida em que é necessária uma cultura escolar voltada para um objetivo comum, no caso a melhoria da aprendizagem, para que esses fatores influenciem o uso de dados para fins instrucionais na escola. Isto é, se faz necessário que o clima da organização escolar estimule esses processos.

O estudo do tipo estado da arte realizado por Piton e Machado (2019) inventariou os artigos publicados nos periódicos Capes sobre o tema clima escolar. Nesse levantamento, embora não se tenha estabelecido marcos temporais, identificou-se que o primeiro artigo científico sobre clima escolar foi publicado em 2003 e o último em 2018 - ano final da busca. Neste período de tempo foram encontrados 76 artigos nacionais e internacionais e observou-se um aumento das pesquisas acerca do clima escolar, principalmente a partir de 2011. Contudo, a maior parte das publicações (63 artigos) foram em periódicos internacionais e o restante (13 artigos) nas revistas de origem nacional. Além disso, somente nove dos 76 artigos publicados tratavam sobre o tema clima escolar no Brasil e foram estes estudos que os autores leram na íntegra. Vale ressaltar, que um destes nove trabalhos foi o de Oliveira e Waldhelm (2016) que apresentamos na seção anterior.

A pesquisa empreendida por Silva e Bizon (2017) constatou que grande parte das produções nacionais e internacionais tratavam do efeito negativo do bullying no clima escolar e o papel desempenhado pelos docentes com suas implicações na prevenção, identificação e intervenção no bullying. Outros trabalhos cujo foco foi analisar a relação entre 
professores e clima escolar foram os de Silva et al. (2010); Brito e Costa (2010); Grigoli et al. (2010).

A pesquisa de Silva et al. (2010) identificou que há uma correlação entre as relações interpessoais dos docentes e da violência com o clima escolar. Ou seja, escolas cujos professores não possuem boa relação interpessoal e não promovem ações para prevenir a violência, o clima escolar tende a ser ruim. Já a pesquisa de Brito e Costa (2010) analisou a relação entre professores, gestão e responsáveis, concluindo que tais relações pessoais são fatores consideráveis para um bom clima escolar. Por fim, Grigoli et al. (2010) identificaram que trabalho em equipe, relações democráticas, porte pequeno das escolas, compromisso com aluno, gestão democrática e estímulo aos professores, objetivos e compromissos compartilhados são fatores que contribuem positivamente para o clima escolar.

Por outro lado, o estudo de Cunha (2014) focou na violência testemunhada pelos alunos de escola públicas do município do Rio de Janeiro e o clima escolar. A autora conclui que há uma relação negativa entre clima e escolas consideradas violentas. Ou seja, nas escolas em que foram relatadas mais ocorrências de violência pelos alunos, o clima escolar é avaliado de maneira negativa.

A partir da observação etnográfica em uma escola pública considerada eficaz no bairro Jacarepaguá no Rio de Janeiro, Soares et al. (2013), analisaram em que medida o componente curricular Educação Física poderia colaborar na formação e configuração do clima escolar e contribuir para a chamada eficácia escolar. Como conclusão os autores apontam que tal disciplina exerce uma influência de mão dupla no clima escolar uma vez que, ao mesmo tempo que ajuda na construção de um clima positivo na escola, é esse clima bom que faz com que os alunos queiram fazer tal disciplina. Além disso, os autores apontam o papel da liderança do gestor como fator positivo na forma como a escola se estrutura o que, consequentemente, se reflete no clima escolar.

Rocha e Perosa (2008) consideraram que um clima escolar positivo depende tanto de fatores intraescolares, como as relações interpessoais, quanto de fatores extraescolares a saber: estabilidade do cargo e bom 
salário. Por último, mas não menos importante, Silva e Bris (2007) realizaram uma revisão bibliográfica sobre o clima de organizações educacionais e identificaramm diferentes conceitos de clima escolar. Concluem dizendo sobre a importância de estudos sobre o clima organizacional nas escolas para analisar as interações sociais que podem facilitar ou dificultar o trabalho entre os diferentes atores do processo pedagógico.

Ao final do artigo, Piton e Machado (2019) destacam a escassez de publicações científicas sobre clima escolar no Brasil e ressaltam a necessidade de incentivo para pesquisas sobre essa temática já que elas podem contribuir sobremaneira para pensarmos novas formas de organização e estruturação da instituição escolar.

A partir do exposto destacamos a importância de analisar 0 componente clima escolar e relacioná-lo com a forma como os gestores organizam a sua rotina e utilizam (ou não) os dados escolares no planejamento das suas atividades. Para compreender este processo na organização escolar, o conceito de clima escolar que norteou esta pesquisa foi aquele apresentado por Silva (2001, p. 52) como um "[...] conjunto de efeitos subjetivos percebidos pelas pessoas, quando interagem com a estrutura formal, bem como o estilo dos gestores escolares, influenciando nas atitudes, crenças, valores e motivação dos professores, alunos e funcionários".

Tendo isso em vista, utilizamos os elementos constituintes do clima escolar elaborados por Oliveira (2015) como meio para 'mensurarmos' o clima das escolas pesquisadas. Importante ressaltar que, enquanto a pesquisa de Oliveira (2015) utilizou os elementos constituintes do clima escolar para elaborar um questionário que foi aplicado a diretores, coordenadores e professores, nesta pesquisa fizemos uso dos mesmos como guia de leitura para os dados coletados nas entrevistas e anotados no diário de campo.

Oliveira (2015) apontou como elementos constituintes do clima escolar: um ambiente próprio para aprendizagem, as relações interpessoais, coesão do corpo docente, a comunicação e a satisfação no trabalho. Tais elementos dialogam fortemente com os aspectos 
encontrados por Piton e Machado (2019) no estado da arte sobre clima escolar o que reforça, ainda mais, a pertinência em utilizá-los para esta pesquisa.

O primeiro elemento se relaciona a estrutura da organização e, por isso, engloba aspectos relativos a um ambiente agradável e estimulante cujo funcionamento acontece em um ambiente próprio para as tarefas escolares, isto é, com um clima de ordem orientado para as tarefas escolares (Oliveira, 2015). Ambas as escolas estão submetidas à mesma estrutura formal enquanto organização, mas a forma como os sujeitos interagem com essa estrutura configura diferentes tipos de clima escolar.

$\mathrm{Na}$ escola Travessia, o ambiente estava sempre limpo e conservado, mas as interações cotidianas entre os sujeitos que compunham a organização escolar pareciam tornar om clima desordenado ou tendendo a isso expresso, frequentemente, na forma como as pessoas gritavam umas com as outras para se comunicar. Se o porteiro precisava se comunicar com a diretora, ele "gritava" por ela ou para alguém para saber onde ela estava e, da mesma forma, era assim que a equipe gestora se comunicava quando queria chamar algum aluno. Toda manhã o vice diretor da escola Travessia acompanhava a chegada dos alunos e dos professores na escola. Assim que o sino tocava, ele encaminhava os estudantes para as salas de aula e, ao mesmo tempo, verificava se todos os professores haviam chegado. Caso algum professor faltasse, ele assumia a turma. No intervalo para o recreio todas as turmas do ensino fundamental anos finais e ensino médio desciam juntas e, por conta disso, quem chegasse primeiro na fila comeria primeiro e teria mais tempo livre depois. Desse modo, assim que o sino tocava era uma correria pelas escadas rumo à fila da merenda o que, por sua vez, sempre gerava confusão e os alunos ficavam agitados. Portanto, podemos afirmar que o clima da escola Travessia é agitado e, em certa medida, desordenado.

Na escola Jardim Botânico, havia um ordenamento nas práticas da escola. O horário de recreio e de entrada e saída dos alunos eram desencontrados para que os alunos dos $8^{\circ}$ e $9^{\circ}$ anos não encontrassem com os dos $6^{\circ}$ e $7^{\circ}$ anos e sempre havia alguém da equipe gestora acompanhando. Segundo o diretor essa foi uma forma de reduzir, pelo 
menos por alguns minutos, o fluxo de alunos e facilitar, a título de exemplo, a dinâmica da entrega da merenda. Sem tumulto na fila, esta andaria mais rápido e os alunos teriam mais tempo para comer. Ademais, para pegar a merenda os alunos entravam por um lado da cantina e saíam pelo outro evitando, assim, de ficarem se esbarrando. Caso algum professor se ausentasse, quem assumia a turma era a vice direção ou a especialista do turno. Nesta escola, portanto, o clima era mais tranquilo, ordenado e os alunos mais calmos.

As relações interpessoais, apontadas por Oliveira (2015) como segundo elemento constituinte do clima escolar, dizem respeito às relações entre a gestão da escola e professores, alunos e especialistas. A partir das observações e das entrevistas feitas podemos afirmar que, a despeito dos tipos de liderança conforme apontamos, os diretores têm um bom relacionamento com os especialistas. De acordo com eles,

\begin{abstract}
[...] tanto a diretora quanto o vice falam que eu tenho apoio total para o que eu quiser fazer, que eles não vão me questionar se eu quiser tomar alguma decisão no sentido de suspender um aluno, de dar uma advertência, de fazer alguma atividade paralela. Eles estão do lado o tempo todo, sabe, não discutem, não questionam. Então assim, é uma relação muito horizontal mesmo. A gente está muito junto nisso, sabe? (Especialista Escola Travessia. Entrevista realizada em setembro de 2019).

[...] eu estou no céu com a minha atual gestão, sem brincadeira, porque uma gestão que ela te dá liberdade, ela cobra? Cobra muito. O diretor é uma pessoa extremamente pontual com as coisas dele, não sei se você já conseguiu perceber isso aqui, ele é uma pessoa muito responsável, muito pontual e, assim, eu costumo falar que é uma aprendizagem trabalhar com ele. Eu aprendo um pouco todo dia. Ele é um gestor, talvez pela experiência dele em empresa, ele é um gestor diferenciado. (Especialista Escola Jardim Botânico. Entrevista realizada em outubro de 2019).
\end{abstract}

Sobre a relação entre os diretores e os professores podemos afirmar que a diretora da escola Travessia tinha uma relação mais próxima do que o diretor da escola Jardim Botânico. Isso porque a primeira sempre estava presente na sala dos professores e conversava com eles sobre as turmas e sobre os projetos da escola. Já o diretor da escola Jardim Botânico frequentava a sala dos professores no intervalo do recreio e os cumprimentava e conversava, mas quem lidava diretamente com os professores no que dizia respeito aos aspectos pedagógicos era a vice direção e as especialistas. A relação entre os diretores e os alunos também 
era positiva, mas pautadas por diferentes práticas. No caso da escola Travessia, uma vez que a diretora tinha uma trajetória anterior como professora e trabalhava na escola há 15 anos, sendo seis como diretora, ela conhecia a escola, os alunos e suas famílias. Sua relação com eles era, portanto de acolhimento, tanto que as pessoas da escola a viam como uma "mãe para aqueles meninos". Em contrapartida, a relação do diretor da escola Jardim Botânico com os alunos era pautada pelo respeito, em suas próprias palavras "aqui os meninos não dão muito trabalho como você pode ver. Há uma relação de medo/respeito em relação a equipe gestora (direção e vice)."

No tocante à coesão do corpo docente buscamos perceber a colaboração entre os professores e entre estes e a gestão da escola, além dos aspectos relativos aos processos de comunicação que, segundo Oliveira (2015), são relevantes para a análise já que podem expressar as práticas de gestão democrática na escola. Tanto na escola Travessia quanto na escola Jardim Botânico havia um ambiente de colaboração entre os professores, uma vez que observamos que eles discutiam sobre o andamento das aulas nas turmas que lecionavam, trocavam ideias sobre estratégias de ensino e pensavam em ações que poderiam ser feitas conjuntamente como, por exemplo, quando um mesmo conteúdo poderia ser abordado por diferentes disciplinas sendo que, cada uma, daria destaque àquele conteúdo que Ihe era relativo. Entretanto, no que dizia respeito à relação entre a equipe gestora e os professores em termos pedagógicos havia diferenças entre as escolas. Na escola Travessia, conforme explicitamos, sobrava pouco tempo para os especialistas conversarem com os professores e, por isso, os momentos de suporte pedagógico se restringiam aos horários de Módulo $\|^{22}$ que, normalmente, acontecia uma vez por mês, aos sábados. Na escola Jardim Botânico os vices diretores conjuntamente com as especialistas acompanham mais de perto o trabalho dos professores e, para além dos horários de Módulo II,

\footnotetext{
${ }^{22}$ As reuniões de Módulo II são de cumprimento obrigatório pelos professores e devem ser programadas pela Direção Escolar, em conjunto com os Especialistas de Educação Básica, para o desenvolvimento de temas pedagógicos, administrativos ou institucionais de forma a atender às diretrizes do Projeto Político Pedagógico.
} 
sempre que preciso, conversavam com eles e estavam disponíveis para dar suporte pedagógico.

Sobre os aspectos comunicativos, diante do que foi observado nas escolas, podemos dizer que a comunicação e a divulgação de informações entre os funcionários da escola Travessia e da Jardim Botânico aconteciam durante os intervalos de aula, quando alguém da equipe gestora ia na sala dos professores dar algum recado; via quadro de avisos da escola e pelo grupo de whatsapp. Já o processo de comunicação entre professores e alunos era bom e ocorria no cotidiano da escola.

Por último, a pesquisa realizada nos permite afirmar que os dois diretores estavam satisfeitos no desempenho da sua função. Era perceptível o compromisso deles com a escola e com os seus membros, apesar de terem, como vimos, visões e objetivos diferentes para as escolas. Além disso, ambos estavam cumprindo seu terceiro mandato como diretores da instituição e pretendiam continuar futuramente.

Nesta seção analisamos o clima das escolas com a intenção de compreender, a partir de alguns elementos apontados por Oliveira (2015), como o clima define e redefine práticas na escola. Vimos que as escolas possuem climas distintos e que isso reverbera em diferentes tipos de relações interpessoais e, como consequência, em distintas práticas nas escolas. Além disso, a relação entre clima escolar e modos de liderança do diretor foram corroboradas na medida em que uma interfere na outra quando, por exemplo, a forma como a organização da escola se estrutura, a partir da liderança do diretor, reflete sobre o clima escolar.

No capítulo que segue propomos a inclusão de um novo fator associado ao uso instrucional dos dados qual seja, a confiança. 


\section{6 \\ Confiança nos dados e o uso de dados}

Finalmente neste capítulo propomos um oitavo fator como influente no uso dos dados na gestão escolar - a confiança nos dados. Construímos teoricamente os argumentos para este fator a partir do referencial do Anthony Giddens ${ }^{23}$ sobre a lógica de funcionamento da modernidade, principalmente, a partir das categorias de desencaixe e confiança com o intuito de compreender alguns aspectos da modernidade. Em seguida, usamos a confiança como uma categoria que influencia o potencial uso pedagógico dos dados educacionais nos processos de tomada de decisão. Por conta disso, nosso fluxograma final fica da seguinte forma.

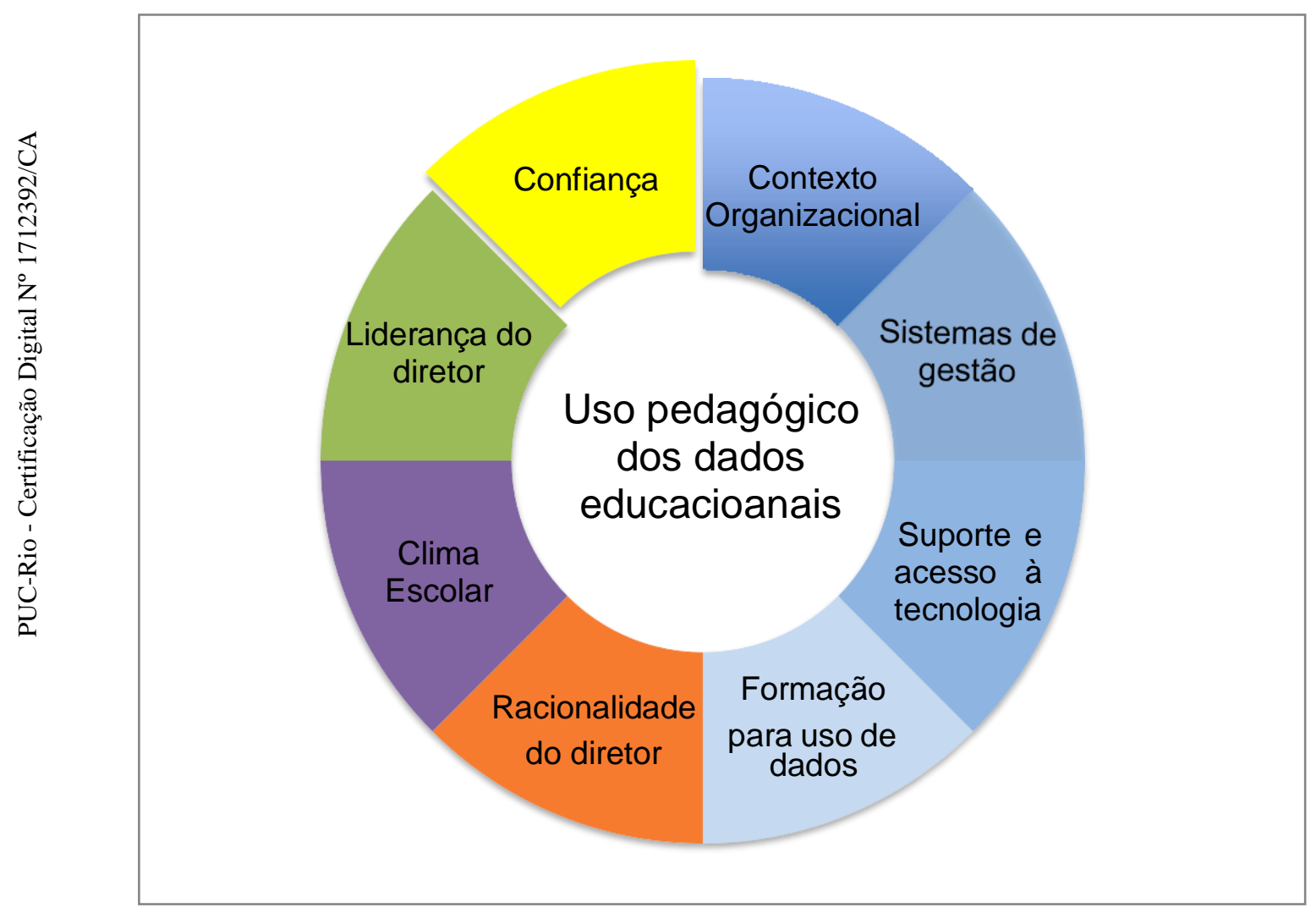

Figura 17 - Modelo de análise do uso de dados educacionais Fonte: Elaborado pela autora (2020).

\footnotetext{
${ }^{23}$ De acordo com Dias (2005, p.87) "Giddens não segue a orientação de alguns autores que nomeiam a sociedade contemporânea como pós-moderna ou pós-industrial. Em vez disso, prefere a terminologia modernidade alta ou tardia, para indicar que os princípios dinâmicos da modernidade ainda se encontram presentes na realidade atual.".
} 


\section{1 Modernidade e Confiança}

Na obra As consequências da modernidade, Anthony Giddens (1991) considera que as instituições sociais modernas são únicas e, por isso, desenvolve uma análise institucional da modernidade. Para tanto, argumenta ser necessário examinar a modernidade sob alguns aspectos: suas descontinuidades, as transformações do tempo e do espaço, os mecanismos de desencaixe e a confiança.

De acordo com Giddens (1991) o modo de vida moderno desvencilhou as pessoas dos tipos tradicionais de ordem social e, por isso, ele analisa este processo identificando três tipos principais de descontinuidades que separam as instituições modernas das ordens tradicionais sociais. A primeira delas diz respeito ao ritmo de mudança já que, como argumenta o autor, na modernidade a rapidez da mudança é extrema. A segunda descontinuidade seria o escopo da mudança visto que ela atinge áreas do globo que, anteriormente, não seriam alcançáveis. Desse modo, a transformação social penetra todo o mundo. Por fim, o autor aponta a natureza intrínseca das instituições modernas uma vez que, a modernização não transcorre de maneira única e uniforme pelas diversas regiões do globo.

No que diz respeito à transformação do tempo e do espaço Giddens (1991) afirma que nas culturas pré-modernas o tempo e o espaço estavam vinculados. Dificilmente o marcador temporal vinha desconectado de "marcadores socioespaciais: "quando" era quase universalmente, ou conectado a "onde" ou identificado por ocorrências naturais regulares." (GIDDENS, 1991, p. 21). Na modernidade, porém, a invenção do relógio e a difusão do seu uso foram elementos essenciais para construir a separação entre tempo e espaço. Isso porque o tempo agora era marcado pelo relógio e, como consequência, não precisaria mais estar vinculado a um lugar ou acontecimento. O tempo tornou-se "vazio" e, por conta disso, disponível para outras quantificações como, por exemplo, "períodos" do dia ou "jornadas de trabalho". A separação entre tempo e espaço foi crucial para o dinamismo da modernidade, pois permitiu o 'desencaixe' dos 
sistemas sociais e possibilitou a liberalização da organização racionalizada da vida social moderna.

Giddens (1991, p. 24) conceitua desencaixe como "deslocamento das relações sociais de contextos locais de interação e sua reestruturação através de extensões indefinidas de tempo-espaço". Assim, no lugar das antigas relações face a face, na modernidade, as relações sociais estão cada vez mais ligadas e condicionadas a grupos de pessoas que, talvez, nunca veremos. Para o autor, existem dois mecanismos de desencaixe que estão intimamente envolvidos no desenvolvimento das instituições: as fichas simbólicas e os sistemas perito e, ambas, dependem da confiança.

As fichas simbólicas são "meios de intercâmbio que podem ser 'circulados' sem ter em vista as características específicas dos indivíduos ou grupos que lidam com eles em qualquer conjuntura particular" (GIDDENS, 1991, p. 25) e, junto a isso, elas precisam transmitir confiança. Como exemplo de ficha simbólica o autor apresenta o dinheiro uma vez que ele vincula tempo-espaço e "transmite" confiança independente da presença dos indivíduos.

Por sistema perito Giddens (1991, p. 30) se refere "a sistemas de excelência técnica ou competência profissional que organizam grandes áreas dos ambientes material e social em que vivemos". Frente a isso, a pessoa que faz uso do sistema perito é desprovida de competência técnica e profissional daquele sistema e, por isso, precisa confiar nele. Um exemplo seria o sujeito que embarca em um avião e, a despeito dos riscos envolvidos e do seu não conhecimento técnico sobre aviões, ele confia no sistema.

A categoria da confiança que está atrelada aos mecanismos de desencaixe é cara para a reflexão que ora propomos. Na construção conceitual sobre confiança Giddens (1991) aponta que esta pressupõe consciência das circunstâncias de risco, ou seja, no processo de tomada de decisão, mesmo que inconscientemente, a pessoa leva em consideração os riscos envolvidos e, ainda assim, confia e decide. Desde modo, caso as consequências esperadas não sejam alcançadas o indivíduo assume certa responsabilidade, pois estava consciente dos riscos envolvidos. Diante disso, a confiança pode ser definida como "[...] crença 
na credibilidade de uma pessoa ou sistema, tendo em vista um dado conjunto de resultados ou eventos [...]." (GIDDENS, 1991, p. 36).

A confiança, da mesma forma que os mecanismos de desencaixe, relaciona-se à ausência no tempo e no espaço porque confia-se em alguém cujas ações não estão visíveis ou em sistemas que não se conhece ou compreende. Para Giddens (1991, p. 40) "a condição principal de requisitos para a confiança não é a falta de poder, mas a falta de informação plena.".

Explicados, em linhas gerais, os conceitos de fichas simbólicas, sistemas peritos e confiança (GIDDENS, 1991) iremos nos apropriar deles para a construção de um paralelismo entre o uso de dados e as ações dos gestores no âmbito escolar. Dentro da lógica dos mecanismos de desencaixe vislumbraremos os dados disponíveis nos sistemas de gestão e avaliação de Minas Gerais como mecanismo de fichas simbólicas. Isso porque os dados circulam e, na teoria, são confiáveis e não precisam do indivíduo para que isso se confirme, uma vez que o(s) sistema(s) os garantem enquanto tais. Sistemas estes que seriam, no caso específico desta pesquisa, o Sistema Mineiro de Avaliação da Educação Pública

(Simave) e o Sistema Mineiro de Administração Escolar (Simade). Enquanto sistemas peritos eles, por sua vez, funcionam com sentido prático ou objetivo e podem ser usados graças à confiança neles depositada pelos usuários.

O Simave foi implementado no ano de 1992 inspirado na política nacional de avaliação da educação básica, o SAEB. Tinha, pois, o objetivo de gerar um diagnóstico sobre a qualidade do aprendizado na rede estadual mineira e promover uma cultura de avaliação e de utilização dos dados produzidos no planejamento pedagógico das escolas. Este sistema, que está há 28 anos em funcionamento, sofreu alterações ao longo dos anos com a finalidade de se ajustar melhor às necessidades da rede estadual, em função das políticas públicas educacionais que surgiram e de novas propostas curriculares. No site do Simave estão disponibilizados os resultados das provas, bem como informações sobre suas matrizes de referência, os padrões de desempenho esperados e a escala de proficiência. Além disso, o sistema disponibiliza revistas do professor, do gestor e do sistema de avaliação, que contém informações fundamentais 
para a compreensão dos resultados dos exames externos e para sua interpretação pelos atores escolares.

O Simade, por sua vez, foi implementado na rede estadual de educação de Minas Gerais no ano de 2008 a partir da publicação da resolução no 1180 (Minas Gerais, 2008) e, desde então, é o sistema padronizado de gestão de processos administrativos e educacionais informatizado. Ao longo dos 12 anos de operação deste sistema, ele sofreu ajustes e melhoras operacionais a partir do feedback dos usuários nas escolas e, de acordo com Lima (2019), os usuários do Simade o consideram confiável.

Se assumirmos como pressuposto que, na sociedade moderna, a confiança está relacionada à credibilidade em um sistema tendo em vista um conjunto de dados ou eventos (Giddens, 1991), podemos afirmar que ambos os sistemas são confiáveis, assim como os dados deles provenientes tendo em vista que eles existem há, pelo menos, 20 anos Simave - e 12 anos - Simade - dentro da rede estadual mineira.

$\mathrm{Na}$ pesquisa que realizamos nas escolas observamos, assim como Lima (2019), que o Simade era cotidianamente utilizado pela secretaria. $\mathrm{Na}$ escola Jardim Botânico a equipe gestora fazia uso diário do Simade e DED para verificar dados das turmas e alunos em termos de frequência e as demandas administrativas. Na escola Travessia, a diretora acessava pouco o sistema e, geralmente, a secretária ou a ATB financeira avisavam quando algum expediente precisava ser liberado pelo login da direção. O Simade, além de ser um sistema de cunho administrativo que permite um acompanhamento em tempo real do trabalho desenvolvido nas escolas pela SEE/MG e pela SRE, possui dados relativos ao desempenho e frequência discente. Contudo, seu uso nas escolas ficava, muitas vezes, restrito às demandas administrativas.

No que se refere ao uso dos dados do Simave notamos que eles estavam atrelados às políticas do estado como os Itinerários Avaliativos e o Jovem de Futuro e, assim, surgiam como demandas do tipo top down que a escola precisava cumprir. Não havia, no planejamento pedagógico da escola Travessia, um momento reservado para analisar os dados ali disponíveis ainda que esses fossem requeridos pelas políticas 
mencionadas. Já na escola Jardim Botânico, o uso dos dados do Simave aconteciam nos tempos e espaços do cronograma das políticas dos Itinerários Avaliativos. Segundo os relatos dos diretores, o conhecimento sobre o desempenho das escolas nas avaliações externas estaduais acontecia sempre via SRE, isto é, a escola recebia por e-mail os dados de desempenho e os repassava, posteriormente, para os professores nos momentos de reuniões.

Buscamos ao longo desta pesquisa compreender quais seriam as razões para o não uso dos dados para fins pedagógicos e, por isso, levantamos como hipótese que este processo de uso pedagógico poderia não acontecer em função da carência de formação e consequente desconhecimento dos dados ou por uma possível resistência ao processo de avalição externa. Entretanto, durante o processo de análise documental sobre as políticas da SEE/MG para uso dos dados e na pesquisa de campo, percebemos que estas hipóteses não explicavam o porquê do não uso instrucional dos dados para o processo de tomada de decisão nas escolas, posto que a SEE/MG investia em cursos de formação para a equipe gestora voltados, especificamente, para uso dos dados do Simave e que não foram encontradas expressões de resistência ou posicionamento críticos dos gestores das duas escolas em relação aos testes estandardizados.

Assim levantamos uma outra hipótese: o não uso dos dados como parte de um processo pedagógico que incluiria uma reflexão e uma tomada de decisão, poderia estar relacionado à confiança, ou melhor, a não confiança nos dados. Isso porque em uma conjuntura ideal os usuários (equipe gestora) confiariam nos sistemas e nos dados deles provenientes e, com base nas informações disponíveis, realizariam análises e tomariam decisões. Em contrapartida, caso a não confiança nos sistemas e nas informações deles provenientes fosse expressiva, a prática de uso dos dados para fins pedagógicos poderia ficar comprometida e o sistema serviria apenas para consultas formais e para preenchimento de informações necessárias e/ou obrigatórias. Ademais, a confiança é um fator que está vinculado à racionalidade subjetiva, visto que ela está atrelada à crença do indivíduo em alguma coisa. Sendo assim, mesmo que a racionalidade institucional seja formal e instrumental, em última instância, 
cabe ao indivíduo decidir sobre a confiabilidade ou não dos sistemas, consequência da racionalidade valorativa presente no campo da ação dos sujeitos.

Frente a isso, o conceito de confiança que ora mobilizamos está relacionado à confiabilidade de alguma coisa para alguém. No caso específico desta discussão, trata-se da confiança do diretor nos dados provenientes dos sistemas mineiros de avaliação e gestão, que se vincula à racionalidade subjetiva do diretor escolar, pois mesmo que a racionalidade institucional seja formal e instrumental, cabe ao diretor decidir se confia ou não nos dados dos sistemas e deles fazer uso para tomar decisões. Tal confiança ganha ainda mais importância na medida em que, como argumentamos anteriormente, o gestor escolar se configura como um burocrata híbrido e, portanto, dialoga com as instâncias macro e micro dentro dos arranjos institucionais da SEE/MG ao mesmo tempo em que atua como uma liderança na escola.

A ideia de confiança que trazemos para a discussão relaciona-se também, ainda que indiretamente, à identificação ou reconhecimento, ou seja, em que medida os diretores reconhecem e identificam ou não suas escolas nos dados provenientes do sistema. Durante as observações nas escolas ficou claro que, muitas vezes, as equipes gestoras consideram os dados das avaliações internas, elaboradas pelos professores, mais fidedignos do que aqueles das avaliações externas. E isso não significava, por exemplo, que eles não conheciam, em termos técnicos, a metodologia de aplicação dos testes padronizados e as matrizes de referência, mas sim que, em certa medida, eles simplesmente não identificavam suas escolas e seus alunos naqueles dados. Aqui vale dizer que este aspecto estava mais presente na escola Travessia do que na escola Jardim Botânico. E, naquele caso, a justificativa, em grande parte, estava atrelada ao fato de a equipe gestora da Travessia dizer que são eles quem conhecem a realidade da escola, afinal de contas estão ali todos os dias e, os dados externos, não refletem o que eles vivenciam ali.

$\mathrm{Na}$ seção seguinte apresentaremos algumas pesquisas no campo da educação que, de alguma forma, tratam sobre o uso de dados e a confiança para compreender qual sentido eles mobilizam para esta categoria. 


\section{2 Confiança e uso dos dados}

Na tentativa de melhor situar esta discussão, buscamos compreender como as pesquisas no campo da educação tem trabalhado a questão da confiança associada ao uso de dados. Para tanto, procuramos por estudos nas plataformas JSTOR e Scielo a partir das palavras-chave: confiança + uso de dados, confiabilidade + uso de dados, confidence + data use e relyability + data use no título dos trabalhos. Os resultados da busca, majoritariamente, apresentaram artigos cujas discussões se relacionavam a temas da área de estatística como, por exemplo, intervalo de confiança ou, ainda, sobre a importância da qualidade dos dados para uso na tecnologia da informação. Os poucos trabalhos que encontramos na área de educação eram internacionais, a saber: o relatório da Associação Americana dos Administradores Escolares (American Association of School Administrators) do ano de 2002, o relatório de Louis et al. (2010) e de Moore e Shaw (2017) e a tese de Rhoads (2019).

O relatório de 2002 da Associação Americana dos Administradores Escolares, denominado Using Data to Improve Schools: What's Working, é um guia sobre como usar dados para impulsionar a melhoria escolar e é voltado para os líderes do sistema escolar e suas equipes, na medida em que tem como objetivo construir uma cultura distrital de investigação que valoriza o uso de dados para tomadas de decisão. O relatório apresenta a importância do uso de dados para pensar ações no âmbito dos distritos e das escolas, bem como aponta caminhos sobre como fazer uso dos dados semelhantes àqueles que apresentamos no levantamento bibliográfico no capítulo inicial da tese. Todavia, não foram explicitadas possíveis razões que justificassem a dificuldade em se fazer uso dos dados. A única menção à palavra confiabilidade estava relacionada à consistência das pontuações dos testes em diferentes administrações deste, ou seja, a confiabilidade como resposta à pergunta "qual a probabilidade de um aluno obter a mesma pontuação se fizesse o mesmo teste uma segunda vez?".

O relatório de Louis et al. (2010) apresenta um compilado de pesquisas sobre liderança, melhora no desempenho dos estudantes e uso 
de dados. Busca, portanto, enfatizar a influência da liderança na construção de hábitos de uso de dados para pensar processos e tomar decisões. $O$ relatório foi dividido em três partes, sendo a primeira pautada por discussões acerca das ações dos líderes na escola para melhorar o desempenho dos estudantes, a segunda sobre os distritos e seus líderes e como promovem a melhoria da escola e o aprendizado dos alunos e, por fim, a terceira parte foi sobre a liderança estadual e o relacionamento com distritos. Em todas elas foram destacadas aspectos relativos à importância da liderança como promotora de uma cultura de uso de dados e sobre sua influência indireta no aprendizado dos estudantes, corroborando os argumentos já apresentados nesta tese sobre a relação entre a liderança e o uso de dados. O relatório também tece considerações sobre as limitações para o uso de dados nos distritos e nas escolas a partir de três categorias: amplitude dos dados, natureza dos dados (formal ou informal) e padrões de uso dos dados. Na primeira categoria, assim como argumentamos, o relatório afirma que a amplitude dos dados usados pelos diretores é determinada pelos seus pensamentos, valores e sentimentos e que as práticas de uso dos dados têm antecedentes que são as próprias experiências passadas, conhecimentos e crenças dos diretores, bem como suas interpretações das consequências de suas práticas atuais para os contextos locais e mais amplos em que se encontram.

$\mathrm{Na}$ categoria sobre a natureza dos dados (informal ou formal) Louis et al. (2010) apontam que não podemos afirmar que as decisões na escola não sejam baseadas em dados, pois elas são baseadas em dados. $O$ questionamento, na verdade, deve estar relacionado com a natureza do dado porque, frequentemente, as decisões são baseadas nas impressões sobre a "prática comum no local de trabalho"; esses relatos, tipicamente narrativos de experiência, constituem uma característica difundida no discurso no local de trabalho e um recurso para a aprendizagem no local de trabalho. Por último, na categoria padrões de uso dos dados, os autores afirmam que, apesar dos mesmos tipos de dados serem disponibilizados para todas as escolas como, rendimento e desempenho dos alunos, não há um padrão único de uso em função das outras duas categorias explicadas anteriormente. 
Como conclusão os autores afirmam que há uma variabilidade na forma em que distritos e escolas confiam nos instrumentos de diagnóstico e avaliação formativa do estado ou instrumentos desenvolvidos pelo distrito e que isso, consequentemente, modifica as práticas de uso dos dados. Além disso, mencionam a auto eficácia dos professores e gestores em relação aos dados como fator relevante para o uso instrucional dos mesmos.

A pesquisa de Moore e Shaw (2017) teve como objetivo verificar a percepção dos diretores escolares acerca das suas crenças, atitudes e ações relacionadas ao uso de dados provenientes das avaliações estadual e distrital. A pesquisa foi feita a partir da aplicação de questionários para todos os 406 diretores das 147 escolas distritais do centro-oeste dos Estados Unidos. Os resultados apontam que, em média, os diretores estão no cargo há 12 anos, usam os dados de 2 a 3 vezes ao ano e o fazem, majoritariamente, para monitorar as práticas instrucionais na escola. Os dados são pouco utilizados como ferramenta de conhecimento do contexto familiar e para pensar processos comunicativos com as famílias e a comunidade escolar. Além disso, os autores afirmam que quanto mais confiantes em relação a própria habilidade de usar os dados, mais os diretores usam os dados. Em relação às crenças sobre os testes externos, de uma maneira geral, os diretores acreditam que a avaliação do distrito mensura melhor o aprendizado, o acesso aos seus dados é melhor e eles são mais fáceis de interpretar. Apontam, ainda, que o desenvolvimento profissional dos diretores é um elemento chave para o processo de interpretação dos dados, mas que esta formação se relaciona mais com a interpretação de dados sobre o desempenho dos estudantes do que com o uso de múltiplas medidas para pensar processos na escola. Por fim, Moore e Shaw (2017) identificaram oito barreiras para a tomada de decisão baseada em dados, a saber: suporte do distrito para uso dos dados; os sistemas de dados; políticas que promovam acesso direto dos funcionários aos vários tipos de dados; preparação dos funcionários para uso de dados; habilidades técnicas dos funcionários para usar e acessar os sistemas; comunicação e compartilhamento de informações entre os departamentos 
do distrito; e tempo para que os funcionários conduzam atividades que fomentem a tomada de decisão baseada em dados.

A pesquisa de Rhoads (2019) tinha como objetivo entender a eficácia de liderança educacional e sua relação com o uso de dados e com a confiança no uso de dados. Para tanto, fez uma pesquisa quali-quanti com 111 gestores do distrito da Califórnia. Da mesma forma que Moore e Shaw (2017), o autor encontrou que a formação para uso de dados, o tempo disponível para usar os dados e a manutenção dos sistemas para uso dos dados são impeditivos para que as escolas consigam construir uma cultura de uso de dados para tomada de decisão. No que diz respeito à confiança, esta estava atrelada a capacidade do diretor em usar dados, ou seja, no quanto ele se achava competente em usar os dados (auto-eficácia).

Podemos concluir a partir destas pesquisas que, no que diz respeito à confiança, elas versam fundamentalmente sobre a autoeficácia dos gestores como fator propulsor para o uso de dados e, portanto, assumem uma perspectiva diferente da que aqui apresentamos. Ainda assim, parece possível uma interlocução com a literatura nacional sobre a auto eficácia do diretor e sobre este conceito não aplicado apenas a sua relação com o uso dos dados, mas também no que se refere a crença na própria capacidade de tomar e implementar decisões instrucionais a partir dos dados ou até mesmo sobre a relevância destas frente à sua visão sobre o papel da escola na sociedade em geral e para os usuários da escola que dirigem em particular. 


\section{7 \\ Considerações Finais}

$\mathrm{Na}$ tentativa de responder à questão de pesquisa desta tese, qual seja, quais fatores influenciam os processos de uso de dados pedagógicos e administrativos na gestão das escolas realizamos, inicialmente, um levantamento bibliográfico para situar a discussão sobre uso de dados e gestão escolar. Durante este processo foi possível mapear na literatura sete fatores que interferem no uso de dados nos contextos escolares e, a partir deles, resolvemos traçar os caminhos teóricos deste estudo. Por conta disso, em cada um dos capítulos da tese buscamos discutir um fator ou um conjunto deles com o intuito de compreender em que medida eles se faziam relevantes dentro do contexto da pesquisa. O contexto da pesquisa se deu na rede estadual de educação de Minas Gerais, mais especificamente, em duas escolas da SRE de Juiz de Fora. Nas duas escolas foram feitas observações de campo e entrevistas com os membros da equipe gestora.

No momento em que discutimos e analisamos o contexto organizacional, os sistemas de gestão e o acesso e suporte à tecnologia e a formação para uso dos dados da rede estadual de educação mineira vimos que esta possui sistemas de avaliação e de gestão desde 1992 e 2008, respectivamente. Ou seja, esses sistemas não só existem há um bom tempo como a SRE de Juiz de Fora tem, em sua estrutura organizacional, uma diretoria responsável para dar suporte tecnológico e operacional para as escolas em relação a tais sistemas. Além disso, desde 2016 que a SEE/MG implementa políticas cujo foco é o uso de dados para se pensar processos e ações nas escolas e fomentar tomadas de decisões com base nas análises de dados dos estudantes.

Por conta disso, teoricamente, as escolas estariam contempladas em relação aos fatores relativos à existência de sistemas de gestão e ao acesso e suporte à tecnologia para uso dos mesmos, além da oferta de formação para uso dos dados via políticas públicas para os diretores. Porém, isso não é suficiente para garantir que o uso de dados para fins pedagógicos se efetive nas escolas, pois conforme aponta Farrel (2015) é 
preciso analisar a relação entre o contexto macro (SEE e SRE) e o contexto micro (escola). Diante disso, buscamos compreender em que medida os fatores mencionados eram operacionalizados em cada uma das escolas. Após as análises, chegamos à conclusão de que, mesmo com uma rede de apoio da SRE de Juiz de Fora, as escolas enfrentam dificuldades para fazer uso dos dados e, além disso, há outros fatores, principalmente relacionados aos diretores escolares, que são chaves no processo de uso de dados nas escolas, qual seja: a racionalidade burocrática.

O fator racionalidade burocrática opera tanto pela via formal da instituição quanto pela via subjetiva dos diretores. Sendo assim, o modo como a racionalidade institucional reverbera nas instituições escolares, via políticas públicas, pode conformar práticas nas escolas. Ao mesmo tempo, vimos que o diretor mescla diferentes tipos de ações racionais a depender das circunstâncias com as quais eles precisam lidar. Tal discussão se mostrou ainda mais relevante na medida em que o diretor escolar é um burocrata híbrido e esta posição na burocracia the confere poder, já que permite que ele faça negociações, gerencie conexões e interfira em fluxos de informação. Sendo assim, fazer uso desta categoria para compreender a atitude dos gestores escolares frente aos dados é uma contribuição para as pesquisas no campo da Educação.

As observações do cotidiano das escolas e as entrevistas realizadas nos permitem afirmar que as práticas de uso de dados dos diretores escolares tendem a seguir uma linha operacional burocrática. Isso significa dizer que as escolas cumprem os protocolos das políticas públicas, mas ainda não construíram uma cultura escolar para o uso de dados. Para que esta cultura seja construída verificamos que outros dois fatores são cruciais neste processo e, por isso, se inter-relacionam, quais sejam: a liderança do diretor e o clima escolar.

Pensar sobre liderança do diretor significa também refletir sobre o clima escolar visto que a liderança interfere nas práticas cotidianas da escola e nos modos de relacionamento entre as pessoas, ou seja, está intrinsecamente relacionada ao clima escolar e vice-versa. Sobre o primeiro aspecto percebemos que os diretores, apesar de serem reconhecidamente 
lideranças nas escolas e exercerem uma liderança distribuída, tem diferentes modos de operacionalizá-las, diferentes estilos de gestão (Paes de Carvalho \& Canedo, 2011). Tal fato consequentemente reverbera no clima da escola dado que as relações entre os sujeitos das escolas são construídas de formas diferentes e que o contexto socioespacial onde as escolas estão também são distintos. Ademais, a visão de escola que cada um dos diretores possui faz com que as prioridades de cada instituição escolar sejam diferentes. Na escola Travessia, notadamente, a prioridade da equipe gestora se aproximava de um assistencialismo para que os alunos permanecessem na escola e não fossem trabalhar no tráfico de drogas. Todavia, focar em somente uma das variáveis envolvidas no processo de ensino e aprendizagem (permanência na escola) e desconsiderar o fator aprendizagem, por exemplo, pouco ou nada contribuirá para que 0 estudante tenha melhores possibilidades profissionais futuras. Na escola Jardim Botânico, em contrapartida, a visão de escola que se tinha era focada na permanência e no aprendizado e, por conta disso, o diretor investia na infraestrutura da instituição escolar, monitorava o aprendizado dos estudantes via sistemas de gestão e avaliação e também através das reuniões com os demais membros da equipe gestora. Sendo assim, ao seu modo e mesmo que ainda pouco independente, já que o uso pedagógico dos dados estava atrelado às políticas da SEE/MG, a equipe gestora fazia algum uso dos dados nas escolas.

Após todos os processos de análise desenvolvidos durante a pesquisa e, a partir da experiência profissional da pesquisadora que atua, desde 2013, em um programa de mestrado profissional e orienta gestores educacionais de várias regiões do Brasil a desenvolverem estudos de caso, principalmente, sobre temáticas de avaliação educacional, políticas públicas e gestão escolar, apresentamos um novo fator que tem potencial interferência no uso de dados para fins pedagógicos na escola: a confiança. Com o intuito de compreender em que medida a literatura educacional trabalhava esse tema relacionado ao uso de dados, fizemos um levantamento que mostrou que as pesquisas sobre confiança estavam atreladas à discussão sobre autoconfiança e autoeficácia dos diretores 
educacionais para usar os dados, ou seja, o quanto os diretores se sentem capazes em usar os dados disponíveis nos sistemas de gestão e avaliação das redes educacionais e, a partir deles, tomar decisões. Frente a isso, constatamos que as pesquisas utilizam uma perspectiva diferente da que propomos, qual seja, a confiança atrelada à confiabilidade do diretor nos dados provenientes dos sistemas mineiros de avaliação e gestão e a identificação, ou seja, em que medida os diretores identificam ou não as escolas nos dados provenientes do sistema. A partir desta reflexão esperamos contribuir para ampliar a percepção sobre a confiança e a sua relação com o uso de dados, ou seja, a confiança como uma categoria relacionada ao quanto os diretores, ao identificarem as escolas nos dados, confiam neles e os utilizam para tomar decisões.

A partir de todo o exposto acreditamos que cumprimos com os objetivos desta pesquisa e abrimos outros caminhos de pesquisas possíveis. 


\section{8 \\ Referências bibliográficas}

AFONSO, Almerindo Janela. Avaliação educacional: regulação e emancipação. São Paulo: Cortez, 2000.

ALVERSON, Charlotte; YAMAMOTO, Scott. Educational Decision making with visual data and graphical interpretation: assessing the effects os user preference and accuracy. SAGE Open, 2016.

ANTUNES, Ana Lúcia. Avaliação da $8^{\mathrm{a}}$ série do ensino fundamental em Minas Gerais. In: A Avaliação da Educação Básica: a experiência brasileira. Orgs.: Brooke, Nigel; Alves, Maria Teresa Gonzaga; Oliveira, Lina Kátia Mesquita. Belo Horizonte, Minas Gerais: Fino Traço, 2015

BAUER, Adriana. Usos dos resultados das avaliações de sistemas educacionais: iniciativas em curso em alguns países da América. R. bras. Est. pedag., Brasília, v. 91, n. 228, p. 315-344, maio/ago. 2010.

BONAMINO, Alícia. Tempos de avaliação educacional: o SAEB, seus agentes, referências e tendências. Rio de Janeiro: Quartet,2002.

BONAMINO, Alícia; SOUSA, Sandra Zákia. Três gerações de avaliação da educação básica no Brasil: interfaces com o currículo da/na escola. Educação e Pesquisa, São Paulo, v. 38, n. 2, p. 373-388, abr./jun. 2012.

BRESSER-PEREIRA, Luiz Carlos. Da administração pública burocrática à gerencial. Revista do Serviço Público, v. 47, n. 1, 1996

BRESSER-PEREIRA, Luiz Carlos. A reforma gerencial do Estado de 1995. Revista de Administração Pública. Rio de Janeiro, v. 34, n. 4, p. 7-26, jul./ago. 2000.

Disponível em:<http://bibliotecadigital.fgv.br/ojs/index.php/rap/article/view/6289/4880> . Acesso em: 05 nov. 2018.

BRESSER-PEREIRA, Luiz Carlos. Construindo o Estado republicano: democracia e reforma da gestão pública. Rio de Janeiro: Editora FGV, 2009.

BRESSER-PEREIRA, Luiz Carlos. Reforma Gerencial e legitimação do estado social. Revista de Administração Pública. Rio de Janeiro, v. 51, n. $1, \quad$ p. 147-156, 2017.2 Disponível em:<http://www.scielo.br/pdf/rap/v51n1/0034-7612-rap-51-01-00147.pdf>. Acesso em: 05 nov. 2018.

CAVALCANTE, Pedro Luiz; LOTTA, Gabriela Spanghero. Burocracia de Médio Escalão: perfil, trajetória e atuação. Brasília: ENAP, 2015.

CAVALCANTI, Sérgio; LOTTA, Gabriela S.; PIRES, Roberto Rocha C. Contribuições dos estudos sobre burocracia de nível de rua. In: Burocracia 
e políticas públicas no Brasil: interseções analíticas. (Org.) PIRES, R.; OLIVEIRA, V. Brasília: Ipea: Enap, 2018

CERDEIRA, Diana; PRADO, Ana Pires do; ROSISTOLATO, Rodrigo; TAVARES, Mayara; COSTA, Marcio. Conhecimento e uso de indicadores educacionais no município do Rio De Janeiro. Est. Aval. Educ., São Paulo, v. 28, n. 69 , p. 926-968, set./dez. 2017.

CERDEIRA, Diana. Fatores associados ao uso dos resultados de avaliações

externas no contexto das políticas de responsabilização educacional. RBPAE, v. 34, n. 2, p. 613 - 634, 2018.

CRUZ, Larissa Frossard Rangel Avaliação externa e qualidade de ensino: apropriações e usos dos dados em escolas públicas municipais em Macaé/RJ. Tese (doutorado)-Pontifícia Universidade Católica do Rio de Janeiro, Departamento de Educação, 2014.

DIAS, Rafaela Cyrino Peralva. Resenha: modernidade e identidade. Psicol. Soc., Porto Alegre, v. 17, n. 3, p. 87-88, 2005.

FARRELL, Caitlin. Designing School Systems to Encourage Data Use and Instructional Improvement: A Comparison of School Districts and Charter Management Organizations. Educational Administration Quarterlv. 51, n. 3, 2015.

FONSECA, Gilson Luiz Bretas. Qualidade dos Indicadores Educacionais para avaliação de escolas e redes públicas de ensino básico no Brasil. 2010. Disponível em: https://repositorio.ufjf.br/jspui/bitstream/ufj/2686/1/gilsonluizbretasdafonse ca.pdf. Acesso em 20 mar. 2020.

FONTANIVE, Nilma Santos. A Divulgação dos Resultados das Avaliações dos Sistemas Escolares: limitações e Perspectivas. Ensaio, v. 21, n. 78, 2013.

FREITAS, Dirce Nei Teixeira de; OVANDO, Nataly Gomes. A avaliação educacional em contextos municipais. Educ. Soc., Campinas, v. 36, n. 133, p. 963-984, 2015.

FREITAS, Ramon dos Reis. Protocolos de Gestão no contexto escolar: o uso de ferramentas para apropriação de resultados das avaliações externas. 2017. Dissertação (Mestrado Profissional em Gestão e Avaliação da Educação Pública) - Faculdade de Educação/CAEd, Universidade Federal de Juiz de Fora, Juiz de Fora, 2017.

GALWAY, Gerald; SHEPPARD, Bruce. Research and evidence in education decision-making: A comparison of results from two pan-Canadian studies. Education Policy Analysis Archives, v. 23, n.109, 2015. 
GIDDENS, Anthony. As consequências da modernidade. São Paulo: Editora UNESP, 1991.

GIDDENS, Anthony. Conceitos essenciais de sociologia. .São Paulo: Editora UNESP, 2017.

HALVERSON, Richard. Data-driven leandership for learning in the age of accountability. In: BOWERS, Alex; SHOHO, Alan; BARNETT, Bruce. Using Data in Schools to Inform Leadership and Decision Making. Vol. 5. International Research on School Leadership. 2014.

HOWLETT, M. Public managers as the missing variable in policy studies: an empirical investigation using canadian data. Review of Policy Research, v. 28, no 3, p. 247-63, May 2011.

INSTITUTO UNIBANCO. Relatório de atividades Jovem de Futuro. 2019. Disponível em: https://www.institutounibanco.org.br/wpcontent/uploads/2020/06/IU-Relatorio_Atividades_MG_2019-digital.pdf.

Acesso em: 25 nov. 2020.

KLAR, Hans; BREWER, Curtis. Successful Leadership in High-Needs Schools:

An Examination of Core Leadership Practices Enacted in Challenging Context. Educational Administration Quarterly, v. 49, n. 5, 2013.

LASATER, Kara; ALBILADI, Waheeb; DAVIS, William; BENGTSON, Ed. The Data Culture Continuum: An Examination of School Data Cultures. Educational Administration Quarterly, 2019.

LEITHWOOD, Kenneth; JANTZI, Doris. Transformational School Leadership Effects: A Replication. School Effectiveness and School Improvement, v.10, № 4, p. 451-479, 1999.

LEITHWOOD, Kenneth. ¿Cómo liderar nuestras escuelas? Aportes desde la investigación. Santiago: Salesianos Impresores, 2009.

LEITHWOOD, Kenneth; SUN, Jingping; SCHUMACKER, Randall. How School Leadership

Influences Student Learning: A Test of "The Four Paths Model". Educational Administration Quarterly, 2019.

LEITHWOOD, Kenneth; HARRIS, Alma; HOPKINS, David. Seven strong claims

about successful school leadership revisited. School Leadership \&

Management, v. 40, n. 1, 2020.

LIMA, Licínio. A escola como organização educativa: uma abordagem sociológica. Cortez Editora, 2003. 
LIMA, Naira da Costa Muylaert. Diretores escolares: burocratas de nível de rua ou médio escalão?. Revista Contemporânea de Educação, v. 14, n. 31, set/dez. 2019.

LIPSKY, Michael. Street-level bureaucracy: dilemas of the individual in Public Services. Russell Sage Foudation, New York, 2010.

LIPSKY, Michael. Burocracia de nível de rua: dilemas do indivíduo nos serviços públicos. Brasília: Enap, 2019. Disponível em: https://repositorio.enap.gov.br/bitstream/1/4158/1/Burocracia\%20de\%20n \%c3\%advel\%20de\%20rua_Michael\%20Lipsky.pdf. Acesso em: $15 \mathrm{dez}$. 2020.

LITTLE, Michael, SADLER, Lora; MERRILL, Becca. Data-driven decision making in early education: Evidence From North Carolina's Pre-K program. Education Policy Analysis Archives, v. 27, n. 18, 2019.

LOTTA, Gabriela Spanghero; PIRES, Roberto Rocha Coelho; OLIVEIRA, Vanessa Elias. Burocratas de médio escalão: novos olhares sobre velhos atores da produção de políticas públicas. Revista do Serviço Público Brasília, v.65, n. 4, p. 463-492, out/dez 2014.

LOTTA, Gabriela Spanghero. Agentes de implementação: uma forma de análise de políticas públicas. Cadernos de Gestão Pública e Cidadania, v. 19, n. $65,2014$.

LOTTA, Gabriela Spanghero; Santiago, Ariadne. Autonomia e discricionariedade: matizando conceitos-chave para o estudo de burocracia. BIB, São Paulo, n. 83, 2017.

MACHADO, Cristiane; ALAVARSE, Ocimar Munhoz. Qualidade das escolas: tensões e potencialidades das avaliações externas. Educ. Real., Porto Alegre, v. 39, n. 2, p. 413-436, 2014.

MANDINACH, Ellen B.; SCHILDKAMP, Ki., Misconceptions about databased decision making in education: An exploration of the literature. Studies in Educational Evaluation. Available online 23 January 2020.Disponível em: https://doi.org/10.1016/j.stueduc.2020.100842.

Mandinach, Ellen. B.; Gummer, E. S. Data literacy for educators: Making it count in teacher preparation and practice. (2016). New York, NY: Teachers College Press.

MARSH, Julie. Interventions Promoting Educators' Use of Data: Research Insights and Gaps. Teachers College Record, v.14, n. 11, 2012.

MINAS GERAIS. Secretaria de Estado de Educação. Resolução no 457, de 20 de setembro de 2009. Dispõe sobre a inspeção escolar na educação básica no sistema estadual de ensino de Minas Gerais. Disponível em: https://cee.educacao.mg.gov.br/index.php/legislacao/resolucoes/send/47- 
2009/12963-resolucao-cee-n-457-de-30-de-setembro-de-2009. Acesso em: $\quad 19 \quad$ dez. 2020.

MINAS GERAIS. Resolução SEE $n^{\circ}$ 1.180, de 28 agosto de 2008. Estabelece as diretrizes e dá orientações para implantação, manutenção e atualização de dados do Sistema Mineiro de Administração Escolar. Disponível em: https://www2.educacao.mg.gov.br/images/documentos/1180_r.pdf. Acesso em: 05 nov. 2018.

MINAS GERAIS. Resolução no 457 de 30 de setembro de 2009. Disponível em: https://cee.educacao.mg.gov.br/index.php/legislacao/resolucoes/send/472009/12963-resolucao-cee-n-457-de-30-de-setembro-de-2009. Acesso em: 20 out. 2020.

MINAS GERAIS. Secretaria de Estado de Educação. Edital SEPLAG/SEE no. 01 /2011, de 11 de julho de 2011. Disponível em: https://www.concursosnobrasil.com.br/concursos/edital/edital-educacaomg.html. Acesso em: 22 set. 2020.

MINAS GERAIS. Secretaria de Estado de Educação. Manual do PAAE Maria Inez Barros Simões... [et al.]. Belo Horizonte: Instituto Avaliar, 2013. Disponível em:

http://paae.institutoavaliar.org.br/sistema_ava_v2/default.aspx?id_objeto= 323389\&id_pai=23967\&area=atributo. Acesso em: 10 out. 2018.

MINAS GERAIS. Governo do Estado. Resolução 3.428, de 13 de junho de 2017a. Estabelece normas para organização e atuação do Serviço de Inspeção Escolar nas unidades regionais e escolares da Secretaria de Estado de Educação de Minas Gerais. Disponível em: https://www2.educacao.mg.gov.br/images/documentos/3428-17-r.pdf.

Acesso em: 23 ago. 2020.

MINAS GERAIS. Governo do Estado. Edital SEE no. 07/2017, de 27 de dezembro de 2017. Concurso público para provimento de cargos das carreiras de especialista em educação básica e professor de educação básica do quadro de pessoal da secretaria de estado de educação. Disponível em: http://www.fumarc.com.br/imgDB/concursos/Edital\%20SEE\%20n-072017\%20-\%20FUMARC-20171228-132936.pdf. Acesso em: 10 fev. 2021.

MINAS GERAIS. Secretaria de Estado de Educação. Guia do Especialista em Educação Básica. [2018]. Disponível em: https://srefabricianodivep.files.wordpress.com/2018/07/guiaespecialista.pdf. Acesso em: 19 dez. 2020.

MINAS GERAIS. Secretaria de Estado de Educação. Mapa das Superintendências Regionais de Ensino. 2019a. Disponível em: 
https://www2.educacao.mg.gov.br/images/stories/2019/Mapa_SREs_indic _porte_2019.png. Acesso em: 04 fev. 2021.

MINAS GERAIS. Secretaria de Estado de Educação. Transforma Minas: programa de gestão de pessoas por mérito e competência. 2019b. Disponível em: https://www.mg.gov.br/sites/default/files/transforma_minas/arquivos/descri cao___superintendente_regional_de_ensino_-_link_atualizado.pdf. Acesso em: 04 fev. 2021.

MINAS GERAIS. Secretaria de Estado de Educação. Etapas do Processo de seleção profissional para o cargo de Superintendente. [2019c]. Disponível em: https://www.mg.gov.br/conteudo/transforma-minas/etapasdo-processo. Acesso em: 04 fev. 2021.

MINAS GERAIS. Secretaria de Estado de Educação. Processo de Escolha de Diretor e vice-diretor de escola estadual de Minas Gerais. Manual de Orientação, 2019.

MINAS GERAIS. Secretaria de Estado de Educação. Edital SEE no 02/2020. Certificação ocupacional de diretor de escola estadual. Disponível em:

http://www.institutoavaliar.org.br/certificacao2020/banco_objetos/edital_20 20.pdf. Acesso em: 19 dez. 2020.

MINAS GERAIS. Secretaria de Estado de Educação. Serviço de Inspeção Escolar. [2021]. Disponível em: https://drive.google.com/file/d/1g3GzX23wQ178KNj5BTsHhSAxhvXFL3_/view. Acesso em: 23 nov. 2020.

MOTA, Maria Océlia. Entre a meritocracia e a equidade: o prêmio escola nota dez na percepção e atuação dos agentes implementadores. 2018. 297 fls. Tese (Doutorado em educação) - Pontifícia Universidade Católica do Rio de Janeiro, Rio de Janeiro, RJ, Brasil, 2018.

NOVATO, Valéria de Oliveira Lemos; NAJBERG, Estela; LOTTA, Gabriela Spanghero. O burocrata de médio escalão na implementação de políticas públicas. Revista de Administração Pública. Rio de Janeiro, v. 53, n. 3, p. 416-432, 2020.

NUÑEZ, Carolina Portela; Koslinski, Mariane Campelo; Fernández, Silvina Júlia. Políticas de incentivo ao uso de dados educacionais: experiências no contexto internacional e brasileiro. Jornal de Políticas Educacionais, v. 13, n. 17, 2019.

OLIVEIRA, Vanessa Elias.; ABRUCIO, Fernando Luiz. Entre a política e a burocracia: a importância dos burocratas de nível médio para a produção de políticas públicas em saúde e educação. Artigo apresentado no 35을 ENCONTRO ANUAL DA ANPOCS, Caxambu, MG, 2011. 
OLIVEIRA, Ana Cristina Prado de. As relações entre direção, liderança e clima escolar em escolas municipais do Rio de Janeiro. Tese (doutorado)Pontifícia Universidade Católica do Rio de Janeiro, Departamento de Educação, 2015.

OLIVEIRA, Ana Cristina Prado de; WALDHELM, Andrea Paula Souza.

Liderança do diretor, clima escolar e desempenho dos alunos: qual a relação?

Ensaio: Avaliação e Políticas Públicas em Educação, v. 24, n. 93, 2016

OLIVEIRA, Marina. Correção de fluxo em uma escola da rede pública municipal do Rio de Janeiro: percepções e discricionariedade dos agentes implementadores. 2017. 199 fls. Dissertação (Mestrado em educação) Pontifícia Universidade Católica do Rio de Janeiro, Rio de Janeiro, RJ, Brasil, 2017

OLIVEIRA, Vanessa Elias.; ABRUCIO, Fernando Luiz. Burocracia de Médio Escalão e diretores de escola: um novo olhar sobre o conceito. In: Burocracia e políticas públicas no Brasil: interseções analíticas. (Org.) PIRES, R.; OLIVEIRA, V. Brasília: Ipea: Enap, 2018

OLIVEIRA, Ana Cristina Prado de; PAES DE CARVALHO, Cynthia. Gestão escolar, liderança do diretor e resultados educacionais no Brasil. Revista Brasileira de Educação, v. 23, 2018.

PAES DE CARVALHO, Cynthia., BONAMINO, Alícia., KAPPEL, D. Redes Municipais de Ensino, Planejamento e Resultados Educacionais. Arquivos Analíticos de Políticas Educativas, v. 19, n. 30, 2011.

PAES DE CARVALHO, Cynthia. Gestão, autonomia e liderança na escola: alguns conceitos e desafios atuais. Coleção Gestão e Avaliação da Educação Pública - Volume III - Gestão do Currículo e Gestão e Liderança - 2012 - pp. 77-95.

PAES DE CARVALHO, Cynthia; CANEDO, Maria Luiza. Estilos de gestão, cultura organizacional e qualidade de ensino. Revista Educação e Cultura Contemporânea, v. 9, n. 19, 2011.

PARK, V., DALY, A. J., GUERRA, A. W. (2013). Strategic Framing: How Leaders Craft the Meaning of Data Use for Equity and Learning. Educational Policy, v. 27, n. 4, 2012.

PARK, Vicki. Leading Data Conversation Moves: Toward Data-Informed Leadership for Equity and Learning. Educational Administration Quarterly, v. 54, n. $4,2018$.

PIRES, R. Efetividade das instituições participativas no Brasil: estratégias de avaliação. Brasília: Ipea. 2011. 
PIRES, Roberto. O trabalho da burocracia de médio escalão e sua influência nas políticas públicas. In: Burocracia e políticas públicas no Brasil: interseções analíticas. (Org.) PIRES, R.; OLIVEIRA, V. Brasília: Ipea: Enap, 2018

PITON, Nayhalia; MACHADO, Cristiane. Clima escolar: mapeamento e análise de artigos científicos constantes no portal de periódicos CAPES. Revista @mbienteeducação. São Paulo: Universidade Cidade de São Paulo, v. 12, n. 1, 2019.

PRADO, Mauricio Almeida. O Processo de Implementação de Reformas Gerenciais na Educação Básica: São Paulo (2007-2010) e Minas Gerais (2004-2010) em Perspectiva Comparada / Mauricio Almeida Prado. - 2012. 355 f. Orientador: Regina Silvia Viotto Monteiro Pacheco Tese (doutorado) - Escola de Administração de Empresas de São Paulo.

PROTES, Mariana Aguiar de Carvalho. 0 uso de dados do Simave na Superintendência Regional de Manhuaçu - MG: desafios e possibilidades. 2020. Dissertação (Mestrado Profissional em Gestão e Avaliação da Educação Pública) - Faculdade de Educação/CAEd, Universidade Federal de Juiz de Fora, Juiz de Fora, 2020.

QUEIROZ, Emerson Marques. A utilização do Programa de Avaliação da Aprendizagem Escolar (PAAE) nas escolas estaduais de Passos: reflexões sobre avaliação diagnóstica do Ensino Médio. Dissertação (mestrado profissional) - Universidade Federal de Juiz de Fora, Faculdade de Educação/CAEd. Programa de Pós-Graduação em Gestão e Avaliação da Educação Pública, 2015.

RIBEIRO, Vanda Mendes; GUSMAO, Joana Borges Buarque de. Uma leitura dos usos dos indicadores da qualidade na educação. Cad. Pesqui., São Paulo, v. 40, n. 141, 2010.

ROEGMAN, Rachel; PERKINS-WILLIAMS, Ruqayyah; MAEDA, Yukiko; GREENAN, Kathleen A. Developing Data Leadership: Contextual Influences on Administrators' Data Use. Journal of Research on Leadership Education, 2017.

ROEGMAN, Rachel; KENNEY, Rachael; MAEDA, Yukiko; JOHNS, Gary. When Data-Driven Decision Making Becomes Data-Driven Test Taking: A Case Study of a Midwestern High School. Educational Policy, v. 1, n. 31, 2019.

ROSISTOLATO, Rodrigo; VIANA, Guilherme Os gestores educacionais e a recepção dos sistemas externos de avaliação no cotidiano escolar. Educ. Pesqui., v.40, n.1, 2014.

SILVA, Jerônimo Jorge Cavalcante. Gestão escolar participada e clima organizacional. Gestão em Ação, Salvador, v.4, n.2, p.49-59, jul./dez.2001. 
SILVA, Vandré Gomes da. Usos de avaliações em larga escala em âmbito escolar. 36 reunão ANPED. Anais..., 2013. Disponível em: http://36reuniao.anped.org.br/pdfs_trabalhos_aprovados/gt14_trabalhos_p dfs/gt14_3264_texto.pdf. Acesso em: 10 jan. 2021.

SOUSA, Sandra Zákia; OLIVEIRA, Romualdo Portela de Sistemas estaduais de avaliação: uso dos resultados, implicações e tendências. Cad. Pesqui., Dez 2010, vol.40, no.141, p.793-822

SUPOVITZ, Jonathan; MISHOOK, Ellen. In Search of Leading Indicators in Education. Education Policy Analysis Archives, v. 20, n. 19, 2012

TEIXEIRA, Bestriz Basto; PAES DE CARVALHO, Cynthia; OLIVEIRA, Ana Cristina Prado de; LESSA, Paula Batista. Diretores e currículo unificado: uma pesquisa em Minas Gerais. In: Tufi Machado Soares; Alícia Bonamino. (Org.). Estudos sobre a educação brasileira: múltiplos olhares. 1ed.Rio de Janeiro: Editora da PUC, 2017, v. 1, p. 1-22.

VANDENBERGHE, Frédéric. Uma história filosófica da sociologia alemã: alienação e reificação. Volume 1: Marx, Simmel, Weber e Lukács. São Paulo: Annablume, 2012.

VIDAL; Eloisa; LERCHE, Sofia. Gestão Educacional e resultados no IDEBum estudo de caso em dez municípios Cearenses. Est. Aval. Educ., São Paulo, v. 22, n. 50, 2011.

VILARDI; Luísa; PAES DE CARVALHO, Cynthia. Diretores escolares e o uso dos

dados do Simade em escolas da rede estadual de educação de Minas Gerais. Revista Contemporânea de Educação, v. 14, n. 31, set/dez. 2019.

WAYMAN, J.C.; CHO, V.; JIMERSON, J.B.; SPIKES, D.D. District wide effects on data use in the classroom. Educationa Policy Analysis

Archives, v. 20, n. 25.

WEBER, Max. A ética protestante e o espírito do capitalismo. Tradução: José Marcos Mariani de Macedo. São Paulo: Companhia das Letras, 2004.

YIN, R. K. Estudo de caso: planejamento e métodos. 2. ed. Porto Alegre: Bookman, 2001. 


\section{APÊNDICE A - Roteiro de entrevista para equipe gestora}

\section{$\checkmark$ Entregar TCLE}

$\checkmark$ Apresentação da entrevistadora e da pesquisa

$\checkmark$ Pedir para o entrevistado/a se apresentar e dizer sobre:

\section{Características sócio demográficas}

Sexo

Idade;

Mês/Ano de nascimento:

Formação acadêmica: Curso Superior/IES

Pós-Graduação (tipo e área):

Formação Específica em gestão escolar:

Número de anos como diretor escolar:

Número de anos como diretor nesta escola:

Ocupou algum cargo na gestão escolar antes de ser diretor?

Experiência profissional fora do campo educacional

BLOCO 1 - Informações sobre a gestão escolar (Tipologia de gestão)

1. cotidiano na escola - Como você organiza seu cotidiano na escola? $O$ que

demanda mais o seu tempo?

2. atividade que demanda mais tempo - $\mathrm{O}$ que vc acha mais importante fazer

como diretor? é nisso que gasta mais tempo?

\section{3. importância}

\section{BLOCO 2 - SIMADE e SIMAVE}

1. Explicar o uso do SIMADE/ SIMAVE na sua escola.

2. Alguém fez curso?

3. é vc que mexe?

4. Com que frequência vcs usam? (internet)

5. Quais são os relatórios que vc tira do SIMADE/ SIMAVE?

Exemplifique. O que $v c$ faz com isso? Porque?

6. Quais dados são mais usados? Porque?

7. O que o SIMADE/ SIMAVE oferece é suficiente para gestão da escola? Porque?

(sugestões para melhorar?)

8. Que tipo de informações do SIMADE/ SIMAVE você utiliza para tomar decisões na sua

escola? Exemplifique. OU vc pode exemplificar alguma recente tomada de decisão a partir dos dados

9. a SRE oferece algum suporte para o uso dos dados? 


\section{APÊNDICE B - Fotos da escola Travessia}

A escola Travessia possui uma construção com dois pavimentos, sendo que, no primeiro, fica a sala da diretora, a sala dos professores, os banheiros, a cozinha e o refeitório; no segundo, além das salas de aula, estão a biblioteca, a sala de vídeo, a brinquedoteca e os banheiros, conforme Figuras 4,5 e 6.

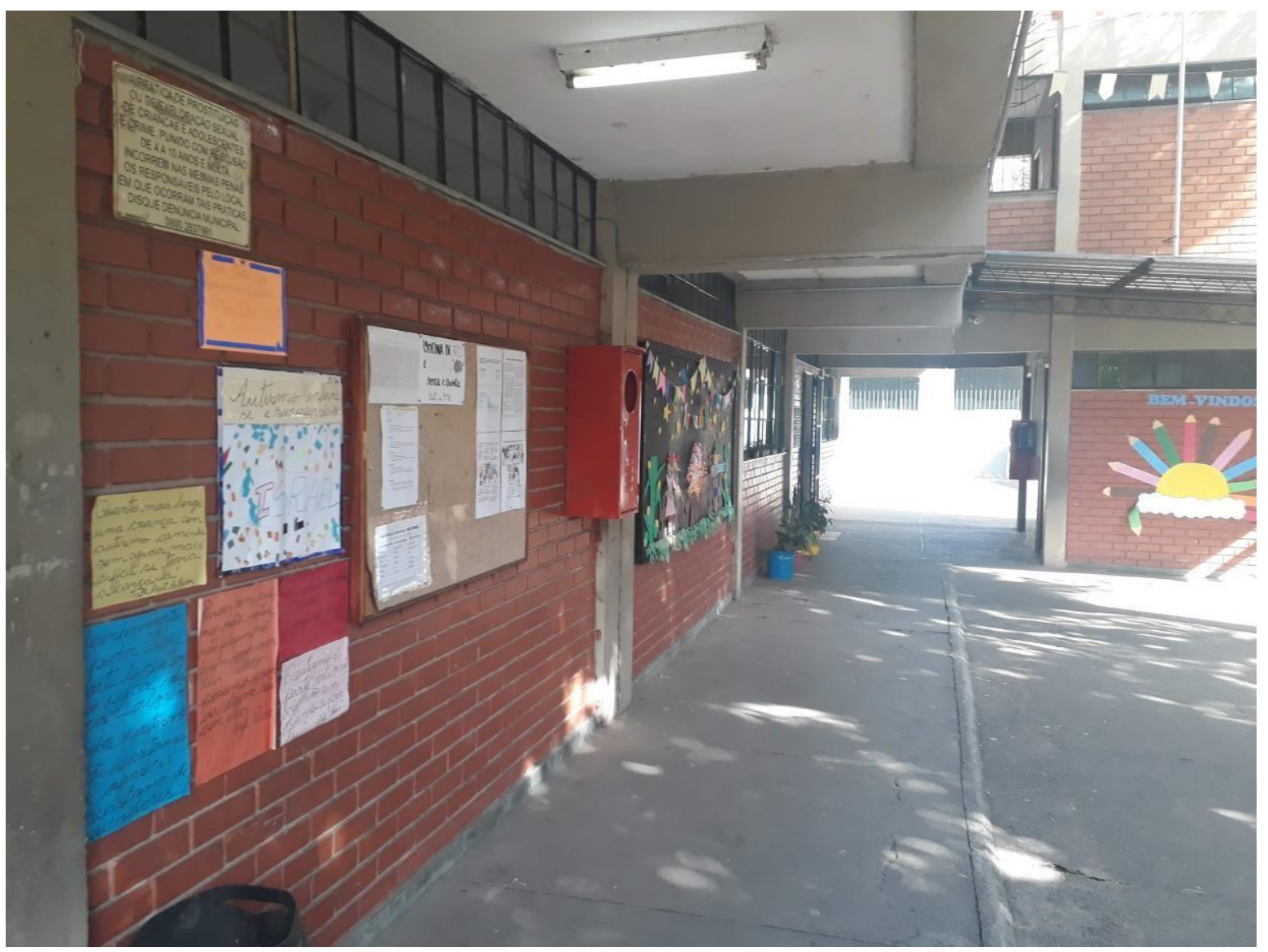

Figura 1 - Escola Travessia - pavimento térreo Fonte: Arquivo pessoal da autora, 2019.

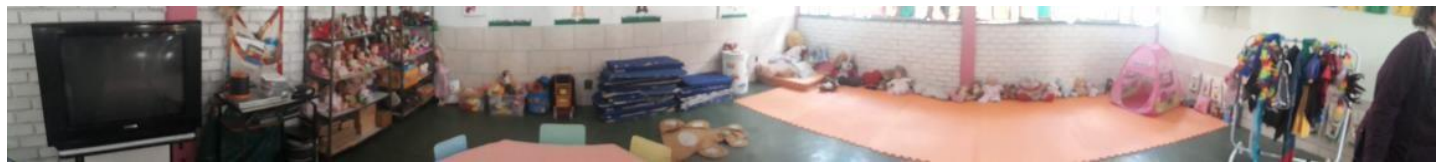

Figura 2 - Vista panorâmica da Brinquedoteca Fonte: Arquivo pessoal da autora, 2019. 


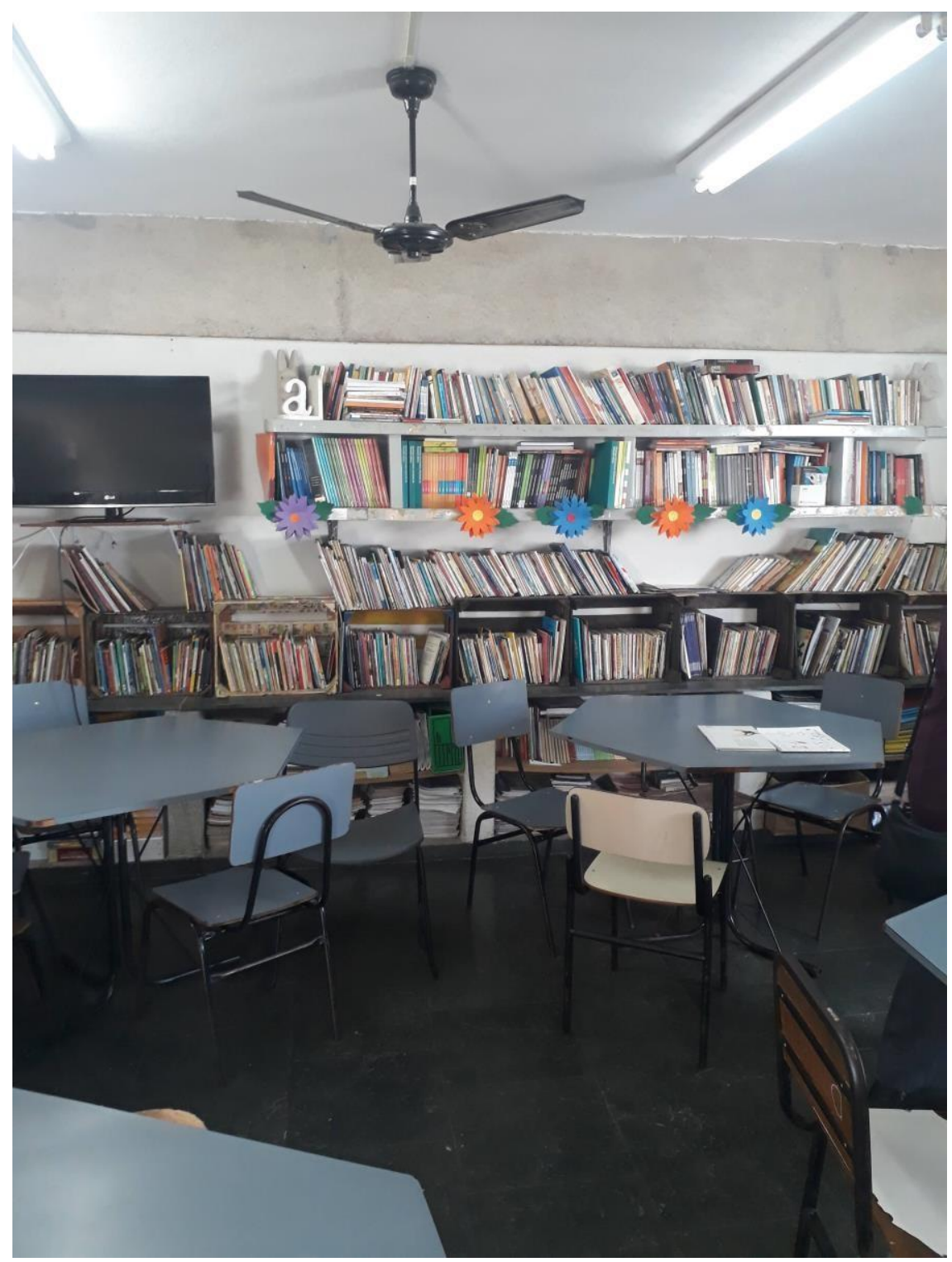

Figura 3 - Biblioteca

Fonte: Arquivo pessoal da autora, 2019.

Em uma construção anexa funciona a secretaria, o laboratório de ciências, o grêmio estudantil e o laboratório de informática no andar térreo e no andar de cima fica uma sala de aula. Na frente desta construção fica a quadra, conforme as Figuras 7, 8 e 9. 


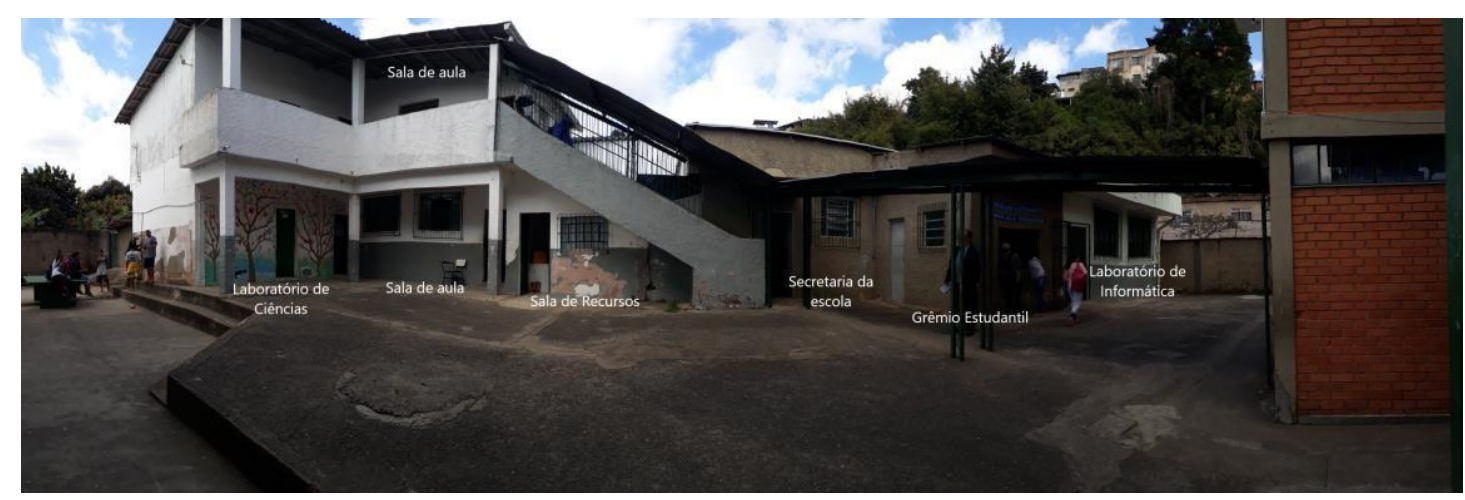

Figura 4 - Vista panorâmica do prédio anexo Fonte: Arquivo pessoal da autora, 2019.

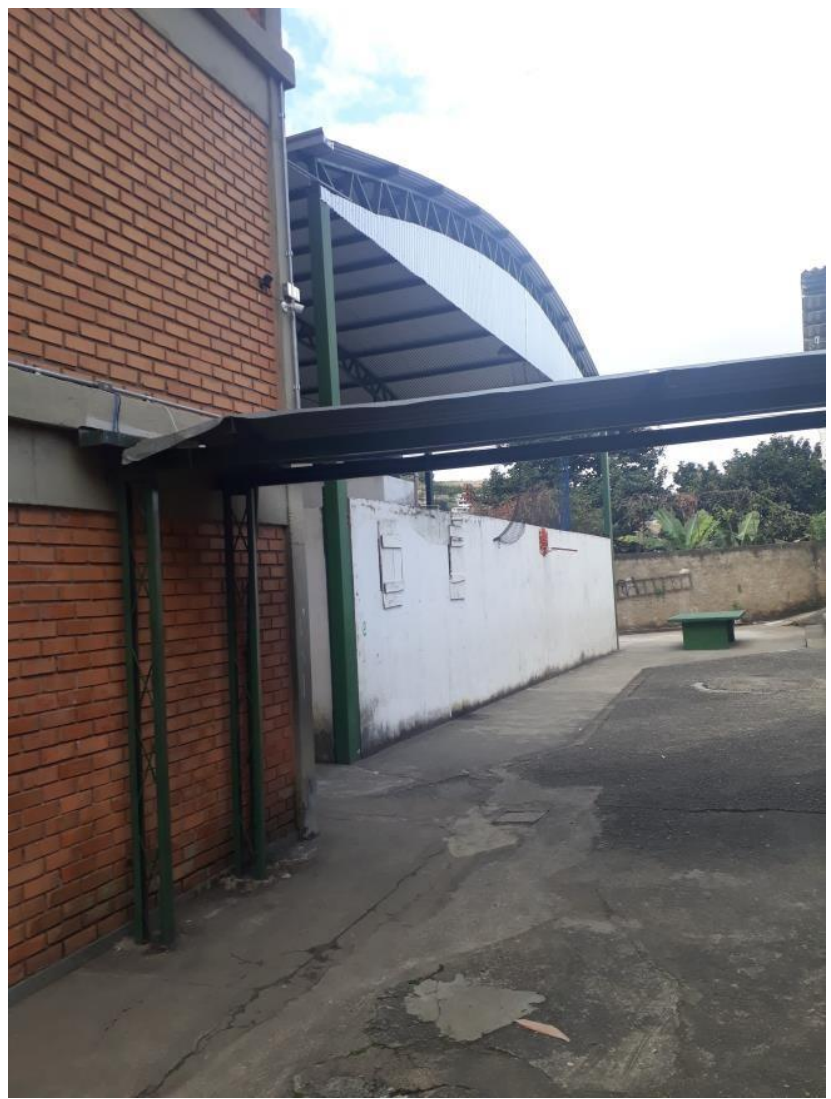

Figura 5 - Quadra em frente ao prédio anexo Fonte: Arquivo pessoal da autora, 2019.

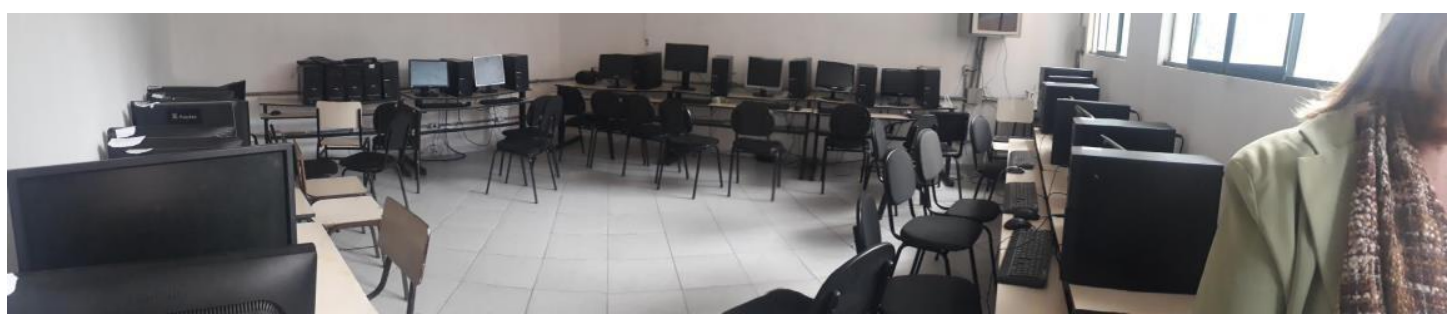

Figura 6 - Laboratório de Informática Fonte: Arquivo pessoal da autora, 2019. 


\section{APÊNDICE C - Fotos da escola Jardim Botânico}

A escola possui uma construção em forma de $U$ com dois pavimentos e uma quadra construída separadamente. No pavimento inferior fica a secretaria, a sala do diretor, a sala dos professores, duas salas de aula, a biblioteca, o laboratório de informática, a cozinha e 0 refeitório. No pavimento superior há somente salas de aulas. O terreno da escola é grande e conta com um estacionamento para carros e uma horta que fica ao longo da extensão do estacionamento. Além disso, tem também uma quadra de terra que era utilizada antes da construção da quadra coberta. A seguir apresentamos algumas fotos da escola na tentativa de ilustrar a descrição feita.

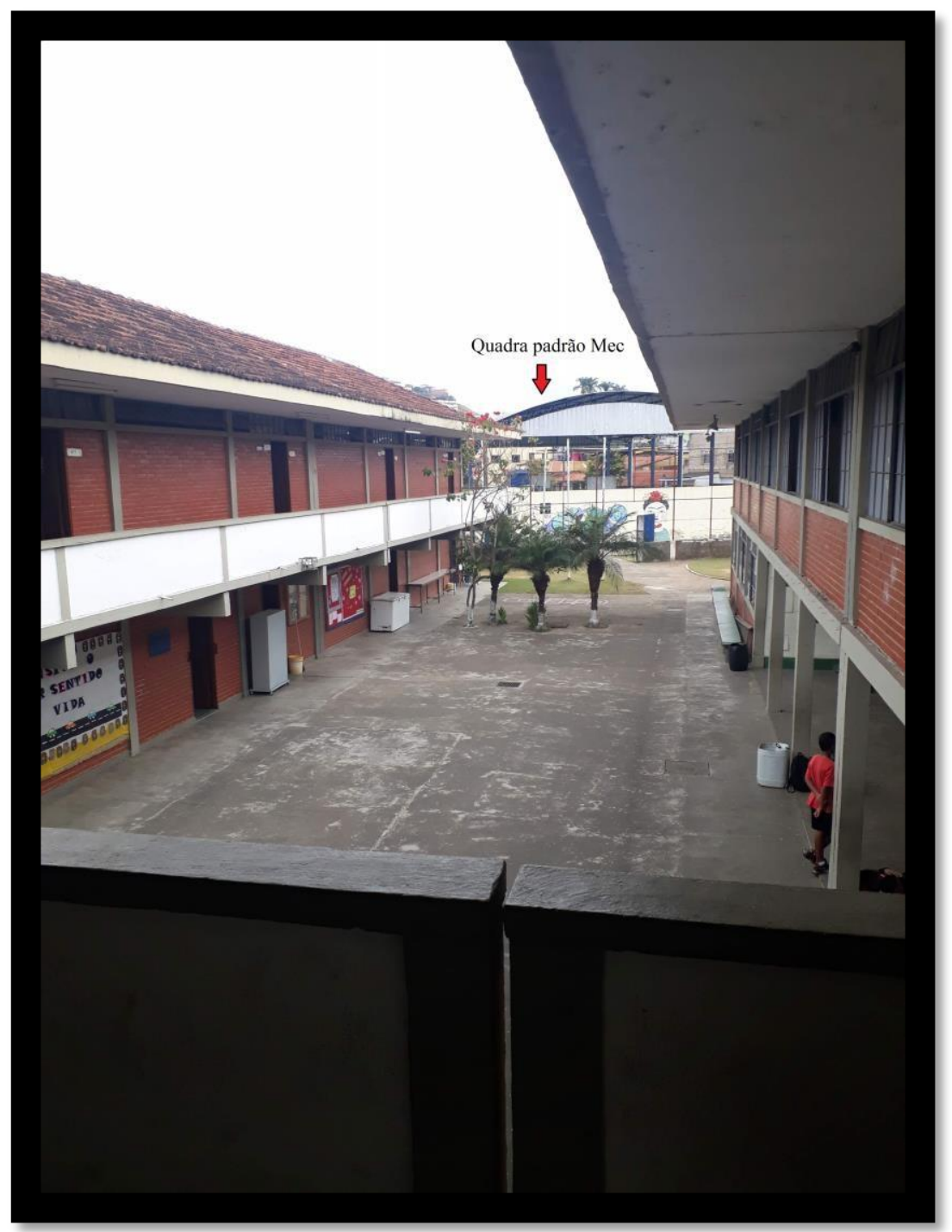

Figura 2 - Foto da Escola Jardim Botânico - estrutura em U com a quadra no fundo Fonte: Arquivo pessoal da autora, 2019. 


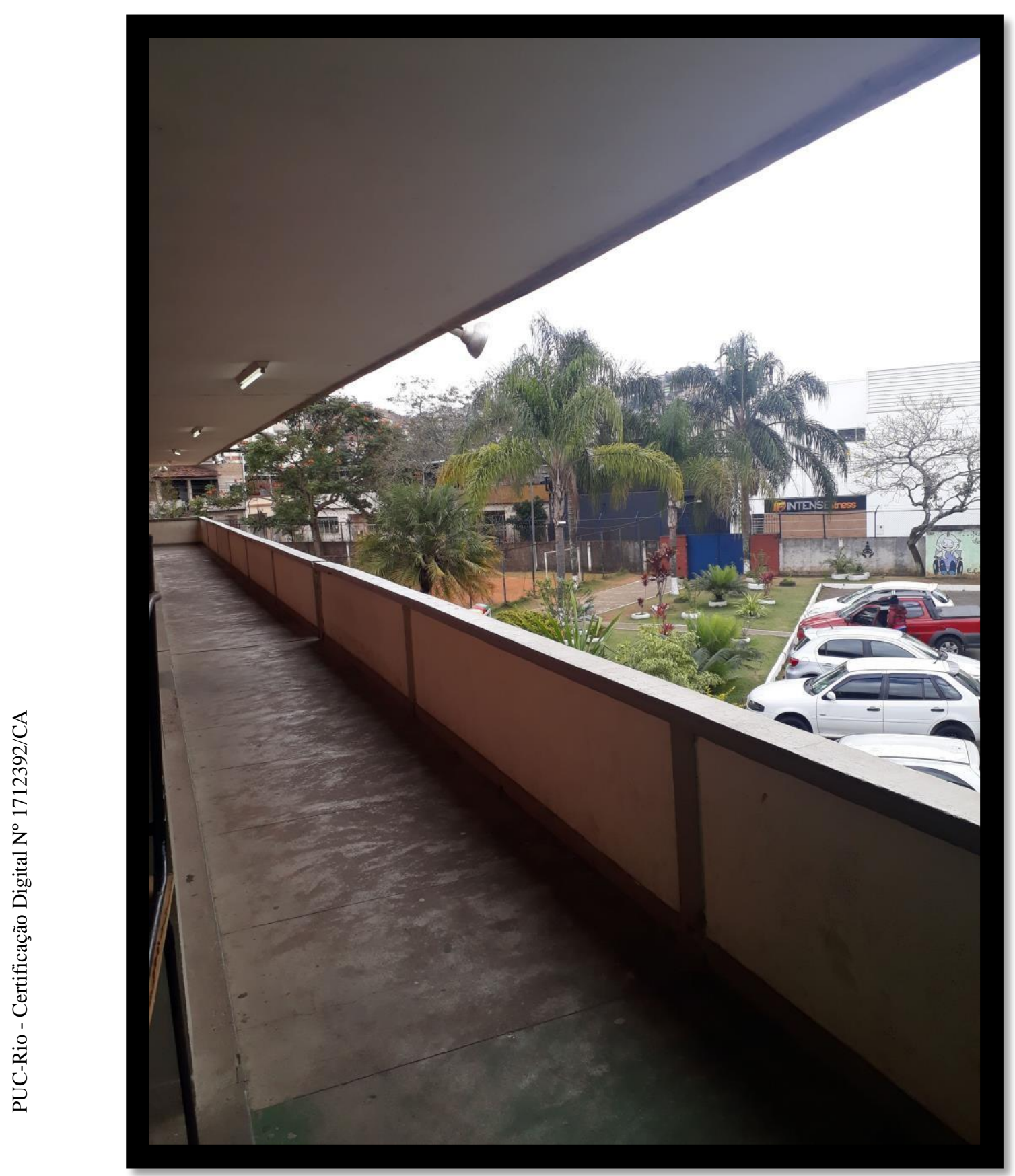

Figura 3 - Foto lateral direita da Escola Jardim Botânico - estacionamento e quadra de terra ao fundo

Fonte: Arquivo pessoal da autora, 2019. 


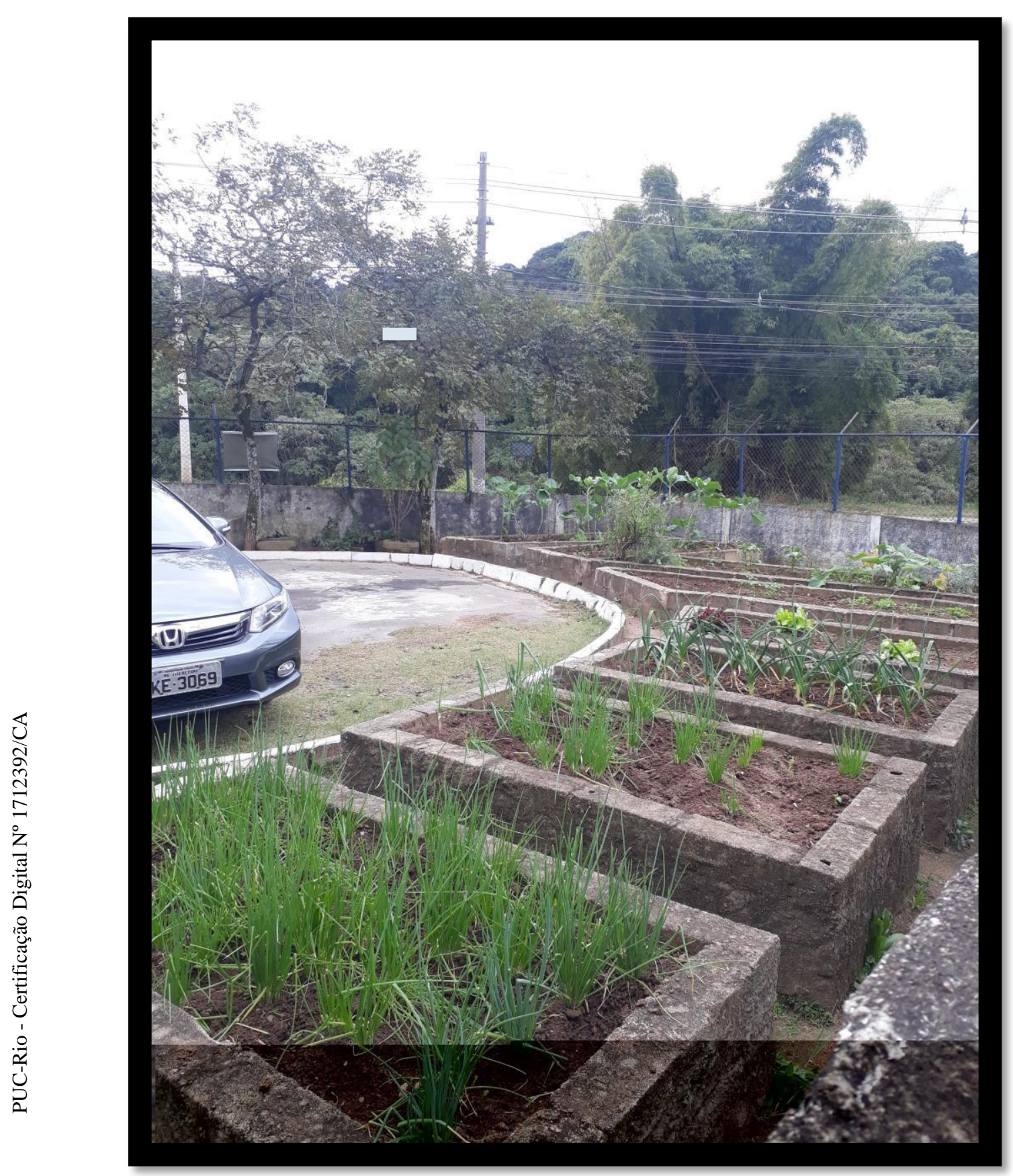

Figura 3 - Foto da horta na Escola Jardim Botânico Fonte: Arquivo pessoal da autora, 2019. 